NBER WORKING PAPER SERIES

\title{
DYNAMISM DIMINISHED: \\ THE ROLE OF HOUSING MARKETS AND CREDIT CONDITIONS
}

\author{
Steven J. Davis \\ John C. Haltiwanger \\ Working Paper 25466 \\ http://www.nber.org/papers/w25466 \\ NATIONAL BUREAU OF ECONOMIC RESEARCH \\ 1050 Massachusetts Avenue \\ Cambridge, MA 02138 \\ January 2019, Revised December 2021
}

We thank Simon Gilchrist, John Robertson and participants in seminars and conferences at the American Economic Association, Bank of Korea, Cambridge University, Congressional Budget Office, Federal Reserve Bank of Atlanta, Goldman Sachs Global Markets Institute, Hoover Institution, London School of Economics, National Bureau of Economic Research, National University of Singapore, Stanford University and the University of Chicago for many helpful comments. Diyue Guo, Lea Rendell and Laura Zhao provided superb research assistance. We gratefully acknowledge financial support from the Goldman Sachs Global Markets Initiative and the Ewing Marion Kauffman Foundation. The views expressed herein are those of the authors and do not necessarily reflect the views of the National Bureau of Economic Research.

At least one co-author has disclosed additional relationships of potential relevance for this research. Further information is available online at http://www.nber.org/papers/w25466.ack

NBER working papers are circulated for discussion and comment purposes. They have not been peer-reviewed or been subject to the review by the NBER Board of Directors that accompanies official NBER publications.

(C) 2019 by Steven J. Davis and John C. Haltiwanger. All rights reserved. Short sections of text, not to exceed two paragraphs, may be quoted without explicit permission provided that full credit, including $\odot$ notice, is given to the source. 
Dynamism Diminished: The Role of Housing Markets and Credit Conditions

Steven J. Davis and John C. Haltiwanger

NBER Working Paper No. 25466

January 2019, Revised December 2021

JEL No. E2,E3,E5,G2,J2

\section{ABSTRACT}

We estimate the effects of house price changes on young-firm employment shares and industrylevel employment growth in local economies. A novel test shows that house price effects on local economies work through wealth, liquidity and collateral effects on the propensity to start new firms and expand young ones. Aggregating local effects to the national level, our estimates imply that housing market ups and downs play a major role - as transmission channel and driving force - in medium-run fluctuations in young-firm employment shares in recent decades. We also find a distinct and smaller role for locally exogenous loan-supply shifts.

Steven J. Davis

Booth School of Business

The University of Chicago

5807 South Woodlawn Avenue

Chicago, IL 60637

and NBER

Steven.Davis@ChicagoBooth.edu

John C. Haltiwanger

Department of Economics

University of Maryland

College Park, MD 20742

and NBER

haltiwan@econ.umd.edu 


\section{Introduction}

Workers at young firms - less than 72 months since first paid employee - fell from 19.7 percent of private sector employees in 1989 to 10.4 percent in 2018 (Figure 1). This pronounced shift away from young firms is part of a broader secular decline in business formation rates, business volatility, the pace of job reallocation, and worker mobility rates in the United States. ${ }^{1}$ Overlaying these long-term developments, the growth rate of the young-firm activity share varies cyclically, as seen in Figure 2. Each bar shows the annual log change in the young-firm employment share, deviated about the mean annual change from 1981 to 2018. The young-firm share falls relative to trend in aggregate contractions and rises or falls more slowly in expansions. The early 1990s and the Great Recession involve the worst relative performance for young firms over the almost 40 years covered by the data.

In light of these observations, we investigate three related questions: First, what is the role of housing market developments, especially the massive boom and bust since the late 1990s, in the fortunes of younger firms? Second, what is the role of credit market conditions? Third, how do young-firm fortunes compare to those of small firms in these respects? To address these questions, we exploit an abundance of spatial and time-series variation in local housing market and credit conditions in the United States. Our main goal is to better understand the cyclical and medium-run fluctuations in the performance and activity shares of young firms. ${ }^{2}$ We estimate the causal effects of local house price changes on local young-firm activity and develop evidence on the channels through which housing prices affect young firms and local economies. We also quantify the role of house price changes and bank loan supply shocks in the national and local fluctuations of young-firm activity shares. Finally, we compare and contrast the implications of house prices and financial conditions for young firms relative to small ones.

Section II describes our data sources for local young-firm activity measures, housing prices, housing supply elasticities, credit supply shifts, and cyclical conditions at the aggregate and local levels. Section III first expands on our characterization of trend and cycle movements

\footnotetext{
${ }^{1}$ These secular developments are well documented in recent work and the subject of active study. See Davis et al. (2007), Davis et al. (2010), Davis, Faberman and Haltiwanger (2012), Fujita (2012), Lazear and Spletzer (2012), Hyatt and Spletzer (2013), Davis and Haltiwanger (2014), Decker et al. (2014ab), Haltiwanger, Hathaway and Miranda (2014), Hathaway and Litan (2014), Karahan et al. (2015), Molloy et al. (2016) and Pugsley and Şahin (2018).

${ }^{2}$ In contrast, recent work by Davis and Haltiwanger (2014) and Karahan et al. (2015), for example, consider forces behind the long-term shift away from younger firms.
} 
in young-firm activity shares. At the national level, the Great Recession involved an especially large and persistent deterioration in young-firm performance (relative to a declining trend) on multiple margins, including the firm startup rate and the growth rate of young relative to older firms. At the state level, changes in young-firm employment shares covary strongly and positively with local cycle conditions and with the growth rate of local house prices.

Section IV implements an instrumental variables (IV) approach to identify the causal effects of local house price changes on local young-firm activity shares. ${ }^{3}$ Our IV strategy generalizes the approach taken in the highly influential works of Mian and Sufi $(2009,2011$, 2014). They instrument for local housing price responses to national housing market boom and bust episodes using local housing supply elasticities. We instrument local house price changes using the interaction between local housing supply elasticities and year-to-year changes in local cycle indicators. Our approach encompasses a much longer sample period and lets us control for a broader set of potential confounders. Using the housing supply elasticity measures of Saiz (2010) in the construction of our instruments, we estimate that a 10 log-point increase in local real housing prices raises the local young-firm employment share by $3.6 \log$ points. As a robustness check, we also construct instruments using the housing price-sensitivity approach of Guren et. al (2021) and obtain similar results: a 10 log-point increase in local housing prices raises the local young-firm employment share by an estimated 3.0 log points. ${ }^{4}$

One advantage of our approach is that it readily accommodates the inclusion of local loan supply shocks. To that end, we build on Greenstone, Mas and Ngyuen (2020) to isolate exogenous MSA-level shifts in bank loan supply to small and young firms. ${ }^{5}$ The idea here is that large banks differ in their financial fortunes, geographic footprints, and propensities to lend to smaller and younger firms. When a national bank pulls back from lending to smaller and younger firms in a given MSA for reasons other than local economic conditions, it produces a locally

${ }^{3}$ Our focus on activity shares differs from previous work on how local house prices affect the demand for local non-traded goods and services (e.g., Mian and Sufi, 2011), local selfemployment and small-firm employment (e.g., Adelino et al., 2015), and the local pace of job creation and destruction at young firms (e.g., Mehrotra and Sergeyev, 2021). In particular, shocks that affect the level of local activity - but not its allocation between young and mature firms - have no effect on our main outcome measures.

${ }^{4}$ In another robustness check, we adapt Mian and Sufi's approach to our setting and obtain qualitatively similar results. See Appendix D.2.

${ }^{5}$ Other related work, with a focus on the Great Recession period, includes Chodorow-Reich (2014), Burcu et al. (2015), Huang and Stephens (2015) and Siemer (2018). Our strategy for identifying credit supply shocks is closest to that of Greenstone, Mas and Nguyen (2020). 
exogenous drop in loan supply. Consistent with this view, we find that "small" business bank loan supply shocks have statistically significant effects on young-firm activity shares. These effects are sizable in certain episodes, particularly the Great Recession.

We also show that "small" business loan supply shocks have weaker effects on small firms than young ones. Siemer (2019) reaches the same conclusion using different data and an empirical design that exploits industry differences in the role of external financing. In addition, we find weaker effects of housing prices on small firms than young ones. These findings reflect the heterogeneous character of the small-firm population. The bulk of small-firm employment resides in firms that are mature and relatively stable, with little need or desire for credit-fueled expansion. In contrast, young firms are much more volatile and highly prone to up-or-out growth dynamics. ${ }^{6}$ Most young firms are also small. Thus, shocks to the supply of "small" business bank lending have much stronger effects on activity in young firms than in the average small firm.

As we discuss in Section V, housing market conditions can affect young firms and the local economy through a variety of wealth, liquidity, collateral, credit supply and consumption demand channels. That discussion leads us to data and empirical designs that help disentangle these channels. Since many studies find large effects of housing price changes on consumption expenditures, we test whether they affect local economies only through consumption demand. Our test of this view is new and conceptually simple: If house price changes work entirely through consumption demand channels, the local industry growth rate response should be invariant to the age structure of firms in the local industry. A natural alternative to this ageinvariance hypothesis says that the local industry response rises with its young-firm activity share due to wealth, collateral, and liquidity effects of house price changes on the propensity to start a new business or expand a young one. We find overwhelming statistical evidence against the age-invariance hypothesis. The departures from age invariance fit the alternative view and involve large effects on the distribution of employment growth across MSA-industry cells in periods with large housing price movements. In a dynamic extension, we also find that the positive effect of local house prices changes on local industry growth rates is both larger and more persistent in MSA-industry cells with greater young-firm activity shares.

\footnotetext{
${ }^{6}$ For evidence that young age is much more indicative of high growth propensity, while small size is not (conditional on age), see Section 4.2 in Davis and Haltiwanger (1999) and Haltiwanger, Jarmin and Miranda (2013). For evidence on the prevalence of up or out behavior among younger businesses, see Davis et al. (2009) and Haltiwanger et al. (2016).
} 
To quantify the role of housing market developments, Section VI combines local house price changes with their estimated causal effects to obtain implied paths for local young-firm activity shares. We then aggregate to the national level and ask how well the results account for the year-by-year changes in Figure 2. By design, our quantification exercise captures the effects of exogenous house price changes and the role of house prices in transmitting shocks that originate elsewhere. Our exercise incorporates a separate role for exogenous bank loan supply shifts. The results say that housing market ups and downs are a major driver of medium-run fluctuations in young-firm activity shares, especially since the late 1990s. The great housing bust after 2006 largely drove the collapse of young-firm activity shares (relative to a declining trend) during the Great Recession, reinforced by the effects of a contraction in bank loan supply. Shifts in the supply of bank lending also played a material role in certain other episodes - contributing, for example, to the increase (relative to trend) in young-firm activity from 2002 to 2006 and 2016 to 2018 .

\section{Data Sources}

\section{a. Young-Firm Activity Measures}

Fort et al. (2013) and Davis and Haltiwanger (2014) show that spatial and industry variation in job flows, worker flows, and growth differentials by firm size and age provide much scope for analysis and identification. We also exploit data sets that offer variation by firm age, firm size, industry and local area (State or MSA). Our outcome measures derive from administrative records that cover all firms with paid employees. A key advantage of the resulting activity measures is that they are not subject to missing observations or sampling variability, even within narrow geographic and industry cells.

Our analysis of young-firm activity relies heavily on the Census Bureau's Business Dynamic Statistics (BDS), which includes employment statistics by firm size, firm age, state, MSA and industry tabulated from micro data in the Longitudinal Business Database (LBD). ${ }^{7}$ The LBD covers the universe of firms and establishments in the nonfarm business sector with at least one paid employee. Employee counts pertain to the payroll period covering the 12th of March in each year from 1976 to 2018. The LBD includes the location of each establishment and, hence, the distribution of each firm's employment across states and MSAs. While BDS firm-level

\footnotetext{
7 The BDS is a public use database at www.census.gov/ces/dataproducts/bds/index.html.
} 
characteristics pertain to the national firm, the state (MSA) activity measures cover all establishments operating in the state (MSA) for the industry, firm size or firm age group.

For our purposes, it is essential to have a suitable measure of firm age and to consistently track young-firm activity over time. Firm age in the BDS reflects the age of its oldest establishment when the firm first became a legal entity. In turn, establishment age equals the number of years since operations began (as indicated by one or more paid employees) in the establishment's current narrowly defined industry. For a startup business comprised of all new establishments, firm age is initially set to zero. For firms newly created from one or more existing establishments through a merger, spinoff or corporate reorganization, firm age is initially set to the age of its oldest establishment. From that point forward, the firm ages naturally as long as it exists. Simple ownership changes do not trigger a change in firm age, and the BDS concept of business startups reflects new firms with only age-zero establishments. These features of the BDS are a major strength, as they ensure that our young-firm activity measures and their evolution are not distorted by firm restructurings and ownership changes.

For simplicity and brevity, our analysis focuses on two age groups: "young" firms less than six years old (fewer than 72 months), and "mature" firms that are at least six years old. ${ }^{8}$ Using these definitions, the BDS lets us track young- and mature-firm activity measures at the national and state levels in a consistent manner from 1981 to 2018 and from 1992 to 2018 at the MSA level. The BDS reports employment and firm counts as of March in the indicated year and March-to-March changes and growth rates. Appendix A provides more information about the level, change and growth rate statistics in the BDS and how we exploit the data.

\section{b. Local Housing Price and Supply Elasticity Measures}

We measure house price changes using data at the state and MSA levels from the Federal Housing Finance Agency (FHFA). These data are available for the entire 1981-2018 period. As explained below, we seek to isolate local house price movements that are exogenous with respect to local young-firm activity shares by interacting other variables with the Saiz (2010) measure of

\footnotetext{
${ }^{8}$ Davis and Haltiwanger (2019) use an age $<5$ cutoff for young firms that is no longer available in MSA-level BDS data. The age $<5$ and age $<6$ cutoffs yield very similar results for the overlapping periods. Compare, for example, our Table 1 to Table 3 in the earlier draft. Related, the earlier BDS vintage did not offer statistics for the cross product of firm age, industry, and MSA. Thus, we turned to the Quarterly Workforce Indicators (QWI) in the earlier draft for analyses requiring data at that granularity. These BDS- and QWI-based results are also very similar - compare our Tables 6 and 7, for example, to Tables 6 and 7 in the earlier draft.
} 
the local housing supply elasticity. His measure, available at the MSA level, reflects a careful effort to quantify supply elasticities based on detailed studies of local zoning, regulatory and natural topographic and geophysical barriers to residential housing construction. Saiz produces housing supply elasticities for 248 MSAs, for 15 of which we cannot produce all regressors in our empirical specifications on a balanced-panel basis. Thus, we typically report results for samples that contain 233 MSAs, roughly three times as many as in Mian and Sufi (2011). In a robustness check, we use the inverse of MSA-level housing-price sensitivity estimates, following the approach of Guren et al. (2021), instead of the Saiz elasticity measures.

\section{c. Bank Lending Measures}

We follow Greenstone, Mas and Ngyugen (2020) (hereafter GMN) in using data on small business loan activity that banks file in compliance with the Community Re-Investment Act of 1996 (CRA). The CRA requires banks with assets greater than 1 billion to report annually on small business loans at the county level. We aggregate these CRA data to the MSA level. Like GMN, we consider the volume of loans to businesses with less than $\$ 1$ million in gross revenue. We build on the GMN approach to construct local "small" business loan supply shocks using a modified Bartik-like approach, as detailed in Section V below. Although the CRA data explicitly specify loans to small business, we think there is considerable overlap between credit supply shifts for small business lending and credit supply shifts for young business lending. Our empirical results strongly support that view.

When integrating data across sources, we pay careful attention to the timing of the observations. BDS employment data reflect the payroll period covering the 12th day of March in each calendar year. We measure employment changes and changes in all other variables over the same March-to-March intervals. It is straightforward to align the timing for most of our variables, because they are available on a monthly or quarterly basis. The annual CRA data are an exception. Appendix C details how we construct our CRA-based measures.

\section{d. Local and National Cycle Indicators and Other Variables}

We supplement our young-firm activity measures with local and national business cycle indicators. At the state and MSA level, we use unemployment rates from the BLS Local Area Unemployment Statistics (LAUS) program, which draws on data from the Current Population Survey, Current Employment Statistics, claims for unemployment insurance benefits and other sources. We have consistent measures of unemployment rates at the state level from 1980 to 2018 and at the MSA level from 1990 to 2018. We use real GDP growth rates as a national 
business cycle indicator. We obtain annual county-level population data from the Census Bureau, which we map to MSAs as explained in Appendix A. Finally, we rely on the Quarterly Census of Employment and Wages (QCEW) at the national and MSA-industry level (2-digit NAICS) to construct additional controls and instruments for local demand shifts.

\section{Secular, Cyclical, and Spatial Patterns in Young-Firm Activity}

\section{a. Aggregate Measures of Young-Firm Activity}

The patterns depicted in Figures 1 and 2 reflect changes along several margins at young and mature firms. To see this point, write the change from $t-1$ to $t$ in young-firm employment as

$$
E_{t}^{a<6}-E_{t-1}^{a<6}=\left[E_{t}^{0}+\sum_{a=1}^{5}\left(E_{t}^{a}-E_{t-1}^{a-1}\right)\right]-E_{t-1}^{5} \equiv N E T_{t}^{a<6}-E_{t-1}^{5}
$$

where $E_{t}^{a<6}$ is employment in young firms (age<6) in year $t, E_{t}^{0}$ is employment in startup firms (age=0) in $t$, and $E_{t}^{a}$ is employment in firms of age $a$ in $t$. This accounting identity says that the young-firm employment change equals the net change among firms that remain young, inclusive of new employment at startup firms, minus employment at firms that age out of the young group. Similarly, the employment change from $t-1$ to $t$ among mature firms is the net change among the already mature as of $t-1$ plus employment at firms that age into the mature group in $t$. A parallel set of accounting relationships holds for the numbers of young and mature firms.

We express young-firm employment as a share of total private-sector employment. Thus, Figure 1 plots the evolution of $E_{t}^{a<6} / E_{t}$, where $E_{t}$ is the count of all paid employees in the nonfarm private sector in March of year $t$. Figure 2 plots the annual value of $\ln \left(E_{t}^{a<6} / E_{t}\right)-$ $\ln \left(E_{t-1}^{a<6} / E_{t-1}\right)$, deviated about its mean value from 1981 to 2018. Appendix B presents additional evidence on the secular and cyclical behavior of young-firm activity measures, which we summarize here. Figure B1 shows a strong secular decline in the firm startup rate since the mid 1980s, a further large drop in the Great Recession, and little recovery afterwards. The firm exit rate moves counter cyclically with little or no trend. ${ }^{9}$ The net entry rate of firms actually turned negative in the Great Recession for the first time since at least 1981, and it remains modest more recently. These developments translate into a pronounced drop in the share of firms

\footnotetext{
9 The BDS measure of firm exit rates reflect legal entities that shut down all establishments. Like the startup rate, the BDS exit rate concept is designed to abstract from firm ownership changes and M\&A activity.
} 
with paid employees that are less than six years old - from 46 percent in 1981 to 33 percent in 2018 (Figure B2).

Figure B3 reports net growth rates for the employment of young and mature firms, inclusive of entry and exit for each age group. ${ }^{10}$ For changes from $t-1$ to $t$, the BDS classifies establishments into firm age groups based on the parent firm's age at $t$. Young firms exhibit much higher net growth rates than mature firms. This pattern underscores the importance of young firms in the job creation process, as highlighted in Haltiwanger et al. (2013). However, young firms exhibit larger growth rate declines in downturns, especially so in the Great Recession. In fact, the net growth rate of young firms plummeted from 22 percent in 2006 to 5 percent in 2009, a dramatic negative swing of 17 percentage points. In contrast, the employment growth rate of mature firms fell from one percent in 2006 to minus 7 percent in 2009.

Appendix B also presents analogs to Figure 2 for other young-firm activity measures. Figure B4 shows that the early 1980s and the Great Recession saw especially large declines relative to trend in the young-firm share of firms with paid employees. Figure B5 shows that the net employment growth rate of young firms saw especially large declines relative to mature firms in the 1990-91 downturn and in the Great Recession. It's worth stressing that the Great Recession involved an historic deterioration in young-firm performance for all of the activity measures we consider. In what follows, we focus on the young-firm employment share, but Figures B1-B5 make clear that secular declines and procyclical movements in young-firm performance are present on several margins.

\section{b. State-Level Fluctuations in Young-Firm Employment Shares}

To help motivate our attention to the drivers of fluctuations in young-firm activity, Figure 3A presents a bin scatter of log differences in young-firm employment shares against changes in the unemployment rate at the state-year level from 1981 to 2018. (Appendix Figure B6A shows a scatter of the raw data.) There is much state-level time-series variation in these measures, which we will use in our econometric investigation. An increase in the state-level unemployment rate of one percentage point is associated with a drop of nearly one log point in the state-level youngfirm employment share. Figure 3B shows the contemporaneous relationship of log differences in

\footnotetext{
10 The BDS follows Davis, Haltiwanger and Schuh (1996) in calculating group-level growth rates as the employment weighted mean of establishment-level growth rates in the group, where each establishment's growth rate is measured as its change from $t-1$ to $t$ divided by the simple mean of its employment in $t-1$ and $t$.
} 
the young-firm employment share to log differences in real housing prices at the state-year level from 1981 to 2018. (Appendix Figure B6B shows a scatter of the raw data.) A real house price gain of $10 \log$ points in a state is associated with an increase in its young-firm employment share of $2 \log$ points, with a $t$-statistic of about 5. Appendix Figures B6C and B6D show that greater house price appreciation in a state also coincides with a larger rise (or smaller fall) in the youngfirm share of all firms with paid employees and in the firm startup rate.

Figure 3B might appear at odds with results in Hurst and Lusardi (2004). Using data from the Panel Study of Income Dynamics (PSID) and regional house price variation from 1985 to 1988, they test whether households in Census regions with strong house price gains were as unlikely to start a business as households in other regions. They do not reject this hypothesis. Restricting our state-level panel data to the 1985-1988 period considered by Hurst and Lusardi, and rerunning our Figure 3B regression, yields an estimated coefficient of 0.20 (0.06). So different sample periods do not explain our different results. Instead, we think our results differ from theirs because of important conceptual and measurement differences. First, business starts in the PSID include those with no employees, while our measures consider only firms with paid employees. Davis et. al. (2009) show that non-employer businesses are much more numerous than employer businesses, but most non-employer businesses are very small, contribute little to aggregate economic activity, and are unlikely to ever hire a worker. Second, our use of administrative data sources yields much more precise estimates of young-firm activity in narrower geographic areas, affording a greater capacity to detect statistical associations.

In summary, Figures $3 \mathrm{~A}$ and $3 \mathrm{~B}$ tell us that stronger state-level economic conditions and rising house prices involve an increase in the state's share of economic activity at young firms. Of course, these empirical relationships do not tell us why young-firm activity shares covary strongly with local conditions, but they suggest the possibility that housing market developments have important causal effects on young-firm activity. Hurst and Stafford (2004), Mian and Sufi (2011), Mian, Sufi and Trebbi (2015) and Agarwal et al. (2020), among others, find evidence that house price gains stimulate household spending and local economic activity more generally.

\section{Local Effects of Housing Prices and Loan Supply on Young-Firm Activity a. Overview of Estimation and Identification}

We implement an instrumental variables (IV) approach to identify the causal effects of local house price changes on local young-firm activity shares. Specifically, we construct 
instruments for local house price changes by interacting local housing supply elasticities from Saiz (2010) with time-varying measures of local economic conditions. Our approach is similar in spirit to that of Mian and Sufi (2011) but permits a much larger sample size and facilitates the inclusion of loan supply shocks. Our approach also differs from Mian and Sufi (2011) in its focus on young-firm activity shares and in our use of panel data to control for unobserved factors that affect local MSA trends.

\section{b. Panel Regression Specifications and Instruments}

We estimate IV regression models of the following form:

$$
\begin{array}{ll}
Y_{m t}=\sum_{t} \lambda_{t} I_{t}+\sum_{m} \lambda_{m} I_{m}+\beta H P_{m t}+\alpha C Y C_{m t}+X_{m t}^{\prime} \theta+\varepsilon_{m t} & \text { (1) (Second stage) } \\
H P_{m t}=\sum_{m} \delta_{m} I_{m}+\sum_{s} \delta_{t} I_{t}+C Y C_{m t} Z_{m}^{\prime} \gamma+\pi C Y C_{m t}+X_{m t}^{\prime} \phi+\eta_{m t} & \text { (2) (First stage) }
\end{array}
$$

where $Y_{m t}$ is the log change from year $t-1$ to $t$ in the young-firm share for MSA $m ; H P_{m t}$ is the contemporaneous log change in the MSA's house price index; $I_{t}$ and $I_{m}$ are dummy variables for years and MSAs, respectively; the $\lambda$ 's and $\delta$ 's are corresponding coefficients, $C Y C_{m t}$ is the contemporaneous change in the MSA-level unemployment rate; the $X_{m t}$ are additional controls that vary at the MSA-year level; $Z_{m}$ is a cubic polynomial in the housing supply elasticity; and $\gamma$ is a conformable vector of coefficients. The chief parameter of interest is $\beta$, our estimate of how the change in the local young-firm employment share responds to a local house price change.

To identify $\beta$ we rely on the exclusion restrictions, $E\left(C Y C_{m t} Z_{m}^{\prime}, \varepsilon_{m t}\right)=0$. That is, identification rests on the assumption that the interaction between the local cycle and local supply elasticity affects $Y_{m t}$ only through its effect on local house price growth, $H P_{m t}$, conditional on controls.

We introduce $Z_{m}$ as a cubic polynomial in the first-stage regression, because the data provide clear evidence that house price responses to cyclical conditions vary nonlinearly with the local housing supply elasticity. Indeed, the $\gamma$ coefficients on the linear, quadratic, and cubic terms are statistically significant in our first-stage specifications, as reported in Table B.1. Moreover, we cannot reject the null of instrument validity in overidentification tests reported in Table 1 below. Finally, MSA-level house price changes during the national housing boom (1998 to 2006) and bust (2008 to 2010) episodes also vary nonlinearly with housing supply elasticities. In particular, house price changes tend to be larger in magnitude for MSAs with lower supply elasticities, as measured by Saiz (2010). See Appendix Figures B.7A and B.7B. 


\section{c. Potential Threats to Identification}

Given our choice of dependent variable in (2), reverse causality is not a serious threat to identification. That is, we do not think exogenous shifts in the local young-firm share of activity drive changes in local house price growth. A more serious concern is that (1) and (2) may not adequately control for local shocks that affect our second-stage outcome measure, $Y_{m t}$, through channels other than local house price growth. To address this concern, we include several types of controls. First, we control for a local demand shifter that varies by MSA and year, which we construct as (the lagged MSA-level industry employment share) times (the current-period national industry employment growth) summed over 2-digit NAICS industries. ${ }^{11}$ This variable serves to control for local demand shifts that might drive both local housing prices and the local young-firm activity share. Second, we control for the average annualized growth rate in the MSA-level population during the period, using data from the Bureau of the Census. This variable controls for the possibility that an inflow of new residents drives up local house prices and the young-firm activity share. Finally, our panel regression approach lets us control for year effects and MSA-specific factors, addressing concerns about other forces that happen to correlate with local housing supply elasticities, as argued by Davidoff (2016).

\section{d. Estimated Effects of Local House Price Changes}

Figure 4 displays a scatter plot of the annual MSA-level changes in young-firm employment shares and house prices that we use in estimating (1) and (2), with data points colorcoded by subperiods. (Appendix Figure B8 displays the corresponding bin scatter.) During the boom period from 1998 to 2006, housing prices rose sharply, with gains in most MSAs. During the bust period from 2007 to 2010, housing prices fell sharply in most MSAs. Both periods show huge local variation and a strong positive relationship across MSAs between changes in housing prices and young-firm employment shares. The relationship is also robust to excluding the national boom and bust periods. Restricting attention to the 1992-97 and 2011-18 periods in Figure 4 yields a slope coefficient of 0.27 , with a standard error of 0.03 .

Table 1 reports estimates for $\beta$, the chief parameter of interest in (1). According to Column (5), which entails the fullest set of controls, an annual increase in local real housing prices of $10 \log$ points raises the local young-firm employment share by 3.57 log points. The IV

\footnotetext{
${ }^{11}$ We use annual QCEW data to construct this Bartik-type measure. Results are similar using 4digit industry data, but there is much cell-level data suppression at that level of disaggregation.
} 
estimates of $\beta$ are considerably larger than the OLS estimates, in line with the view that local housing price indices contain substantial measurement error.

In a robustness check, we drop the Saiz measure and follow the approach of Guren et al. (2021) to estimate local house-price sensitivities. Their idea is to estimate MSA-level housing price responses to broad housing demand shifts in a larger region that encompasses the MSA. As in their "refined" approach, we control for various local and regional effects when estimating the MSA-level price sensitivities. See Appendix D.1 for details. As Guren et al. discuss, the resulting price-sensitivity estimates are interpretable as the inverse of MSA-level housing supply elasticities. Thus, we use the inverse MSA price-sensitivity estimates to construct our instruments, interacting with local cycle indicators as before. This alternative approach to instrumenting for MSA-level house price growth rates yields similar results, as reported in Column (6) of Table 1: an increase in local real housing prices of $10 \mathrm{log}$ points raises the local young-firm employment share by an estimated $2.96 \log$ points. ${ }^{12}$

In another check, we more closely follow Mian and Sufi by collapsing the data into one MSA-level observation per period for pre-boom, boom, bust, and post-bust periods. We instrument for MSA-level house price growth rates by interacting period effects with a cubic polynomial in the Saiz elasticity, while controlling for period effects, MSA effects, and variables that vary at the MSA-period level. We again find that local house price growth has large, positive, statistically significant effects on young-firm employment shares. See Appendix D.2.

\section{e. Adding Small Business Lending Shocks}

We now extend (1) and (2) to incorporate a role for "small" business loan supply shocks as potential drivers of young-firm activity shares. Our aim is to estimate the role of shifts in bank loan supply to small and young firms due to forces that are exogenous to local economic activity. We follow the approach of GMN (2020), who exploit the fact that national and regional banks differ in their financial fortunes and their geographic footprints. To see the basic idea, suppose bank B with a large local footprint reduces its lending to small and young firms nationally for reasons unrelated to local conditions. Bank B's pullback in local lending to young firms reduces their credit access, assuming alternative sources of credit supply are less than perfectly elastic.

\footnotetext{
${ }^{12}$ We use a quadratic polynomial in the inverse price-sensitivities, interacted with the local cycle control in this robustness check. Using a cubic polynomial yields similar second-stage results, but the cubic term in the first stage is not significant.
} 
To operationalize this idea and construct local loan supply shocks, we use CRA data on the volume of individual bank lending to small businesses in each MSA. ${ }^{13}$ For every pair of consecutive years, we first fit the following regression by weighted least squares:

$$
g_{m j t}=M S A_{m t}+\text { Bank }_{j t}+\varepsilon_{i j t}
$$

where $g_{m j t}$ is the growth rate in the real volume of small business loans by bank holding company $j$ in MSA $m$ from $t-1$ to $t$, and we weight by the bank's volume of small business loans in MSA $m$ in $t-1$. The MSA effects control for local conditions, and the Bank effects capture the national growth of small business lending by the bank holding company (hereafter, "bank").

Next, to estimate the locally exogenous component of the growth rate in small business bank lending to MSA $m$, we construct a Bartik-like measure given by:

$$
S B L_{m t}=\sum_{j} \omega_{m j t-1} \widehat{B a n k}_{j t}
$$

where $\omega_{m j, t-1}$ is bank j's share of small business lending in MSA $m$ at $t-1$. SBL captures crossMSA variation in small business lending by the national banks that differ in their fortunes and in the geographic footprints of their small business lending activity. We treat this measure as exogenous to local young-firm employment shares.

Incorporating small business loan supply shocks, our statistical model becomes

$Y_{m t}=\sum_{t} \lambda_{t} I_{t}+\sum_{m} \lambda_{m} I_{m}+\beta H P_{m t}+\alpha C Y C_{m t}+\varphi S B L_{m t}+X_{m t}^{\prime} \theta+\varepsilon_{m t}$

$H P_{m t}=\sum_{m} \delta_{m} I_{m}+\sum_{s} \delta_{t} I_{t}+C Y C_{m t} Z_{m}^{\prime} \gamma+\pi C Y C_{m t}+\chi S B L_{m t}+X_{m t}^{\prime} \phi+\eta_{m t}$

Because our SBL data run only from 1999 to 2018, we lose the ability to control for year effects in an unrestricted manner while retaining enough power to recover precise estimates for the key parameters. Thus, we drop the year effects and instead introduce a quadratic polynomial in national GDP growth rates in the $X$ vector.

Table 2 reports OLS and IV estimates of the key parameters in (5). We find positive, statistically significant effects of local bank loan supply shocks on local young-firm activity shares. An increase in the loan supply shock of $10 \log$ points raises the local young-firm employment share by 0.14 to $0.16 \log$ points in the IV specifications and 0.20 in the $\operatorname{IV}(\mathrm{S})$ specification. The estimated effects of local housing price changes in Table 2 are similar to the

${ }^{13}$ See Appendix $\mathrm{C}$ for more information about the CRA data and how we use them. 
ones in Table 1, despite the shorter sample period and inclusion of loan supply shocks. The evidence that bank loan supply shocks matter for young-firm activity shares is weaker than the evidence that housing price growth matters.

\section{f. Results for the Employment Growth Rate as Dependent Variable}

By treating the young-firm employment share as the dependent variable, the specifications in Tables 1 and 2 control for omitted variables that have equiproportional effects on the activity levels of young and mature firms. This specification feature is attractive from an identification standpoint, but we are also interested in effects on employment growth. To that end, Table 3 reconsiders the statistical model (5) and (6) but treats MSA-level growth rates in the employment of young and mature firms as dependent variables. According to the IV results in Panel A, an increase in local housing prices of $10 \log$ points raises local young-firm employment by 3.8 to $4.1 \log$ points. Panel B, in contrast, shows a much smaller effect on mature-firm employment that is statistically insignificant when including our full battery of controls. Loan supply shocks also have much larger effects on young-firm than mature-firm employment. In short, Table 3 says that house price changes and loan supply shocks cause large percentage changes in the activity levels of young firms but much smaller, mostly statistically insignificant, effects on mature firms.

\section{g. Small-Firm and Young-Firm Effects Compared}

Thus far, we have focused on how housing market conditions and bank loan supply affect young-firm activity. Young firms also tend to be small. Moreover, as discussed in Gertler and Gilchrist (1994) and Fort et al. (2013), firm size often serves as a proxy for access to credit markets. A natural question then is whether our main findings hold for small firms as well as young ones. The short answer is yes, but the effects on small firms are considerably weaker and not always statistically significant.

For present purposes, we define small firms as those with fewer than 20 paid employees. ${ }^{14}$ Using this threshold, the small-firm share of private-sector employees fell from 22 percent in 1981 to 17 percent in 2018 (Figure 5). This aspect of small-firm behavior mirrors, in muted form, the secular fall in young-firm shares. However, unlike the pattern documented in Figure 2, the small-firm employment share moves counter cyclically (Figure 6). An important reason for

\footnotetext{
${ }^{14}$ In an earlier draft, we use a 50-employee threshold, which is not available at the MSA level in the new BDS. Appendix B shows that our results are robust to using a 100-employee threshold. See Figures B12 to B14.
} 
this dynamic pattern is that many firms slip below the small-large threshold in contractions and rise above it during expansions (Davis, Haltiwanger and Schuh, 1994 and 1996).

In Table 4, we compare the results of estimating (5) and (6) with the small-firm share as the dependent variable to results for the young-firm share. Whether we run OLS or IV, the estimated effects of local housing price growth are more than twice as large on young-firm shares as on small-firm shares. The same pattern holds for the estimated effects of small business bank loan supply shocks. That is, "small" business bank loan supply shocks have much larger estimated effects on young-firm shares than on small-firm shares.

Given the threshold-crossing issue, we also conduct the small-versus-young comparison using a different dependent variable. Accordingly, Table 5 reports the results of estimating (5) and (6) for the growth rate differential between small firms and large ones, where we classify each firm into a given size bin for $t-1$ and $t$ based on its size in $t$. This approach follows Davis and Haltiwanger (1999) and Fort et al. (2013). Table 5 also reports results of estimating (5) and (6) for the growth rate differential between young and mature firms. Local house price changes have substantially larger effects on the young-mature employment growth differential than on the small-large differential. We also find strong statistical evidence that local small business loan supply shocks affect young-mature net growth rate differentials but no statistically discernable effect on local small-large growth-rate differentials.

We interpret these results as evidence that young firms in particular, rather than small firms in general, are especially sensitive to credit availability. As discussed in Gertler and Gilchrist (1994), the informational frictions that raise external financing costs pertain to young firms more than small ones. Young firms are also more dynamic, and more likely to bump up against credit restrictions that constrain their growth. Most mature small firms, in contrast, have little prospect for rapid growth regardless of credit availability.

\section{Transmission Channels and the Age-Invariance Proposition}

\section{a. From House Prices and Credit Supply to Young-Firm Activity}

Local housing market conditions can affect young-firm activity and the local economy through a variety of wealth, liquidity, collateral, credit supply, and consumption demand channels. Independent of local housing market conditions, other local and national developments can shift the supply of credit that young firms tap to finance their activities. 
Empirically, Robb and Robinson (2012) show that young firms finance their activities using home equity loans, personal loans, bank loans, and personal wealth.

Much previous research finds a positive empirical relationship between personal wealth and the propensity to start or own a business. Examples include Evans and Jovanovic (1989), Holtz-Eakin et al. (1994), Gentry and Hubbard (2004) and Hurst and Lusardi (2004). Empirical studies that specifically consider the impact of changes in home equity values on the propensity to become self-employed or otherwise start a business include Black et al. (1996), Fan and White (2003), Fairlie and Krashinsky (2012), Adelino et al. (2015), Schmalz, Sraer and Thesmar (2015), and Harding and Rosenthal (2017). Jensen et al. (2021) exploit high-quality Danish micro data and a legal change in 1992 that, for the first time, allowed home equity to serve as collateral in bank loans to finance consumption expenditures or business investment. This exogenous relaxation of collateral constraints led to an increase in new business formation, more so for households that experienced larger increases in usable collateral.

We turn now to a discussion of several channels through which house price changes and credit supply shifts can affect business startup rates and young-firm activity shares.

Wealth Effects on Business Formation and Expansion

A classic paper by Khilstrom and Laffont (1979) models the choice between operating a risky firm and working for a riskless wage in general equilibrium. Individuals in their model differ in absolute risk aversion levels. The least risk-averse individuals become entrepreneurs, and the rest choose to be workers. Under certain regularity conditions, greater risk tolerances in the population lead to a greater number of entrepreneurs in equilibrium and higher wages. While Khilstrom and Laffont do not model the determinants of risk aversion, a time-honored view holds that absolute risk tolerance rises with wealth. Guiso and Paiella (2008) provide evidence. Thus, by raising wealth levels, a local house price boom increases risk tolerances among local homeowners and thereby stimulates new firm formation.

If existing young-firm owners face a similar tradeoff between less risky (stay small) and more risky (become larger) undertakings, wealth gains among existing young-firm owners lead to increases in their business activity levels. Kihlstrom and Laffont describe conditions that ensure more risk-tolerant entrepreneurs run larger firms. Thus, insofar as many young-firm owners also own homes, a housing price boom (bust) will lead to an expansion (contraction) in young-firm activity levels. Of course, this mechanism also applies to homeowners who own mature firms. We think local young-firm activity levels are likely to exhibit a larger proportional 
response to local house price growth for two reasons: young-firm owners are more likely to own a home in the same area as their businesses, and home equity is likely to form a larger share of overall wealth for young-firm owners as compared to mature-firm owners.

In short, the entrepreneurial choice model of Khilstrom and Laffont, plus standard views about wealth and risk tolerance, imply that local house price booms (busts) cause an upturn (downturn) in the local firm startup rate and in the local young-firm activity share. The latter implication also rests on an auxiliary assumption of greater proportional responses to local house price changes among young-firm owners.

Wealth effects on young-firm activity shares can also arise for other reasons. Hurst and Pugsley (2017) focus on the non-pecuniary benefits of business ownership such as "wanting to be my own boss" and "wanting to pursue my passion." They model the non-pecuniary benefits of business ownership as separable from the utility of other consumption goods. Thus, as wealth rises and the marginal utility of other consumption falls, households become more inclined to indulge their tastes for business ownership. Effectively, owning a business is a normal good, the demand for which rises with wealth. If local house price gains (losses) lead to higher (lower) expenditures on other consumption goods, then housing booms (busts) nudge additional households into (out of) business ownership.

The Hurst-Pugsley mechanism provides a clear transmission channel from greater housing wealth to greater self-employment. The implications for startups with paid employees and young-firm employment shares are less clear. "Wanting to be my own boss" is a motive for self-employment but does not require a business with paid employees. However, owning a business with paid employees indulges a taste for bossing others. So, depending on their precise nature, non-pecuniary benefits of owning a business may or may not translate into a wealth effect on the formation of new businesses with paid employees or on young-firm employment shares.

\section{$\underline{\text { Liquidity and Collateral Effects }}$}

Evans and Jovanovic (1989) focus on differences in entrepreneurial ability and liquidity constraints as the key factors determining which individuals start a business. A large follow-on literature concludes that relaxing credit constraints at the household level leads to greater selfemployment and more business startups. Examples include most of the studies cited above on the impact of changes in home equity values on the propensity to become self-employed or start a business. The common theme in these studies is that households can tap home equity gains to relax liquidity constraints, increasing their ability to finance new and young businesses. 
Moreover, banks that make loans to these households (or their businesses) collateralized by home equity become more willing to extend credit as house price gains yield greater home values. Of course, home equity collateral can facilitate the expansion of mature firms as well. As in our discussion of wealth effects, there are good reasons to anticipate proportionally greater effects of local house price gains on local young-firm activity relative to mature-firm activity. Credit Supply Shifts

New and young firms often rely on the owner's personal wealth to finance business activities, but their very newness implies little accumulation of business equity. And few young firms are well positioned to raise equity or debt capital from external investors. For these reasons, new and young businesses are likely to be especially sensitive to credit supply shifts that involve bank loans to businesses and business owners (perhaps secured by housing collateral), personal credit cards, and other sources of credit that young-firm owners and young firms, especially, tap to finance their business activities.

It is helpful to distinguish among various reasons for local credit supply shifts. First, local economic fortunes affect the lending capacity of local banks. Insofar as new and younger firms are relatively dependent on credit from local banks, shocks to the lending capacity of local banks have a greater effect on young firms. The same point holds for local housing developments that affect the lending capacity of local banks. When local banks suffer losses due to a bust in the local housing market, their lending capacities diminish and the credit supply effects are likely to weigh more heavily on younger firms. In other words, the effect of house price movements on young-firm activity shares works partly through the capacity of local lenders to extend credit to young firms and their owners. Other things equal, this impact of local housing market developments on local young-firm activity shares - working through the credit supply channel is smaller when local banks are less important as a source of credit to the local economy.

Second, both local and national banks are likely to see local housing prices as indicators of (future) local business conditions, affecting their willingness to lend. To be sure, this link between house prices and bank lending reflects a perceived shift in business fundamentals rather than a locally exogenous shift in credit supply. Nevertheless, the impact of such a shift in bank willingness to lend to local businesses or their owners falls more heavily on young firms for reasons we have discussed.

Empirically, local house price changes covary positively with changes in the volume of bank loans to local small (and presumably younger) businesses, as shown in Figure 7. To 
construct the figure, we first regress annual log changes in real housing prices and the real volume of bank loans to small businesses at the MSA-year level on state and year fixed effects and annual changes in the state-level unemployment rate. We then construct a bin scatter of the loan volume change residuals against the house price change residuals. Even after sweeping out state, MSA and local cycle effects, there is a strong relationship between house prices and bank loan volume to small businesses. The empirical elasticity of local small business loan volume growth with respect to local house price growth is 0.23 with a t-statistic of about 6 .

Third, local credit supply can shift due to factors that are exogenous to local economic conditions and to local businesses. For example, when a national bank pulls back from lending to smaller and younger firms in a given MSA for reasons other than local economic conditions, it produces a locally exogenous drop in loan supply to young firms in the MSA. Our empirical investigation in Section IV exploits this type of exogenous variation in bank loan supply to estimate the causal effects of local credit supply shifts on local young-firm activity shares.

\section{Consumption Demand Channel}

Recall from Section III that changes in young-firm activity shares covary strongly with business cycle conditions in national and state-level data. These patterns suggest that demands for the goods and services supplied by young firms are more income elastic than the demands for mature-firm products. If so, then local young-firm demands are also likely to be more elastic with respect to wealth shifts induced by local housing market ups and downs. In principle, this type of non-uniform consumption demand shift could fully explain the response of young-firm activity shares to local house price movements that we find in Section IV. We turn next to a novel test of the proposition that local house price changes affect the local economy - including local young-firm activity shares - only through consumption demand channels.

\section{b. Local Industry Responses to Local House Price Changes: A Test}

We now investigate whether and how the local industry growth response to local house price changes depends on the local industry's firm-age structure of employment. If house prices work entirely through consumption demand channels, the local industry response will not depend on its firm-age structure. This invariance proposition is our null hypothesis in the test below. In contrast, if the wealth, liquidity, collateral and credit supply effects described above are at work, the local industry response to local house price changes will rise with the local industry's youngfirm activity share. This proposition is our alternative hypothesis in the test below. 
We implement this test using annual BDS data on employment and the firm-age structure of employment at the industry-by-MSA level from 1992 to 2018. We use the following 14 industry groups for each MSA: Construction (NAICS 23), Manufacturing (31-33), Wholesale Trade (42), Retail Trade (44-45), Transportation and Warehousing (48-49), Information (51), Finance and Insurance (52), Real Estate and Rental and Leasing (53), Professional, Scientific and Technical Services (54), Management of Companies and Enterprises (55), Administrative and Support and Waste Management and Remediation Services (56), Health Care and Social Assistance (62), Arts, Entertainment and Recreation (71) and Accommodation and Food Services (72). We omit Agricultural Services (11), Mining (21) and Utilities (22), because they have positive employment in few MSAs. We omit Educational Services (61) and Other Services (81) because they are dominated by non-profit businesses and religious organizations.

Now consider the regression specification,

$$
\begin{aligned}
G R_{j m t}= & a+b_{1} C Y C_{m t}+b_{2} H P_{m t}+b_{3} Y_{\text {oungSh }} \text { jm,t-1 } \\
& +c \cdot H P_{m t} \times Y \text { oungSh } h_{j m, t-1}+f_{t}+f_{m}+f_{j}+\varepsilon_{j m t}
\end{aligned}
$$

where $G R_{j m t}$ is the log employment change from year $t-1$ to $t$ for industry $j$ in MSA $m, C Y C_{m t}$ is a control for local economic conditions in MSA $m$ in year $t, H P_{m t}$ is the log house price change from year $t-1$ to $t$ in MSA $m$, and YoungSh Im,t-1 $_{\text {is }}$ is the lagged young-firm employment share in industry $j$ and MSA $m$ calculated as the average over the prior five years. The $f$ terms denote fixed effects, and $\varepsilon_{j m t}$ is an error term. As before, we use the change in the local unemployment rate from year $t-1$ to $t$ as our $C Y C_{m t}$ control. The chief coefficient of interest is $c$, which tells us how the local industry-level response to local house price changes depends on the (lagged) young-firm share of employment in the local industry. Formally, the null hypothesis is $c=0$, and the alternative is $c>0$.

Table 6 reports results for (7) fit by OLS and IV. The data resoundingly reject the ageinvariance proposition: $\hat{c}=0.95$ in Column (4) using the IV approach, and a one-sided test of the null hypothesis yields a $t$-statistic of 10. In words, the local industry response to higher local house prices rises with the local industry's young-firm employment share. This result supports the view that local house prices affect the local economy at least partly through wealth, liquidity, collateral and credit supply effects on the propensity to start a new business or expand a young one. Put differently, consumption demand effects do not fully explain the impact of local house prices on local employment. 
The regression controls in column (1) guard against a spurious rejection of the ageinvariance proposition due to certain unmeasured factors. For example, easier credit conditions at the national level may drive a more rapid appreciation of home prices and a credit-fueled increase in young-firm employment shares at the same time. Conversely, tighter credit conditions may slow or reverse home price appreciation and constrict young-firm employment shares. The year effects control for this source of covariation between local house price changes and youngfirm activity shares. Similarly, the inclusion of MSA effects control for the tendency of cities with higher population growth to experience greater home price appreciation and stronger gains in young-firm employment shares.

Column (2) in Table 6 includes a full set of MSA-year effects as controls, with little effect on the coefficient of interest. This result tells us that unmeasured sources of city-level growth rate fluctuations (which might cause systematic co-movements between local changes in home prices and young-firm shares) cannot account for our rejection of the age-invariance proposition. Column (3) adds industry-year effects, and again we reject the age-invariance proposition. Finally, column (4) uses our IV strategy and, once again, the data resoundingly reject the null in favor of the alternative. In short, the statistical evidence against the ageinvariance proposition is overwhelming and unlikely to be caused by omitted factors.

How large are the departures from age invariance? To address this question, we compute the regression-implied response differential between the $90^{\text {th }}$ and $10^{\text {th }}$ percentiles of the youngfirm employment shares across MSA-industry cells. We evaluate this response differential at various points in the distribution of local house price changes. To be precise, we calculate

$$
\text { Response_Diff }=\hat{c}\left(Y_{\text {oungSh }}^{90-10}\right) H P(p) \text {, }
$$

where $\hat{c}$ is the estimated coefficient on the interaction term in regression (7), YoungSh ${ }^{90-10}$ is the 90-10 differential in young-firm employment shares across local industries, and $H P(p)$ is the $p^{\text {th }}$ percentile of annual log changes in MSA-level home prices.

Table 7 quantifies the departures from age invariance. Panels $\mathrm{A}$ and $\mathrm{B}$ report inputs to (8), and panel $\mathrm{C}$ implements the calculation using $\hat{c}=0.95$ from Column (4) in Table 6. Evaluating at the $90^{\text {th }}$ percentile of the MSA-level house price change in the Boom, the employment growth response differential is $3.1 \mathrm{log}$ points per year between local industries at the $90^{\text {th }}$ and $10^{\text {th }}$ percentiles of the young-firm employment share distribution. The cumulative response differential is $12.8 \mathrm{log}$ points over the Boom Period as a whole from 2002 to 2006. 
Evaluating at the $10^{\text {th }}$ percentile of the MSA-level house price distribution in the Bust, the response differential is $-3.8 \mathrm{log}$ points per year. These are large departures from age invariance. Of course, when MSA-level house price changes are small, the induced response differential between industries with high and low young-firm employment shares is small as well.

To assess the robustness of our results in Tables 6 and 7, we undertook two additional investigations. First, one might think that firm-age structure matters for the local industry response to local house price changes only in the construction sector. That turns out not to be the case. When we re-estimate (7) after dropping data for construction, the estimated coefficient on the interaction term remains large, positive, and highly statistically significant. The implied departures from age invariance also remain large. See Appendix Tables B4 and B5. Second, we also estimated a dynamic extension to (7) that lets the chief effect of interest unfold over time, possibly attenuating or amplifying the contemporaneous impact captured by the coefficient, $c$, in (7). As discussed in Appendix D.3 and reported in Table B6, our dynamic extension yields localindustry employment responses to local house price changes that are nearly twice as sensitive to firm-age structure as for the results in Tables 6 and 7.

\section{Assessing Effects on Aggregate Young-Firm Activity Shares}

We now quantify the contribution of house price movements and exogenous loan supply shifts to aggregate fluctuations in young-firm activity shares. We first apply our estimation results to obtain implied paths for changes in local young-firm employment shares. Then we aggregate to the national level using local-area employment shares.

When we quantify the effects of house price changes on local young-firm activity shares, we multiply the IV estimate for $\beta$ by the actual changes in local housing prices. This approach captures the full effect of housing prices on local young-firm activity shares, including their role as a transmission channel through which other shocks drive housing price changes. We think this full effect is the most interesting quantity. Isolating the role of local house price changes as an exogenous driver of young-firm activity shares would require additional assumptions to disentangle the exogenous and endogenous components of house price movements. ${ }^{15}$

\footnotetext{
15 The first stage in the IV estimation identifies exogenous house price movements, but there's no reason to think it captures all, or even most, of the movements in housing prices that are exogenous with respect to local young-firm employment shares.
} 
There are three other important points to keep in mind about our aggregate quantification exercise. First, and most obviously, the exercise proceeds under an assumption of correctly identified casual effects at the local level.

Second, local causal effects need not aggregate as simply as we presume. For example, a drop in young-firm activity in one area could raise young-firm activity in other areas through a spatial substitution response in product and factor markets. Conversely, young-firm activity in one area could have positive spillover effects on young-firm activity in other areas. As a separate point that cuts in the same direction, entrepreneurs can own houses outside the area where they operate young firms. This fact raises the possibility that local house price changes in one area directly affect young-firm activity shares in other areas, a possibility neglected by our statistical models. The net effect of these spatial forces is unclear to us, even as to direction, but we see no reason to think they are large relative to the effects captured by our models. Still, we recognize that our neglect of spatial spillover and spatial equilibrium considerations may bias our assessment of aggregate implications.

Third, recall that our econometric specifications include period fixed effects as controls. These controls condition out the common response across local areas to economy-wide developments. For example, if a national housing bust leads to a broad constriction in credit supply - and that constriction has disproportionately large effects on the employment growth of new and young firms - then the housing bust lowers the national young-firm employment share in a manner not reflected in our aggregate quantification exercise. The same point holds in reverse for a national housing boom. The upshot is that our quantification exercise may understate the full effect of the national housing boom and bust on fluctuations in young-firm employment shares, because it neglects the general equilibrium effects of national housing booms and busts that affect credit availability in a similar way across local areas.

Figure 8 implements our quantification exercise using the IV estimates for $\beta$ in column (5) of Table 1. The solid bars reproduce Figure 2. The striped bars show the model-implied paths for aggregate changes in young-firm employment shares on a year-by-year basis. We treat states as local areas for this purpose, so we can push the quantification exercise back to the early 1980s. State-level data also let us cover the entire United States, including rural areas. ${ }^{16}$ As in Figure 2,

\footnotetext{
${ }^{16}$ Re-estimating our statistical model on state-level instead of MSA-level data yields estimates
} for $\beta$ similar to the ones reported in Table 1, but the point estimates are less precise. 
we express both actual and model-implied paths as deviations from the sample trend. ${ }^{17}$

The results in Figure 8 show that housing market ups and downs are a major force behind cyclical and medium-run fluctuations in young-firm activity shares. About 75 percent of the sharp decline in the young-firm employment share during the Great Recession (from 2008 to 2010) reflects the effects of housing price declines. Housing price movements also play an important role in several other cycle episodes. The cumulative effect of housing price gains from 1998 to 2006 raised the national young-firm employment share by $12 \log$ points. That stimulus to young-firm activity offset more than one-half of the trend decline in young-firm employment during this period. However, this boost to the young-firm employment share during the national housing boom was completely undone from 2008 to 2013 as a result of the national housing bust.

Figure 9 repeats the quantification exercise using our extended statistical model with bank loan supply shocks. The role of housing price movements implied by the extended model is very similar to before. However, the extended model also implies a distinct role for small business bank loan supply shocks as drivers of fluctuations in young-firm shares. Figure 9 shows that a contraction in small business lending during the Great Recession further depressed the aggregate young-firm employment share. The joint contribution of the housing bust and the pullback in small business bank lending accounts for 120 percent of the huge drop in the youngfirm employment share (relative to trend) during the 2008-2010 period. 105 percent of the 120 percent is due to housing prices and the remainder due to small business lending shocks.

Shocks to the supply of small business lending also have material effects on the youngfirm share in a few other cycle episodes. During the 2001-03 period, housing price changes and small business lending shocks worked to offset other forces that reduced the young-firm employment share. These other forces probably include the fallout from the dotcom bust and the recession in the early 2000s. During the recovery after the Great Recession period in 2012 and 2013, housing prices and small business lending worked in opposite directions. Housing price developments continued to act as a drag on young-firm employment shares, while small business lending provided a modest boost. Later, from 2016 to 2018, both housing prices and small business bank lending provided a boost to young-firm employment shares relative to trend.

\footnotetext{
17 The growth in our national housing price index is nearly identical to the employment-weighted growth of our state-level housing price indices. Thus, given the linearity of our statistical model, multiplying the log change in the national housing price index by the estimated value for $\beta$ yields nearly identical results to the ones displayed in Figure 8.
} 
Overall, this figure shows that our extended statistical model explains a good deal of the aggregate fluctuations in young-firm shares since the late 1990s. But there are also notable fluctuations in young-firm shares not explained by our model. In particular, the large declines in 2001 and 2003 are not explained by our model. However, our model does imply that house price gains and (to a small extent) loan supply shifts dampened the magnitude of those declines.

\section{Concluding Remarks}

The share of American workers at young firms displays a clear pattern of procyclical movements about a declining trend in recent decades. Cyclical drops in the young-firm employment share were especially large in the contractions of the early 1990s and the Great Recession. At the local level, changes in young-firm employment shares covary in a strongly positive manner with local cycle conditions and local housing price growth.

These patterns motivate our efforts to estimate the causal effects of housing market developments on young-firm employment shares. Deploying an IV strategy, we find large positive effects of local house price changes on changes in local young-firm activity shares. We also identify a distinct and smaller role for locally exogenous shifts in bank loan supply. Aggregating local effects to the national level, housing market ups and downs play a major role as transmission channel and driving force - in medium-run fluctuations in young-firm employment shares in recent decades.

The housing boom from 1998 to 2006 drove a cumulative 12 log-point gain in the national young-firm employment share, according to our quantification analysis, offsetting more than half the ongoing trend decline in the young-firm share during this period. The ensuing bust in housing prices completely reversed the preceding positive effects on young-firm employment shares. Thus, three sets of forces came together after the mid-2000s to bring about a substantial drop in the employment share of young firms. First, the collapse in housing prices from 2007 reduced the young-firm share through wealth, liquidity, collateral, credit supply and consumption demand channels. Second, secular forces continued to reduce the young-firm share. ${ }^{18}$ Third, a contraction in bank loan supply further reinforced the drop in young-firm employment shares during the Great Recession.

${ }^{18}$ Inquiries into the secular forces in play include Davis and Haltiwanger (2014), Decker et al. (2014b), Karahan et al. (2015), Molloy et al. (2016) and Pugsley and Şahin (2019). 
We also implement a novel test that throws light on how housing prices affect the local economy. The test turns on the following observation: if house price effects work entirely through consumption demand channels, then local industry growth responses to house price changes do not vary with the firm-age structure of employment. We find overwhelming evidence against this age-invariance hypothesis. The direction of departures supports the view that house prices affect local economies at least partly through wealth, liquidity, collateral and credit supply effects on the propensity to start a new business or expand a young one. We also show that the firm-age structure of employment underpins large, persistent spatial differentials in local industry growth rate responses to local house price changes. That is, the local industry growth rate response to local house price changes is larger when young firms account for a larger share of local industry employment.

Our results also support the empirical relevance of theoretical propagation mechanisms that rest on firm entry dynamics and young-firm activity levels. Clementi and Palazzo (2016), for example, show how firm entry and exit behavior amplifies the effects of common shocks and propagates their effects forward in time. ${ }^{19}$ Seen in this light, our results suggest that the housing market bust and the credit supply contraction during the 2007-2010 period slowed the recovery from the recession through their negative effects on business formation and young firms.

${ }^{19}$ Recent related work includes Gourio et al. (2016), Moreira (2017) and Luttmer (2019). Clementi and Palazzo (2016) provide references to earlier work on the role of firm entry and exit in shock amplification and propagation. 


\section{References}

Adelino, Manuel, Antoinette Schoar and Felipe Severino, 2015. "House Prices, Collateral, and Self-Employment," Journal of Financial Economics, 117, no. 2 (August), 288-306.

Agarwal, Sumit, Gene Amromin, Souphala Chomsiseng, Tim Landvoigt, Tomasz Piskorski, Amit Seru and Vincent Yao, 2020. "Mortgage Refinancing, Consumer Spending, and Competition: Evidence from the Home Affordable Refinancing Program," NBER Working Paper No. 21512.

Black, Jane, David de Meza and David Jeffreys, 1996. "House Price, the Supply of Collateral and the Enterprise Economy," Economic Journal, 106, 60-75.

Burcu, Duygang-Bump, Alexey Levkov and Judit Montoriol-Garriga, 2015. "Financing Constraints and Unemployment: Evidence from the Great Recession," Journal of Monetary Economics, 75 (October), 89-105.

Chodorow-Reich, Gabriel, 2014. "The Employment Effects of Credit Market Disruptions: FirmLevel Evidence from the 2008-09 Financial Crisis," Quarterly Journal of Economics, 129, no. $1,1-59$.

Clementi, Gian Luca and Beradino Palazzo, 2016. "Entry, Exit, Firm Dynamics, and Aggregate Fluctuations," American Economic Journal: Macroeconomics, 8, no. 3, 1-41.

Davidoff, Thomas, 2016. "Supply Constraints Are Not Valid Instrumental Variables for Home Prices Because They Are Correlated with many Demand Factors," Critical Finance Review, 5, 177-206.

Davis, Steven J., Jason Faberman and John Haltiwanger, 2012. "Labor Market Flows in the Cross Section and over Time," Journal of Monetary Economics, January.

Davis, Steven J., R. Jason Faberman, John Haltiwanger, Ron Jarmin, and Javier Miranda, 2010. "Business Volatility, Job Destruction, and Unemployment." American Economic Journal: Macroeconomics, 2, no. 1 (April), 259-287.

Davis, Steven J. and John Haltiwanger, 1992. "Gross Job Creation, Gross Job Destruction, and Employment Reallocation," Quarterly Journal of Economics, 107, no 3., 819-863.

Davis, Steven J. and John Haltiwanger, 1999. "Gross Job Flows," in Handbook of Labor Economics, Volume 3, edited by Orley Ashenfelter and David Card. Elsevier Science.

Davis, Steven J. and John Haltiwanger, 2014. "Labor Market Fluidity and Economic Performance," in Re-Evaluating Labor Market Dynamics, Federal Reserve Bank of Kansas City. Also available at NBER Working Paper No. 20479.

Davis, Steven J. and John Haltiwanger, 2019. "Dynamism Diminished: The Role of Housing Markets and Credit Conditions," BFI Working Paper 2019-05.

Davis, Steven, John Haltiwanger, Ron Jarmin, C.J. Krizan, Javier Miranda, Al Nucci, and Kristin Sandusky, 2009. "Measuring the Dynamics of Young and Small Businesses: Integrating the Employer and Non-Employer Businesses," in Producer Dynamics: New Evidence from Micro Data, (Dunne, Jensen and Roberts, eds.) NBER/University of Chicago Press, 329-366.

Davis, Steven J., John Haltiwanger, Ron Jarmin, and Javier Miranda, 2007. "Volatility and Dispersion in Business Growth Rates: Publicly Traded versus Privately Held Firms." NBER Macroeconomics Annual, 2006.

Davis, Steven J., John Haltiwanger and Scott Schuh, 1994. "Small Business and Job Creation: Dissecting the Myth and Reassessing the Facts," in Labor Economics, Employment Policy, and Job Creation, edited by Lewis C. Solmon and Alec R. Levenson. Westview Press.

Davis, Steven J., John Haltiwanger and Scott Schuh, 1996. Job Creation and Destruction, Cambridge, Massachusetts: MIT Press. 
Decker, Ryan, John Haltiwanger, Ron S. Jarmin and Javier Miranda, 2014a. "The Role of Entrepreneurship in US Job Creation and Economic Dynamism," Journal of Economic Perspectives, 28 no. 3 (Summer), 3-24.

Decker, Ryan, John Haltiwanger, Ron S. Jarmin and Javier Miranda, 2014b. "The Secular Decline of Business Dynamism in the United States," working paper, University of Maryland.

Evans, David S. and Boyan Jovanovic, 1989. "An Estimated Model of Entrepreneurial Choice under Liquidity Constraints," Journal of Political Economy, 97, no. 4, 808-827.

Fairlie, Robert W. and Harry A. Krashinsky, 2012. "Liquidity Constraints, Household Wealth, and Entrepreneurship Revisited," Review of Income and Wealth, 58, no. 2 (June).

Fan, Fei and Michelle J. White, 2003. "Personal Bankruptcy and the Level of Entrepreneurial Activity," Journal of Law and Economics, 46, 2 (October), 545-567.

Fort, Teresa C., John Haltiwanger, Ron S. Jarmin and Javier Miranda, 2013. "How Firms Respond to Business Cycles: The Role of Firm Age and Firm Size," IMF Economic Review, 520-559.

Fujita, Shigeru, 2012. "Labor Market Anxiety and the Downward Trend in the Separation Rate," Business Review, Federal Reserve Bank of Philadelphia.

Gentry, William M. and R. Glenn Hubbard, 2004. "Entrepreneurship and Household Saving," B.E. Journal of Economic Analysis and Policy, 4, no. 1 (August),

Gertler, Mark and Simon Gilchrist, 1994. "Monetary Policy, Business Cycles, and the Behavior of Small Manufacturing Firms," Quarterly Journal of Economics, 109, no. 2 (May), 309-340.

Gourio, Francois, Todd Messer and Michael Siemer, 2016. "Firm Entry and Macroeconomic Dynamics: A State-Level Analysis," American Economic Review, 196, no. 5 (May), 214-18.

Greenstone, Michael, Alexandre Mas and Hoai-Luu Nguyen, 2020. "Do Credit Market Shocks Affect the Real Economy? Quasi-Experimental Evidence from the Great Recession and 'Normal' Economic Times," American Economic Journal: Economic Policy, 12, no. 1, 200 225.

Guiso, Luigi and Monica Paiella, 2008. "Risk Aversion, Wealth, and Background Risk." Journal of the European Economic Association, 6, no. 6 (December), 1109-1150.

Guren, Adam M., Alisdair McKay, Emi Nakamura and Jon Steinsson, 2021. "Housing Wealth Effects: The Long View." The Review of Economic Studies, 88, no. 2, 669-707.

Haltiwanger, John, Ian Hathaway, and Javier Miranda, 2014. "Declining Dynamism in the U.S. High-Technology Sector," Ewing Marion Kauffman Foundation (February).

Haltiwanger, John, Ron S. Jarmin and Javier Miranda, 2013. "Who Creates Jobs? Small versus Large versus Young," Review of Economics and Statistics, 95, no. 2 (May), 347-361.

Haltiwanger, John, Ron S. Jarmin, Robert Kulick and Javier Miranda, 2017. "High Growth Young Firms: Contributions to Job, Output and Productivity Growth.” In Measuring Entrepreneurial Businesses, edited by John Haltiwanger, Erik Hurst, Javier Miranda and Antoinette Schoar, Chicago: University of Chicago Press

Haltiwanger, John, Henry Hyatt, Lisa Kahn and Erika McEntarfer, 2018. "Cyclical Job Ladders by Firm Size and Firm Wage," American Economic Journal: Macroeconomics, 10, no. 2, 5285.

Haltiwanger, John, Henry Hyatt, and Erika McEntarfer, 2018. "Who Moves Up the Job Ladder?" Journal of Labor Economics, 36(S1), 301-336.

Harding, John and Stuart S. Rosenthal, 2017. "Homeownership, Housing Capital Gains and SelfEmployment," Journal of Urban Economics, 99, 120-135.

Hathaway, Ian and Robert Litan, 2014. "Declining Business Dynamism in the United States: A Look at States and Metros," Economic Studies at Brookings, May. 
Holtz-Eakin, Douglas, David Joulfaian and Harvey S. Rosen, 1994. "Sticking It Out Entrepreneurial Survival and Liquidity Constraints." Journal of Political Economy, 102, no. 1, 53-75.

Huang, Haifang and Eric Stephens, 2015. "From Housing Bust to Credit Crunch: Evidence from Small Business Loans," Canadian Journal of Economics, 48, no. 3, 853-880.

Hurst, Erik G. and Annamaria Lusardi, 2004. "Liquidity Constraints, Household Wealth and Entrepreneurship." Journal of Political Economy, 112, no. 2, 319-347.

Hurst, Erik G. and Benjamin W. Pugsley, 2017. "Wealth, Tastes and Entrepreneurial Choice," in Measuring Entrepreneurial Businesses: Current Knowledge and Challenges, edited by J. Haltiwanger, E. Hurst, J. Miranda and A. Schoar.

Hurst, Erik G. and Frank Stafford, 2004. "Home Is Where the Equity Is: Mortgage Refinancing and Household Consumption," Journal of Money, Credit and Banking, 36, no. 6 (December), 985-1014.

Hyatt, Henry R. and James R. Spletzer, 2013. "The Recent Decline in Employment Dynamics." IZA Journal of Labor Economics, 2, no. 5 (September).

Jensen, Thais Laerkholm, Soren Leth-Petersen and Raman Nanda, 2021. "Financing Constraints, Home Equity and Selection into Entrepreneurship," Journal of Financial Economics, forthcoming.

Karahan, Fatih, Ben Pugsley and Așegül Şahin, 2015. "Understanding the 30-Year Decline in the Business Startup Rate: A GE Approach,” working paper.

Khilstrom, Richard E. and Jean-Jacques Laffont, 1979. "A General Equilibrium Entrepreneurial Theory of Firm Formation Based on Risk Aversion," Journal of Political Economy, 87, no. 4 (August), 719-748.

Lazear, Edward P. and James R. Spletzer, 2012. "Hiring, Churn and the Business Cycle," American Economic Review Papers \& Proceedings, 102, no. 3 (May), 575-579.

Luttmer, Erzo G.J., 2019. "Slow Convergence in Economies with Organization Capital," working paper, Federal Reserve Bank of Minneapolis.

Lux, Marshall and Robert Greene, 2015. "The State and Fate of Community Banking," Harvard Kennedy School, M-RCBG Associate Working Paper Series, No. 37.

Mehrotra, Neil and Dmitriy Sergeyev, 2021. "Financial Shocks and Job Flows," working paper, 25 October.

Mian, Atif and Amir Sufi, 2009. "The Consequences of Mortgage Credit Expansion: Evidence from the U.S. Mortgage Default Crisis," Quarterly Journal of Economics, 124, 1449-1496.

Mian, Atif and Amir Sufi, 2011. "House Prices, Home Equity-Based Borrowing, and the U.S. Household Leverage Crisis," American Economic Review, 101 (August), 2132-2156.

Mian, Atif and Amir Sufi, 2014. "What Explains the 2007-2009 Drop in Employment?" Econometrica, 82, no. 6 (November), 2197-2333.

Mian, Atif, Amir Sufi and Francesco Trebbi, 2015. "Foreclosures, House Prices and the Real Economy," Journal of Finance, 70, no. 6 (December), 2587-2634.

Molloy, Raven, Christopher Smith, Riccardo Trezi and Abigail Wozniak, 2016. "Understanding Declining Fluidity in the U.S. Labor Market," Brookings Papers on Economic Activity, Spring, 183-259.

Moreira, Sara, 2017. "Firm Dynamics, Persistent Effects of Entry Conditions, and Business Cycles," working paper, Kellogg School of Management, Northwestern University.

Pugsley, Benjamin W. and Ayşegül Şahin, 2019. "Grown-Up Business Cycles," Review of Financial Studies, 32, no. 3 (March), 1102-1147.

Saiz, Albert, 2010. "The Geographic Determinants of Housing Supply Elasticity," Quarterly Journal of Economics, 125, no. 3 (August), 1253-1296. 
Schmalz, Martin C., David A. Sraer, and David Thesmar, 2017. "Housing Collateral and Entrepreneurship," Journal of Finance, 72, no 1, 99-132.

Siemer, Michael, 2019. "Employment Effects of Financial Constraints During the Great Recession," Review of Economics \& Statistics, 101, no. 1, 16-29. 
Figure 1. Share of Employees at Young Firms, U.S. Nonfarm Private Economy, 1981-2018

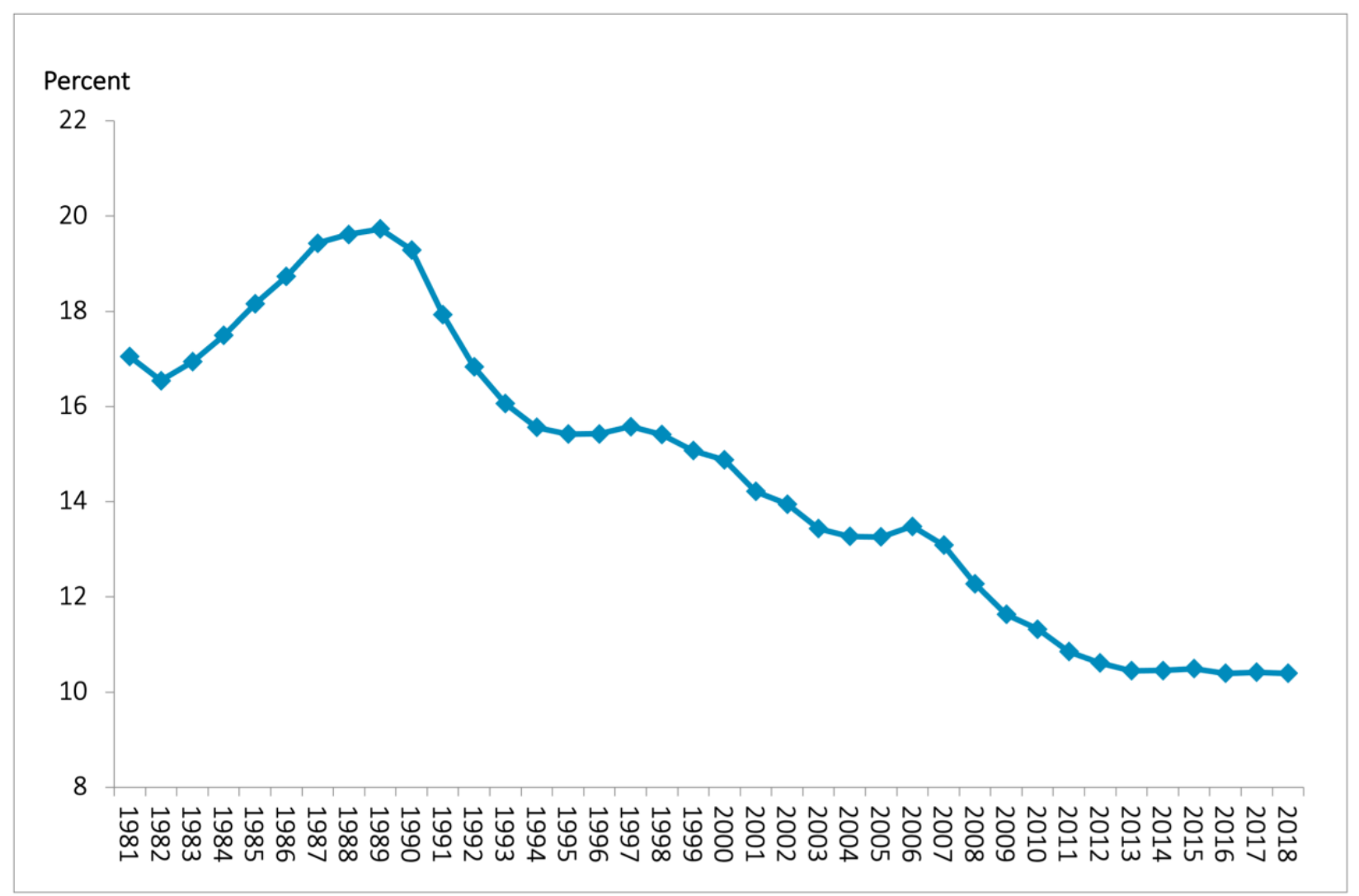

Notes: Data are from Business Dynamic Statistics (BDS) and reflect mid-March payrolls in the indicated calendar year. When it first becomes a legal entity, firm age equals the then-current age of its oldest establishment in years. Thereafter, firm age advances by one with the passage of each year. Establishment age is the number of years since operations began in the same narrowly defined industry. "Young" means fewer than six years (72 months) since hiring the first paid employee. 
Figure 2. Cyclicality of Log Changes in the Young-Firm Share of Private Sector Employees

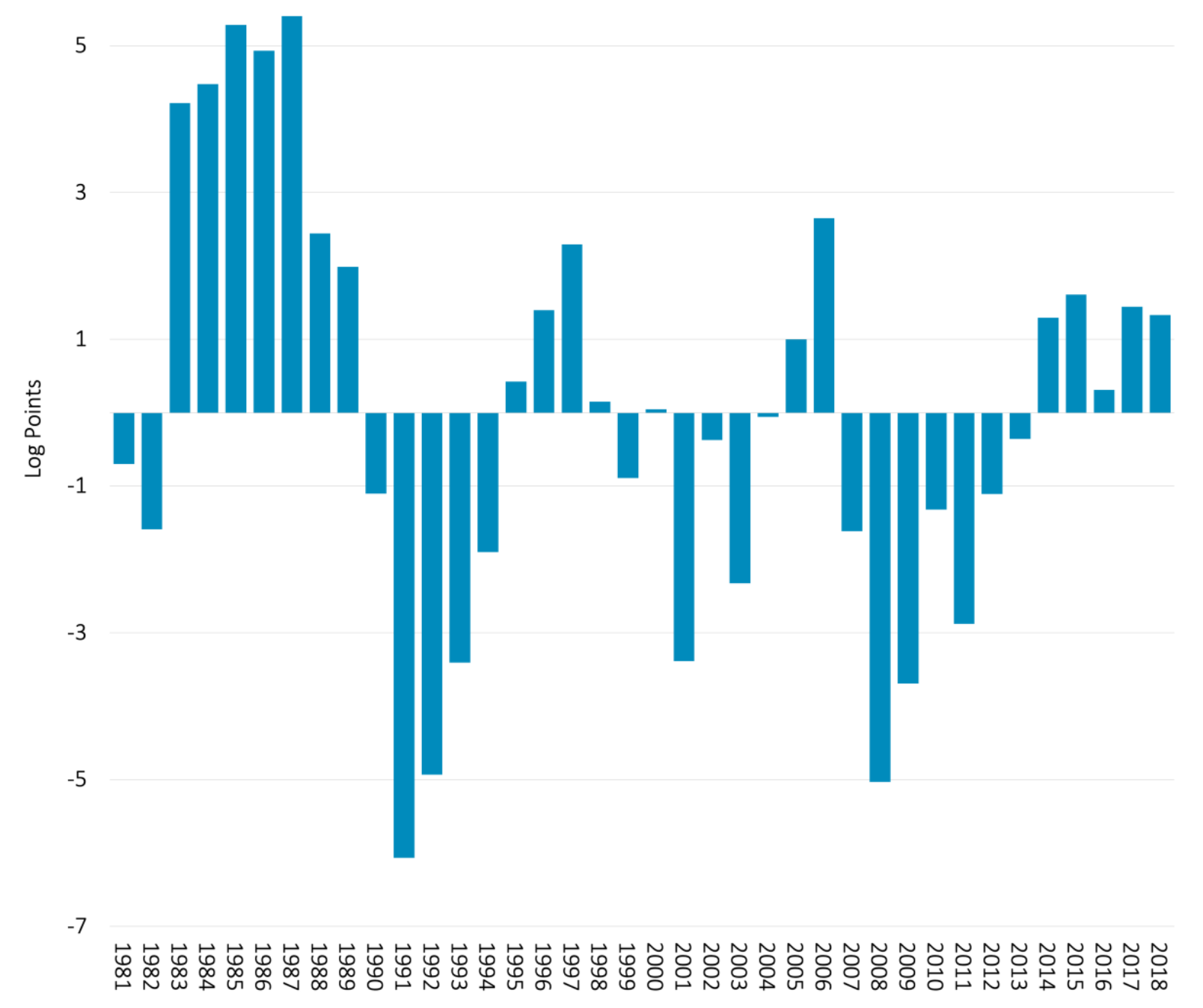

Notes: Each bar shows the annual average log change in the share of private sector employees at young firms during the indicated cycle episode, deviated about the sample mean log change of minus $1.4 \log$ points per year from 1981-2018. Annual log changes are from one mid-March payroll period to the next. See notes to Figure 1 for additional information and Section 2 for an exact description of the calculations. 
Figure 3A: Relationship Between Log Difference in Young-Firm Employment Share and the Change in the Unemployment Rate, State-by-Year Data, 1981-2018 (Bin Scatter)

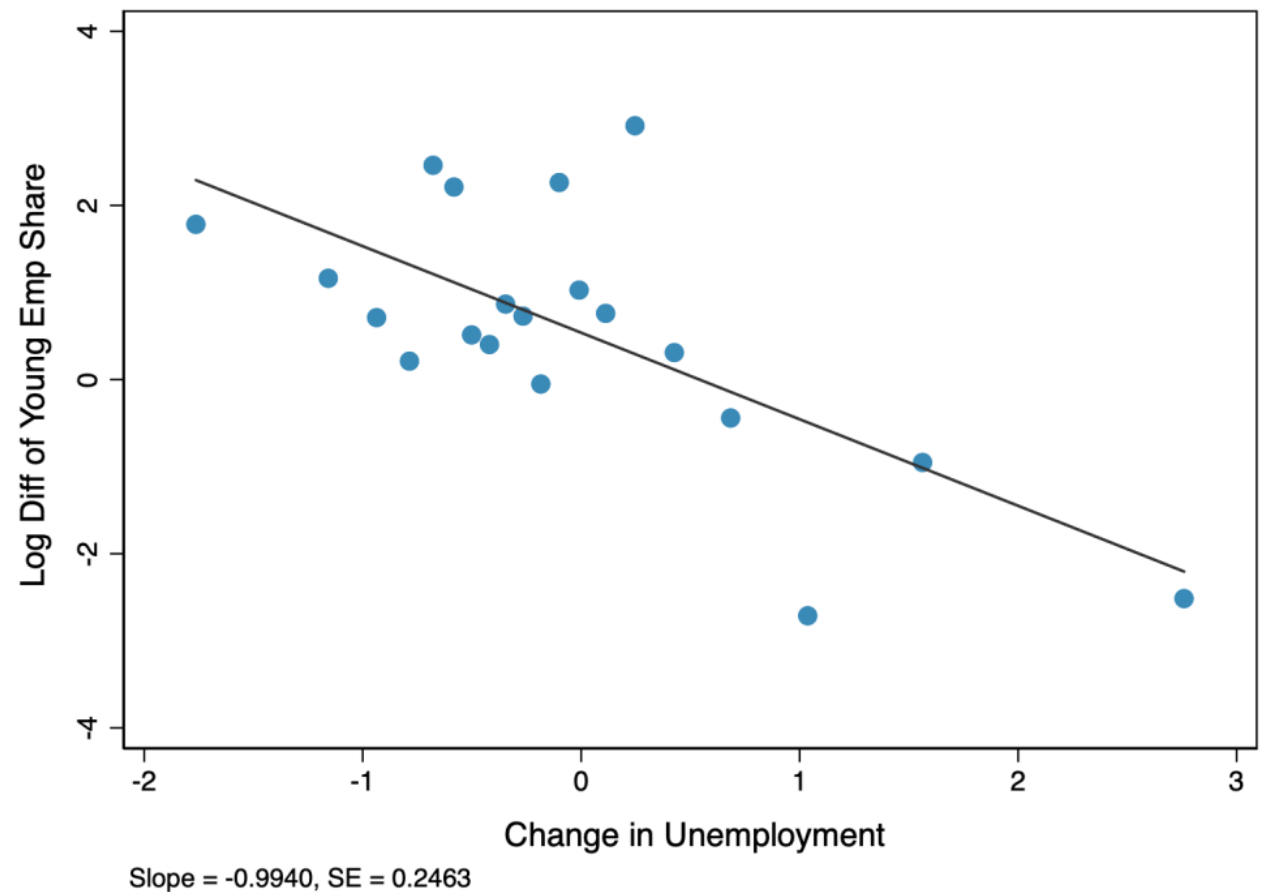

Figure 3B: Relationship Between Log Difference in Young Employment Share and Growth Rate of Real Housing Price, State-by-Year Data, 1981-2018 (Bin Scatter)

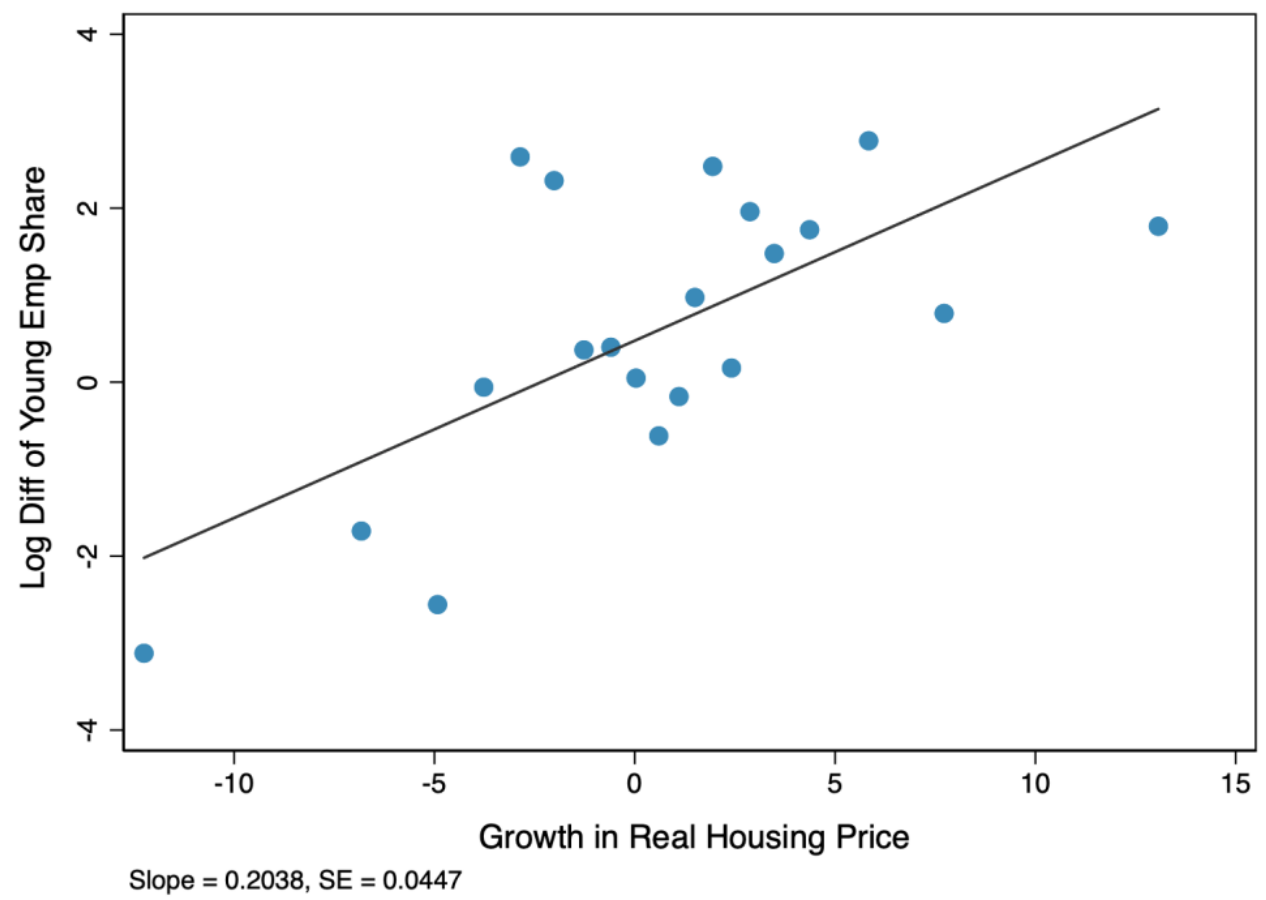

Notes: In Panel A, the scale is in log points on the vertical axis and percentage points on the horizontal axis. In Panel B, the scale is log points on both axes. Appendix Figures B6A and B6B display scatter plots of the raw data. 
Figure 4. Relationship Between Log Difference in Young-Firm Employment Share and Growth Rate of Real Housing Prices, MSA-by-Year Data, 1992 to 2018

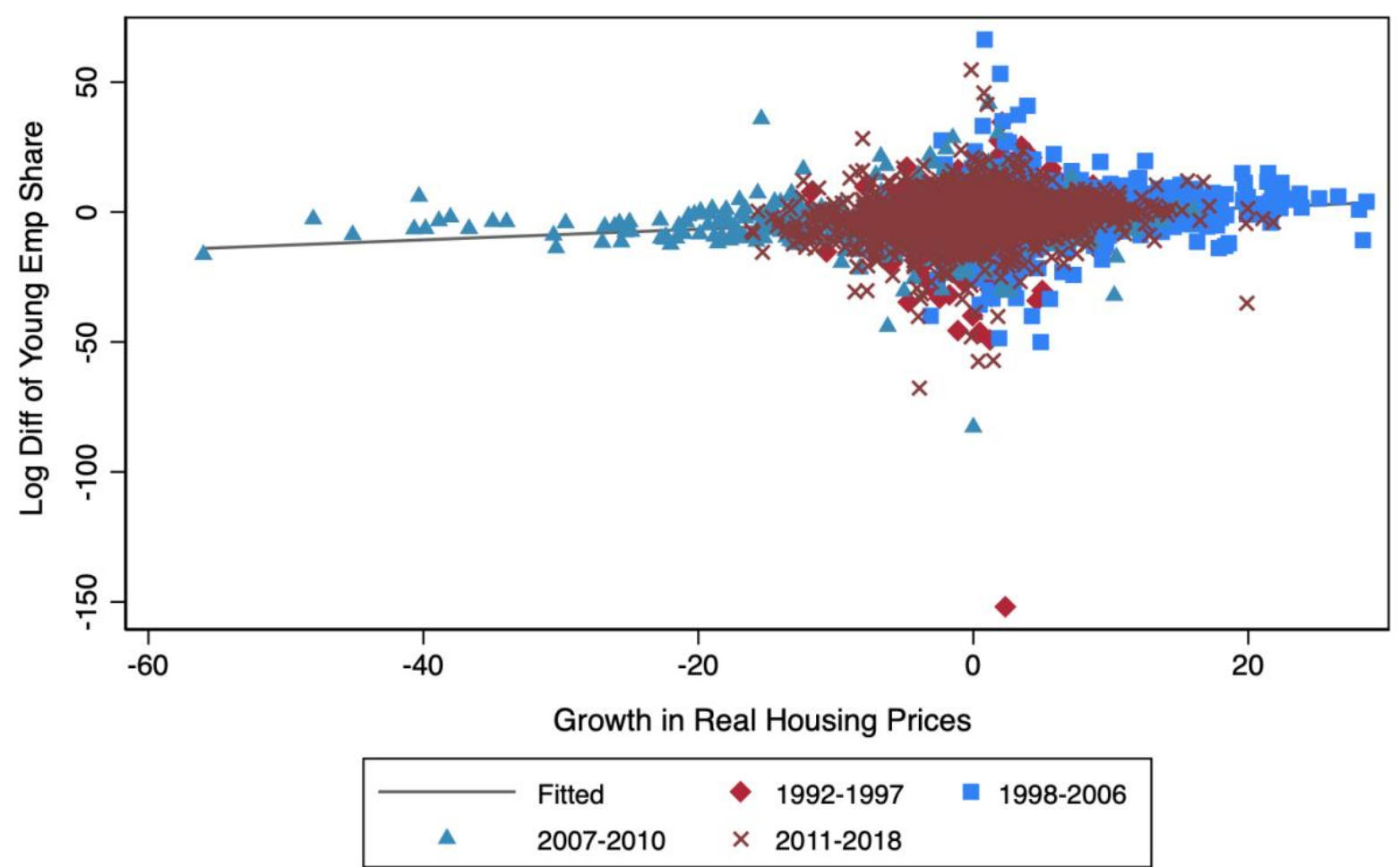

Slope $=0.207, \mathrm{SE}=0.018$

Mean Growth Rate of Housing Prices:

Full Sample $=0.810,1992-1997=0.4901998-2006=3.281,2007-2010=-3.349,2011-2018=0.344$ 
Figure 5. Share of Employment at Small Firms (Fewer than 20 paid employees), 1981-2018, U.S. Nonfarm Private Economy

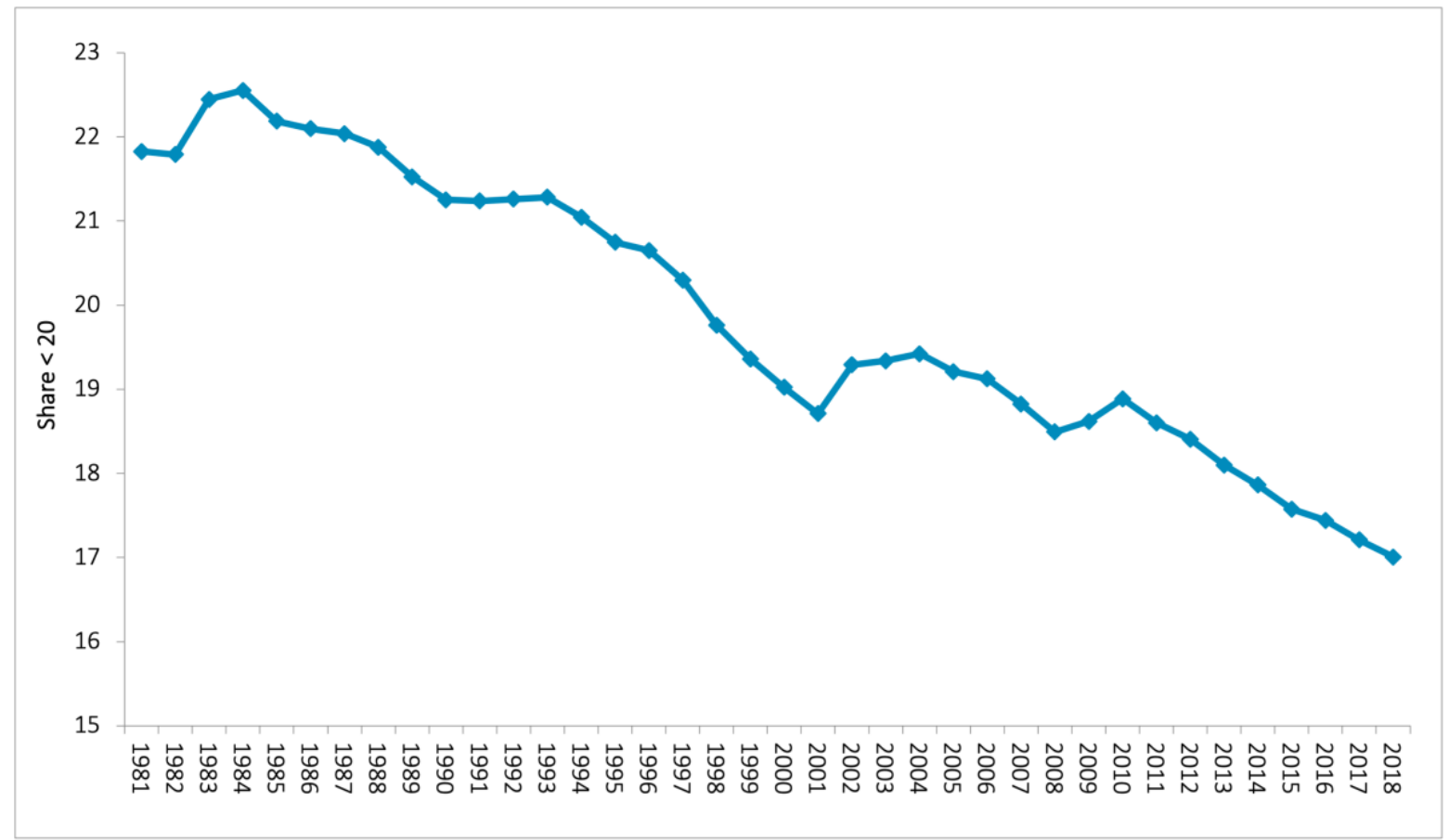


Figure 6. Annual Log Changes in the Employment Share of Small Firms, Deviated about mean Annual Log Change from 1981 to 2018 of -0.6

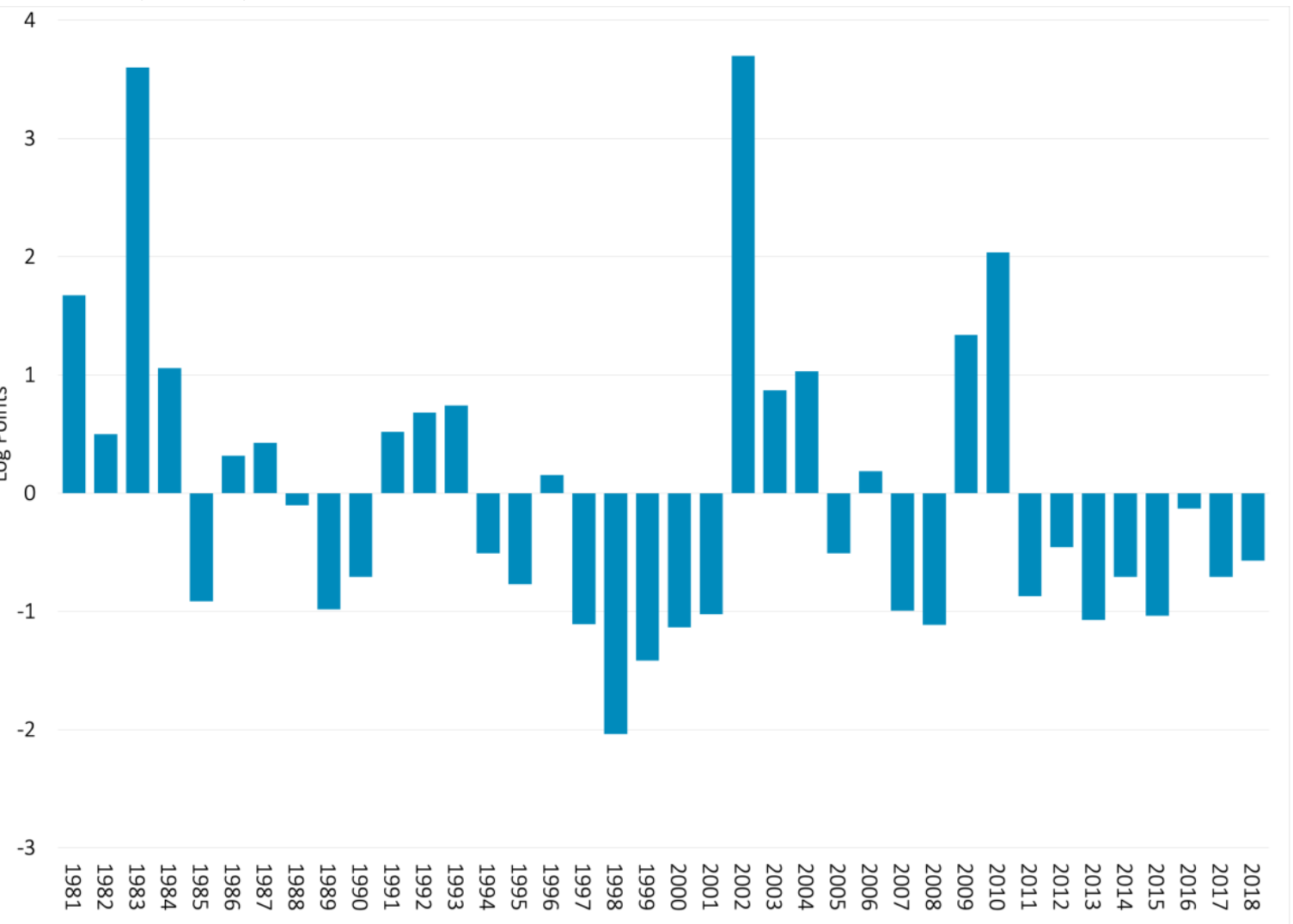

Figure 7. Co-Movements in Housing Price Growth and Small Business Loan Volume Growth in MSA-Year Data, Controlling for MSA and Year Effects and Local Cycle Variation, 1999-2018 (Bin Scatter) 


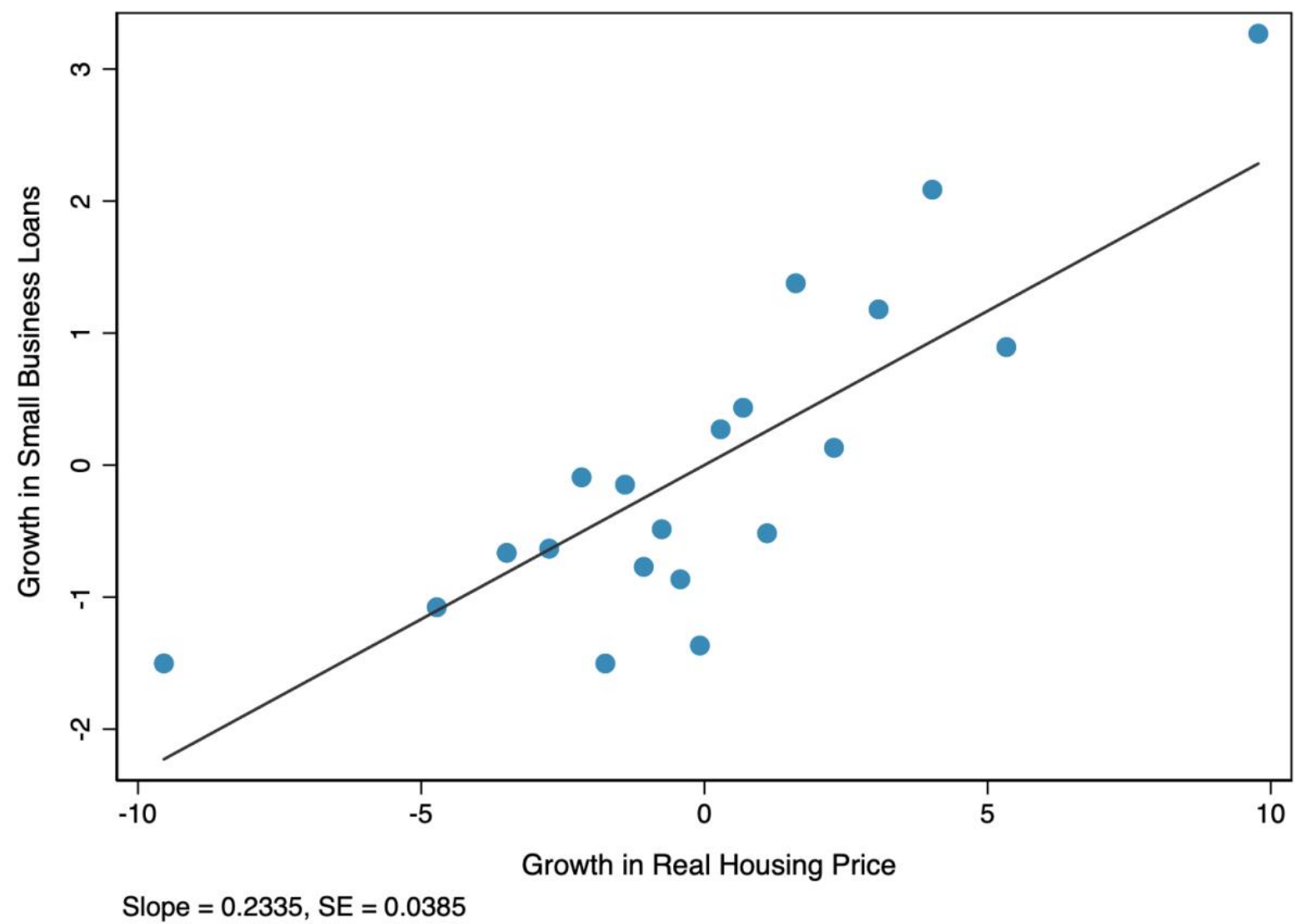

Notes: The scale is in log points on both axes. Appendix Figure B15 displays a scatter plot of the raw data. 
Figure 8. Contributions of Housing Market Ups and Downs to Aggregate Changes in YoungFirm Employment Shares from 1981 to 2018

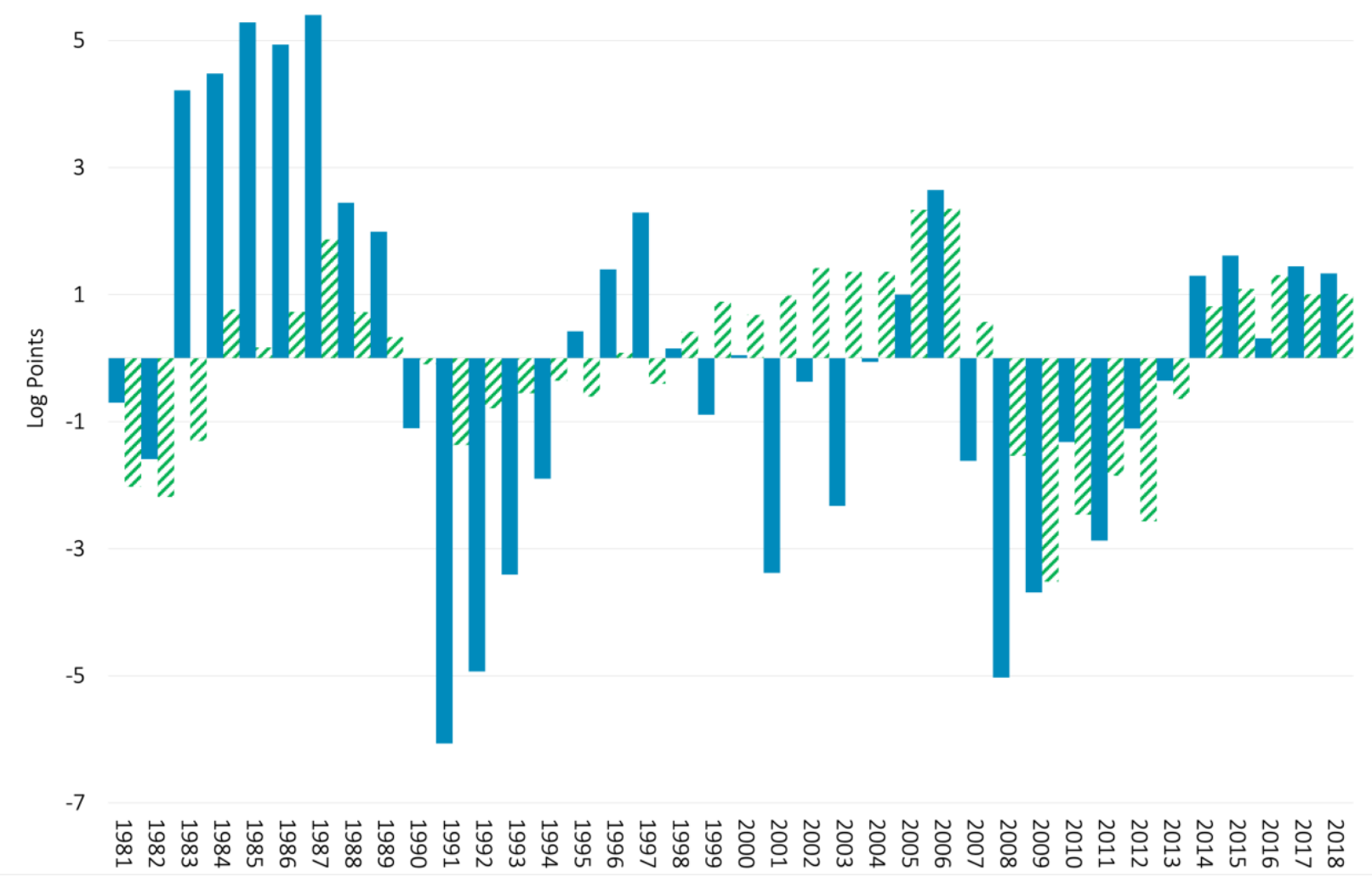

Notes: Solid (blue) bars show annualized log changes in young-firm employment shares, deviated about the sample mean change of minus $1.4 \mathrm{log}$ points per year from 1981-2018. Striped (green) bars show the aggregated model-implied changes using the estimate for $\beta$ in column (5) of Table 1 and actual housing price log changes. 
Figure 9. Contributions of Housing Market Ups and Downs and Bank Loan Supply Shocks to Aggregate Changes in Young-Firm Employment Shares from 1999 to 2018

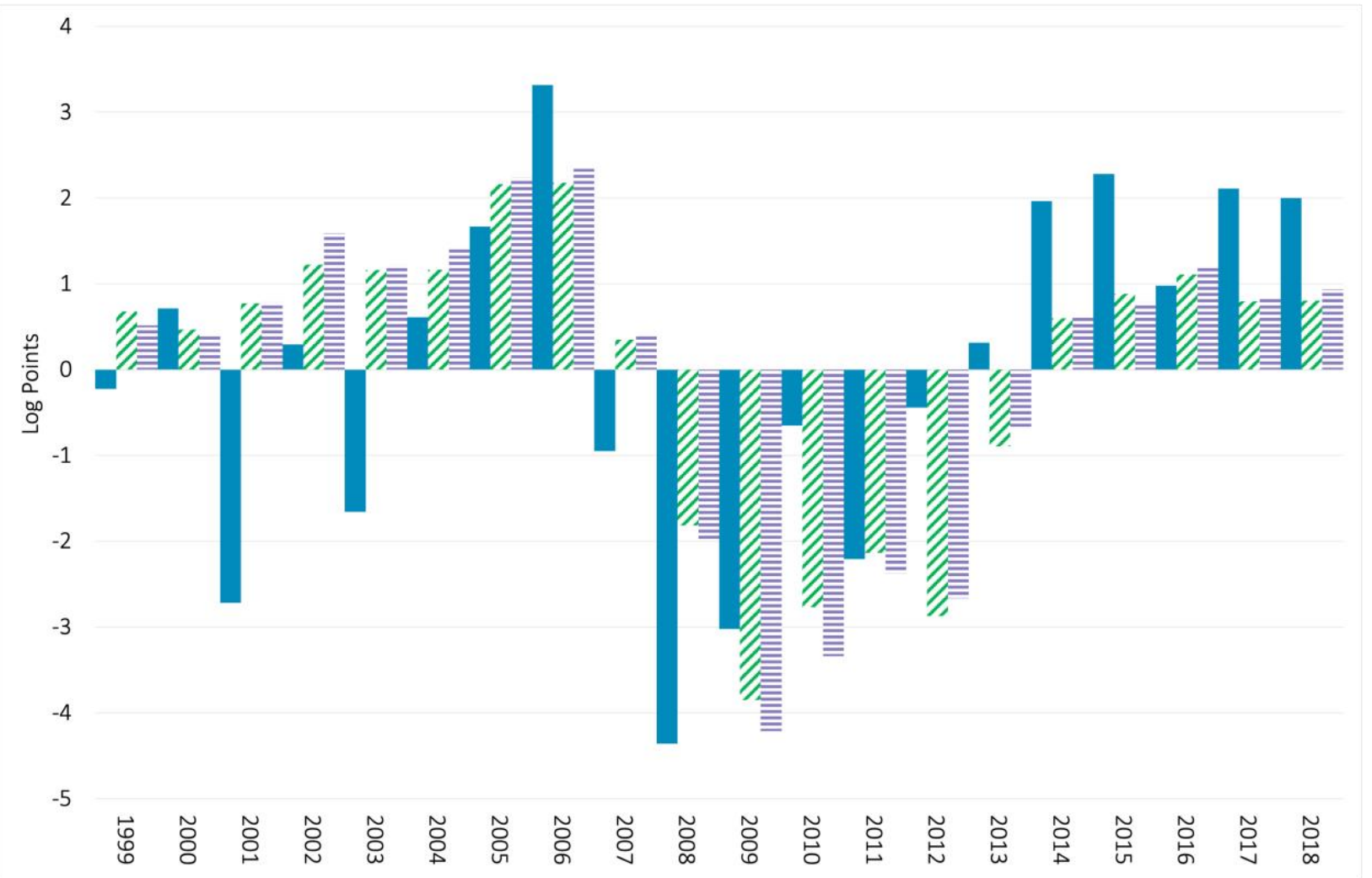

Notes: The solid (blue) bar is the actual log change, the diagonal striped (green) bar is the modelimplied change for housing prices only, and the horizontal striped (purple) bar is the sum of the two. The figure uses coefficient estimates from column (5) in Table 2. All displayed quantities are deviated about the actual sample mean of minus $2.0 \log$ points per year from 1999 to 2018 . 
Table 1. Estimated Effects of Local Housing Price Growth on Young-Firm Employment Shares, Annual MSA-level Data from 1992 to 2018

Dependent Variable: Annual log change in MSA young-firm employment share

\begin{tabular}{lllllll}
\hline & $(1)$ & $(2)$ & $(3)$ & $(4)$ & $(5)$ & $(6)$ \\
\hline & OLS & IV & OLS & IV & IV & IV(S) \\
Coefficient on log real & 0.188 & 0.414 & 0.070 & 0.343 & 0.357 & 0.296 \\
Housing price change $(\beta)$ & $(0.018)$ & $(0.089)$ & $(0.019)$ & $(0.091)$ & $(0.105)$ & $(0.138)$ \\
\hline F-test for Excl. Instruments & & 44.5 & & 45.5 & 41.2 & 39.8 \\
MSA Effects & Yes & Yes & Yes & Yes & Yes & Yes \\
Year Effects & No & No & Yes & Yes & Yes & Yes \\
MSA Bartik Demand Control & No & No & No & No & Yes & Yes \\
MSA Population Growth Rate & No & No & No & No & Yes & Yes \\
\hline
\end{tabular}

Notes: Standard errors in parentheses, with clustering at the MSA level. All specifications include annual changes in the MSA unemployment rate as an additional control. Specifications without year effects include a quadratic in the national GDP growth rate. "IV" specifications instrument for MSA-level house price changes using interactions between a cubic polynomial in the Saiz (2010) housing supply elasticity values and the annual change in the MSA-level unemployment rate. The "IV(S)" specification instead uses a quadratic polynomial in the inverse of estimated price-sensitivity coefficients to construct instruments. See Appendix D.1 for details on how we estimate the price sensitivities, following Guren et al. (2021). For each IV and IV(S) model, overidentification tests fail to reject the null of instrument validity. We use 6,257 observations in estimating each regression model.

Table 2. Young-Firm Employment Share Responses to Local Housing Price Growth and Bank Loan Supply Shocks, Annual MSA-Level Data from 1999 to 2018

Dependent Variable: Annual log change in MSA young-firm employment share

\begin{tabular}{|c|c|c|c|c|c|c|}
\hline & (1) & (2) & (3) & (4) & (5) & (6) \\
\hline & OLS & OLS & IV & IV & IV & $\operatorname{IV}(\mathrm{S})$ \\
\hline Coefficient on log real & 0.199 & 0.189 & 0.314 & 0.308 & 0.352 & 0.211 \\
\hline Housing price change $(\beta)$ & $(0.019)$ & $(0.020)$ & $(0.073)$ & $(0.074)$ & $(0.083)$ & $(0.105)$ \\
\hline \multirow{2}{*}{ Coefficient on $S B L(\varphi)$} & & 0.021 & & 0.016 & 0.014 & 0.020 \\
\hline & & $(0.008)$ & & $(0.008)$ & $(0.008)$ & $(0.009)$ \\
\hline \multicolumn{2}{|l|}{ F-test for Excluded Instruments } & & 41.8 & 42.8 & 40.2 & 34.5 \\
\hline MSA Effects & Yes & Yes & Yes & Yes & Yes & Yes \\
\hline MSA Bartik Demand Control & No & No & No & No & Yes & Yes \\
\hline MSA Population Growth Rate & No & No & No & No & Yes & Yes \\
\hline
\end{tabular}

Notes: We use 4,660 observations in estimating each regression model. For additional notes, see the notes to Table 1 . 
Table 3. Local Employment Growth Rate Responses to Local Housing Price Growth and Bank Loan Supply Shocks, Annual MSA-Level Data from 1999 to 2018

A. Dependent Variable: Annual Growth Rate of Young-Firm Employment in MSA

\begin{tabular}{llll}
\hline & OLS & IV & IV \\
Coefficient on log real & 0.219 & 0.384 & 0.407 \\
Housing price change $(\beta)$ & $(0.019)$ & $(0.072)$ & $(0.078)$ \\
Coefficient on $S B L(\varphi)$ & 0.043 & 0.036 & 0.031 \\
& $(0.006)$ & $(0.007)$ & $(0.007)$
\end{tabular}

B. Dependent Variable: Annual Growth Rate of Mature-Firm Employment in MSA

\begin{tabular}{llll}
\hline & OLS & IV & IV \\
Coefficient on log real & 0.042 & 0.068 & 0.044 \\
Housing price change $(\beta)$ & $(0.008)$ & $(0.035)$ & $(0.034)$ \\
Coefficient on SBL $(\varphi)$ & 0.009 & 0.008 & 0.006 \\
& $(0.002)$ & $(0.003)$ & $(0.003)$ \\
& & & \\
\hline F-test for Excluded Instruments & & 42 & 40 \\
\hline MSA Effects & Yes & Yes & Yes \\
MSA Bartik Demand Control & No & No & Yes \\
MSA Population Growth Rate & No & No & Yes \\
\hline
\end{tabular}

Notes: Standard errors in parentheses, with clustering at the MSA level. All specifications include the change in the MSA-level unemployment rate and a quadratic in the national GDP growth rate as additional controls. For IV estimates, overidentification tests show we do not reject the null of instrument validity. 4,660 Observations. 
Table 4 MSA-Level Regressions from 1999-2018. Dependent variables: Log Change in Young-and Small-Firm Employment Shares

\begin{tabular}{|c|c|c|c|c|c|c|}
\hline & (1) & (2) & (3) & (4) & (5) & (6) \\
\hline & $\begin{array}{l}\text { Log Change } \\
\text { in Young- } \\
\text { Firm Share } \\
(\text { OLS) }\end{array}$ & $\begin{array}{l}\text { Log Change } \\
\text { in Young- } \\
\text { Firm Share } \\
\text { (IV) }\end{array}$ & $\begin{array}{l}\text { Log Change } \\
\text { in Young- } \\
\text { Firm Share } \\
\text { (IV) }\end{array}$ & $\begin{array}{l}\text { Log Change } \\
\text { in Small-Firm } \\
\text { Share (OLS) }\end{array}$ & $\begin{array}{l}\text { Log Change in } \\
\text { Small -Firm } \\
\text { Share (IV) }\end{array}$ & $\begin{array}{l}\text { Log Change in } \\
\text { Small-Firm } \\
\text { Share (IV) }\end{array}$ \\
\hline $\begin{array}{l}\text { Growth Rate in Real } \\
\text { Housing Price }\end{array}$ & $\begin{array}{l}0.189 \\
(0.020)\end{array}$ & $\begin{array}{l}0.308 \\
(0.074)\end{array}$ & $\begin{array}{l}0.352 \\
(0.083)\end{array}$ & $\begin{array}{l}0.052 \\
(0.008)\end{array}$ & $\begin{array}{l}0.131 \\
(0.037)\end{array}$ & $\begin{array}{l}0.150 \\
(0.041)\end{array}$ \\
\hline $\begin{array}{l}\text { Local Small Business } \\
\text { Loan Supply Shock }\end{array}$ & $\begin{array}{l}0.021 \\
(0.008)\end{array}$ & $\begin{array}{l}0.016 \\
(0.008)\end{array}$ & $\begin{array}{l}0.014 \\
(0.008)\end{array}$ & $\begin{array}{l}0.008 \\
(0.003)\end{array}$ & $\begin{array}{l}0.005 \\
(0.003)\end{array}$ & $\begin{array}{l}0.006 \\
(0.004)\end{array}$ \\
\hline $\begin{array}{l}\text { F-test for Excluded } \\
\text { Instruments }\end{array}$ & & 42.8 & 40.2 & & 42.8 & 40.2 \\
\hline
\end{tabular}

Notes: Standard errors in parentheses, with clustering at the MSA level. We control for MSA fixed effects in Columns (1) to (6) and the Bartik-like demand variable and population growth rate in Columns (3) and (6). 4,660 Observations. 
Table 5. MSA-Level Regressions from 1999-2018. Dependent variables: Annual Employment Growth Rate Differentials for Young Minus Mature and Small Minus Large Firms

\begin{tabular}{|c|c|c|c|c|c|c|}
\hline & (1) & (2) & (3) & (4) & (5) & (6) \\
\hline & $\begin{array}{l}\text { Young } \\
\text { Minus } \\
\text { Mature } \\
(\mathrm{OLS})\end{array}$ & $\begin{array}{l}\text { Young } \\
\text { Minus } \\
\text { Mature } \\
(\mathrm{IV})\end{array}$ & $\begin{array}{l}\text { Young } \\
\text { Minus } \\
\text { Mature } \\
\text { (IV) }\end{array}$ & $\begin{array}{l}\text { Small } \\
\text { Minus } \\
\text { Large } \\
(\mathrm{OLS})\end{array}$ & $\begin{array}{l}\text { Small } \\
\text { Minus } \\
\text { Large } \\
\text { (IV) }\end{array}$ & $\begin{array}{l}\text { Small } \\
\text { Minus } \\
\text { Large } \\
\text { (IV) }\end{array}$ \\
\hline $\begin{array}{l}\text { Growth in real housing } \\
\text { price }\end{array}$ & $\begin{array}{l}0.177 \\
(0.018)\end{array}$ & $\begin{array}{l}0.316 \\
(0.064)\end{array}$ & $\begin{array}{l}0.363 \\
(0.073)\end{array}$ & $\begin{array}{l}0.141 \\
(0.010)\end{array}$ & $\begin{array}{l}0.249 \\
(0.039)\end{array}$ & $\begin{array}{l}0.254 \\
(0.039)\end{array}$ \\
\hline $\begin{array}{l}\text { Local Small Business } \\
\text { Loan Supply Shock }\end{array}$ & $\begin{array}{l}0.033 \\
(0.007)\end{array}$ & $\begin{array}{l}0.028 \\
(0.007)\end{array}$ & $\begin{array}{l}0.025 \\
(0.007)\end{array}$ & $\begin{array}{l}0.005 \\
(0.003)\end{array}$ & $\begin{array}{l}0.000 \\
(0.003)\end{array}$ & $\begin{array}{l}0.001 \\
(0.003)\end{array}$ \\
\hline $\begin{array}{l}\text { F-test for Excluded } \\
\text { Instruments }\end{array}$ & & 42.8 & 40.2 & & 42.8 & 40.2 \\
\hline
\end{tabular}

Notes: Standard errors in parentheses, with clustering at the MSA level. We control for MSA fixed effects in Columns (1) to (6) and the Bartik-like demand variable and population growth rate in Columns (3) and (6). 4,660 Observations. 
Table 6. Testing the Age-Invariance Proposition: Industry-Level Log Employment Growth Response to Local House Price Growth, Annual Data from 1992 to 2018

Dependent Variable: Annual Log Employment Change at the MSA-Industry Level $\left(G R_{j m t}\right)$

$\begin{array}{lccc}(1) & (2) & (3) & (4) \\ \text { OLS } & \text { OLS } & \text { OLS } & \text { IV }\end{array}$

\begin{tabular}{|c|c|c|c|c|}
\hline $\begin{array}{l}\text { Change in Local Unemployment Rate } \\
\left(C Y C_{m t}\right)\end{array}$ & $\begin{array}{l}-0.81 \\
(0.099)\end{array}$ & & & $\begin{array}{l}-0.61 \\
(0.107)\end{array}$ \\
\hline Log Change in Local House Prices $\left(H P_{m t}\right)$ & $\begin{array}{l}0.116 \\
(0.010)\end{array}$ & & & $\begin{array}{l}0.245 \\
(0.040)\end{array}$ \\
\hline $\begin{array}{l}\text { Lagged Young-Firm Employment Share } \\
\left(\text { YoungSh }_{j m, t-1}\right)\end{array}$ & $\begin{array}{l}0.030 \\
(0.005)\end{array}$ & $\begin{array}{l}0.032 \\
(0.006)\end{array}$ & $\begin{array}{l}0.018 \\
(0.006)\end{array}$ & $\begin{array}{l}0.028 \\
(0.005)\end{array}$ \\
\hline Interaction Term $\left(H P_{m t} *\right.$ YoungSh $\left.h_{j m, t-1}\right)$ & $\begin{array}{l}0.674 \\
(0.054)\end{array}$ & $\begin{array}{l}0.683 \\
(0.066)\end{array}$ & $\begin{array}{l}0.419 \\
(0.076)\end{array}$ & $\begin{array}{l}0.949 \\
(0.094)\end{array}$ \\
\hline R-squared Value & 0.079 & 0.147 & 0.184 & 0.077 \\
\hline MSA Fixed Effects & Yes & No & No & Yes \\
\hline Year Fixed Effects & Yes & No & No & Yes \\
\hline Industry Fixed Effects & Yes & Yes & No & Yes \\
\hline MSA-by-Year Fixed Effects & No & Yes & Yes & No \\
\hline Industry-by-Year Fixed Effects & No & No & Yes & No \\
\hline
\end{tabular}

Notes: The sample, which covers 233 MSAs and 14 industries, contains 87,576 observations at the industry-MSA level from 1992 to 2018. We drop cells with no employment. See text for list of industries. Column (4) instruments for $H P_{m t}$ and the interaction term using the IV approach used in Tables 1 and 2. Standard errors in parentheses, with clustering at the MSA level. 
Table 7. Quantifying the Departures from Age Invariance

\section{A. Dispersion in Young-Firm Employment Shares Across Local Industries}

\begin{tabular}{llll}
\hline Industry-MSA Young-Firm Share & $1992-2018$ & Boom Period & Bust Period \\
90th Percentile & 1.450 & 1.447 & 1.387 \\
10th Percentile & 1.065 & 1.081 & 1.063 \\
Standard Deviation & 0.156 & 0.149 & 0.132 \\
90-10 Difference & 0.385 & 0.367 & 0.323
\end{tabular}

B. Dispersion in Annual MSA-Level Log House Price Changes

\begin{tabular}{llll}
\hline Log MSA House Price Change & $1992-2018$ & Boom Period & Bust Period \\
90th Percentile & 0.061 & 0.088 & 0.036 \\
10th Percentile & -0.044 & -0.002 & -0.123 \\
Standard Deviation & 0.054 & 0.043 & 0.077 \\
90-10 Difference & 0.105 & 0.090 & 0.159
\end{tabular}

C. Calculating the Departures from Age Invariance, Using $\hat{\boldsymbol{c}}=\mathbf{0 . 9 4 9}$

\begin{tabular}{lllll}
\hline & \multicolumn{2}{c}{ Boom Period } & \multicolumn{2}{c}{ Bust Period } \\
$H P(p)$ from Panel B & P90 & P10 & P90 & P10 \\
Average Annual Log Changes & 0.088 & -0.002 & 0.036 & -0.123 \\
YoungSh & \multicolumn{2}{c}{0.367} & \multicolumn{2}{c}{0.323} \\
Response Differential Per Equation (8) & \multicolumn{2}{c}{0.367} \\
$\quad$ Annual, Percentage Points & 3.1 & -0.1 & 1.1 & -3.8 \\
$\quad$ Cumulative, Percentage Points & 12.8 & 0.3 & 3.3 & -10.9 \\
\hline
\end{tabular}

Notes: Panel $\mathrm{C}$ implements the calculation expressed in equation (8) in the main text. $\hat{\boldsymbol{c}}$ is the coefficient for the interaction term from column 4 of Table 6. Panels A and B report inputs to the calculation and related summary statistics. The Boom Period runs from 1998 to 2006, and the Bust Period runs from 2007 to 2010. 


\section{Appendices Not Intended for Publication}

\section{Appendix A: Measurement of Young Firm Dynamics in the BDS}

The Business Dynamic Statistics (BDS) reports tabulations from the Census Longitudinal Business Database (LBD). The LBD is a longitudinal establishment-level database with establishment and firm-level characteristics. Firms are defined based on operational control. As described in section II, firm age is based on the age of the oldest establishment when a new legal entity originates. Establishment-level net employment growth rates underlying the BDS tabulations use the Davis, Haltiwanger and Schuh (1996) (DHS) growth rate measure:

$$
g_{e t}=\left(\frac{E_{e t}-E_{e t-1}}{X_{e t}}\right), \quad X_{e t}=0.5 *\left(E_{e t}+E_{e t-1}\right)
$$

where $e$ indexes establishments and $t$ indexes years. The DHS growth rate measure is a $2^{\text {nd }}$ order approximation of the log first difference, is bounded between -2 and 2 , and accommodates zeros in $t$ (exit) or $t-1$ (entry). The employment at the establishment-level in the LBD in year $t$ is the number of employees of workers on the payroll for the payroll period including March $12^{\text {th }}$. As such the net employment growth rates (and all change measures in the LBD and BDS) represent changes from March in $t-1$ to March of $t$.

The net employment growth rate for establishments classified into a cell $S$ in $t$ (e.g., a firm age and state cell) is given by:

$$
g_{s t}=\sum_{e \in s} \frac{X_{e s t}}{X_{s t}} g_{e s t}
$$

where $S$ is the characteristics of the establishment in year t. The BDS provides net employment growth rate statistics as well as the decomposition into job creation, job destruction (by continuing, entering and exiting establishments) by a wide range of cells $S$ defined by industry, firm age, firm size, establishment age, establishment size, and geographic cells defined by state and MSA. The BDS also reports these changes in terms of levels as well as the levels of employment and number of firms in each of classification cells.

For any given classification into cells of type $S$, the aggregate net employment growth is defined as the employment-weighted average of the cell based growth rates:

$$
g_{t}=\sum_{s} \frac{x_{s t}}{x_{t}} g_{s t}
$$


Relating the above measurement concepts to the measures from the BDS used in the paper, Figures B3 and B5 exploit the BDS net employment growth rate statistics defined by firm age (specifically, we use broad firm age categories as described in section II). The measures used in these figures capture within firm age group net employment growth rates. While instructive, such within firm age group net growth rates don't permit a characterization of the changing composition of employment by firm age (and likewise the changing composition of firms by firm age). For the latter, we use the share of young firm employment and the share of young firms as described in the main text. These can be directly measured from the BDS since the number of employees and firms are reported for all classifications in the BDS. Section III includes discussion of how the changing employment by firm age is related to net change within firm age groups and the changing composition.

Firm age is censored in the BDS given that firm and establishment age cannot be determined for establishments that exist in 1976 (the first year of the LBD). This implies that in each year subsequent to 1976 more firm age categories can be defined. We use two broad age categories in most of the analysis: young (firm age 0-5) and mature (6+). Firm age 0 in a given year reflects a parent firm that has all new establishments in that reference year. Firm ages naturally for subsequent ages.

Much of our statistical analysis commences in 1992 or later where it is straightforward to compute directly directly the employment of young firms (less than six years old), log changes in the young-firm employment share and net differentials for young minus mature firms. For descriptive statistics (e.g., Figure 1) and some counterfactual exercises we commence the analysis starting in 1981. Given our definition of young (less than six years old), the young-firm share is readily computable in 1982 and the log change in 1983. Given the focus on cyclical episodes in our analysis, it is advantageous to include statistics starting in 1981. In 1980, the BDS yields the employment of firms less than four years old directly, but to measure the employment of firms less than six years old in 1980 we need an estimate of employment at firms age $=4$ and age $=5$ in 1980 . We impute the latter in 1980 using the product of the share of employment of age $=4$ year old firms in 1982 and total employment in 1980. This imputation is feasible at the national, state and MSA levels of aggregation. Similar remarks apply to calculations for 1981. We note that these imputations are not critical for our results as the regression analysis commences in 1992 and later years. Moreover, these imputations have no impact on the depiction of the summary statistics from 1983 forward. 


\section{Appendix B: Supplemental Figures and Tables}

Figure B1. Firm Startup and Exit Rates, 1981 to 2018

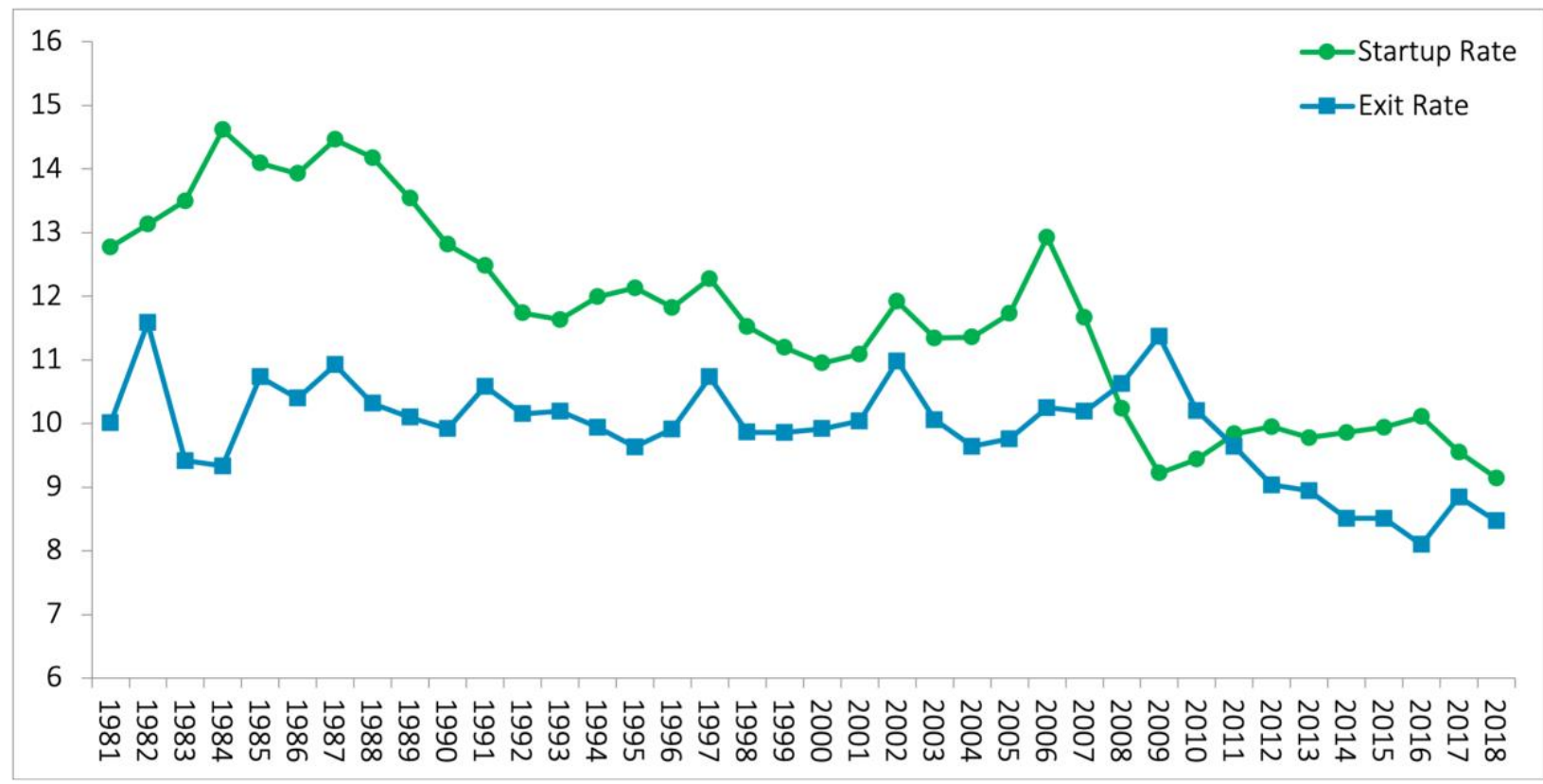

Figure B2. Share of Firms that are Young (<6 years old), 1981 to 2018

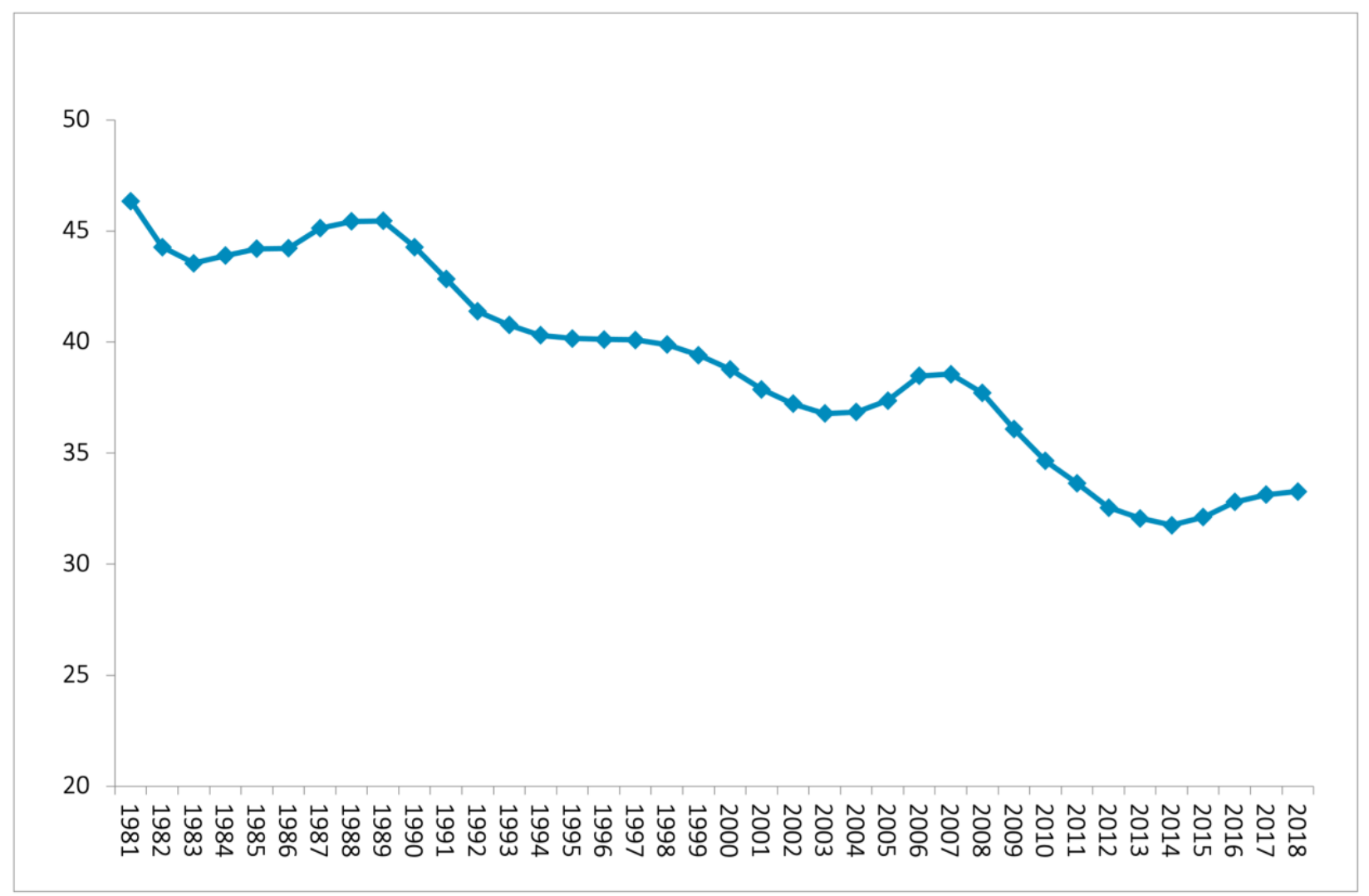


Figure B3. Annual Net Employment Growth Rates for Young and Mature Firms, 1981-2018

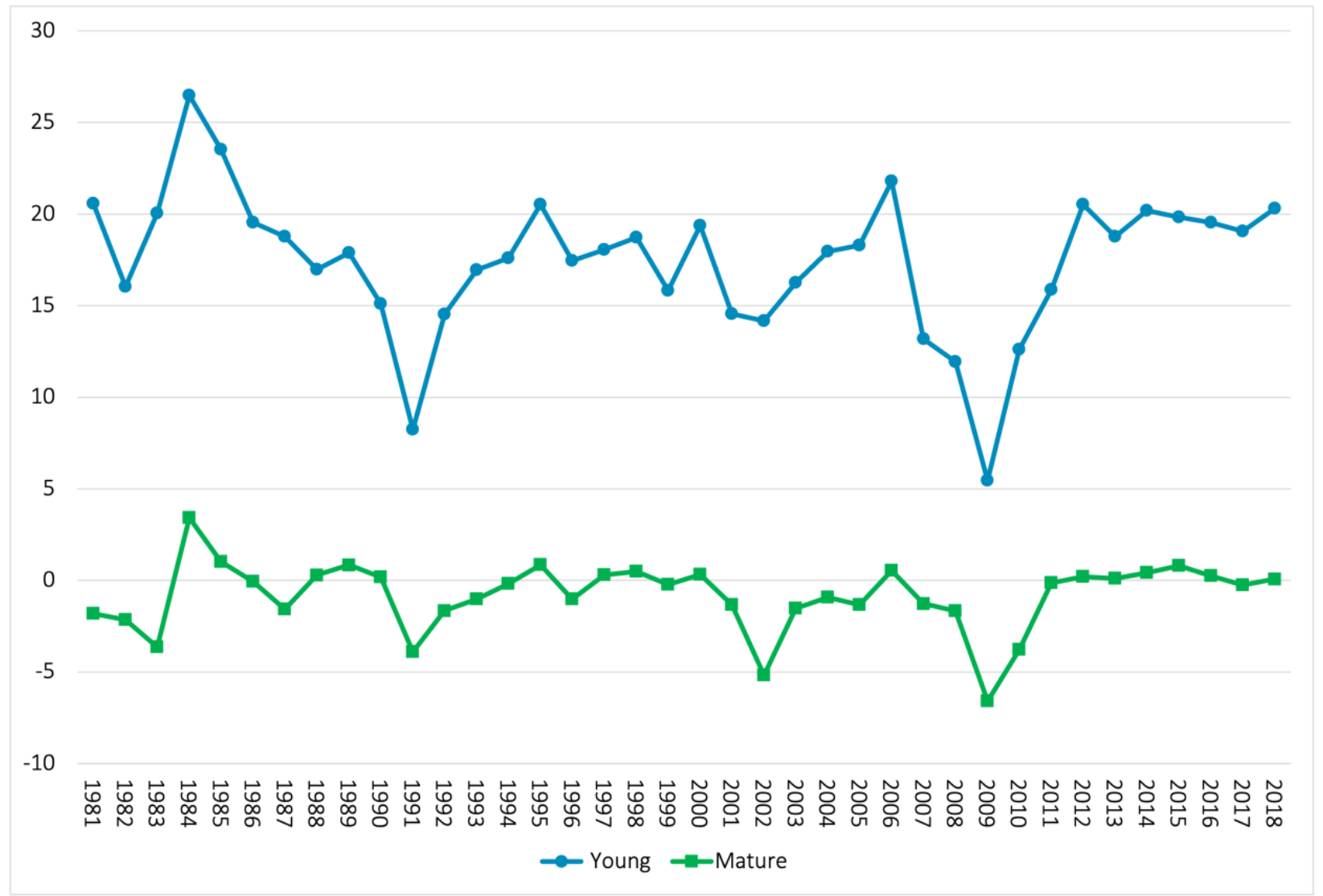

Notes: For each age group, the figure shows the employment-weighted DHS net growth rate from March of the previous year to March of the year reported on the horizontal scale. Net growth is inclusive of entry and exit of establishments. 
Figure B4. Cyclicality of Log Changes in the Young-Firm Share of Firms

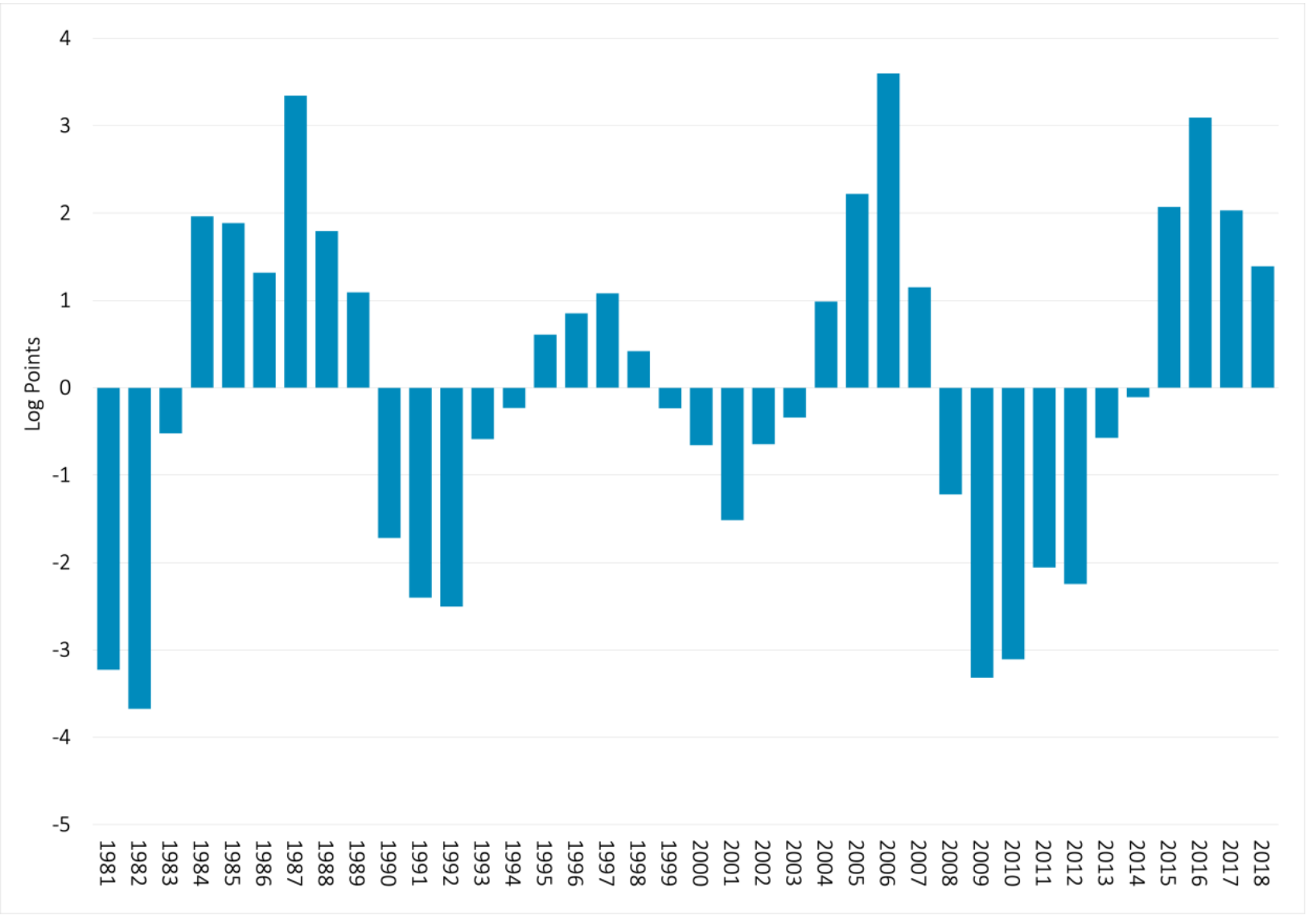

Notes: Each bar shows the annual average log change in the share of private sector firms that are young, deviated about the sample mean of minus $1.1 \log$ change. See notes to Figures 1 and 2 for additional information. 
Figure B5. Cyclicality of the Net Growth Rate Differential Between Young and Mature Firms

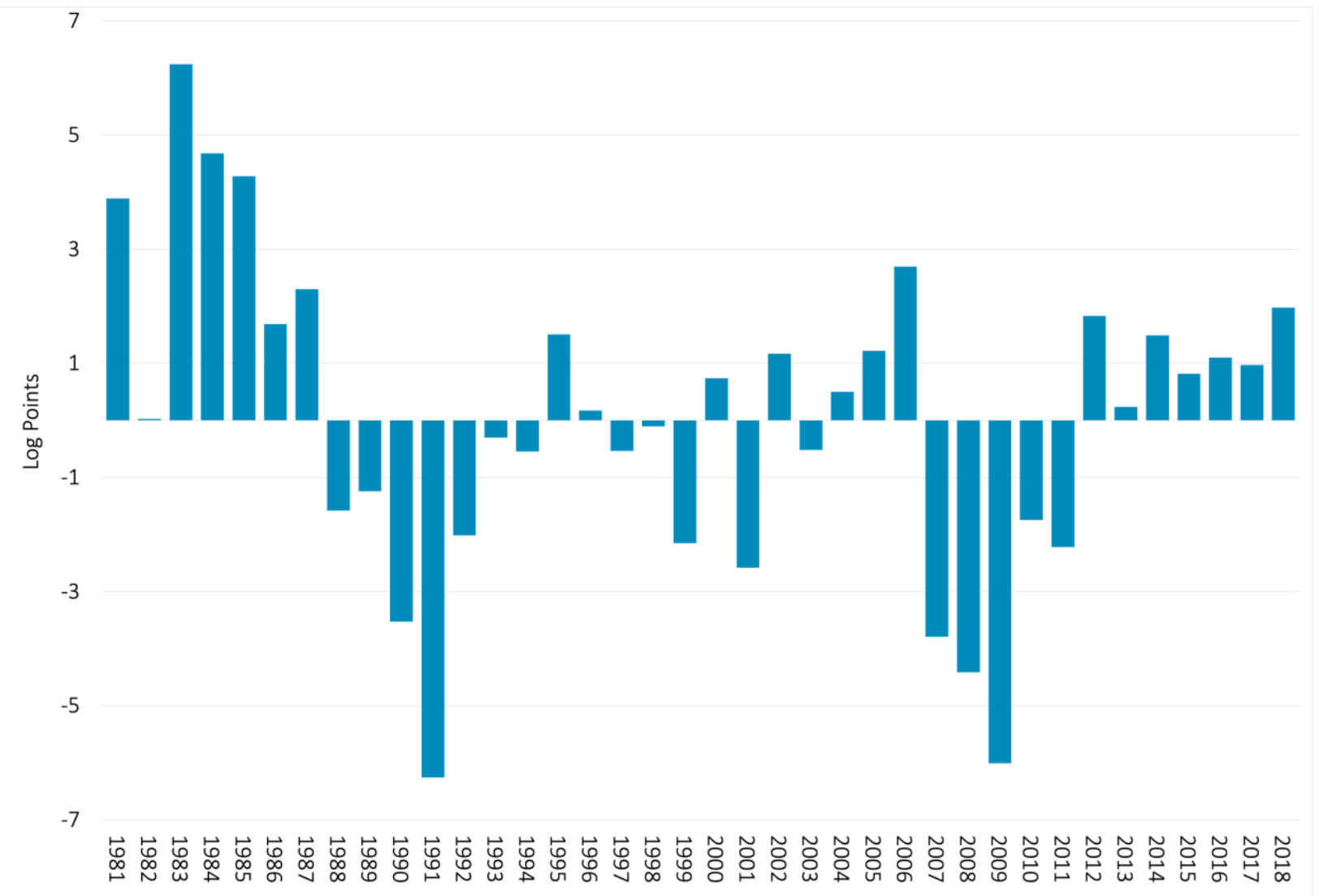

Notes: Each bar shows the annual average net employment growth differential between young and mature firms, deviated about the sample mean net differential of 18.2 log change. See notes to Figures 1 and 2 for additional information. 
Figure B6A: Relationship Between Log Difference in Young-Firm Employment Share and the Change in the Unemployment Rate, State by Year Cells, 1981-2018

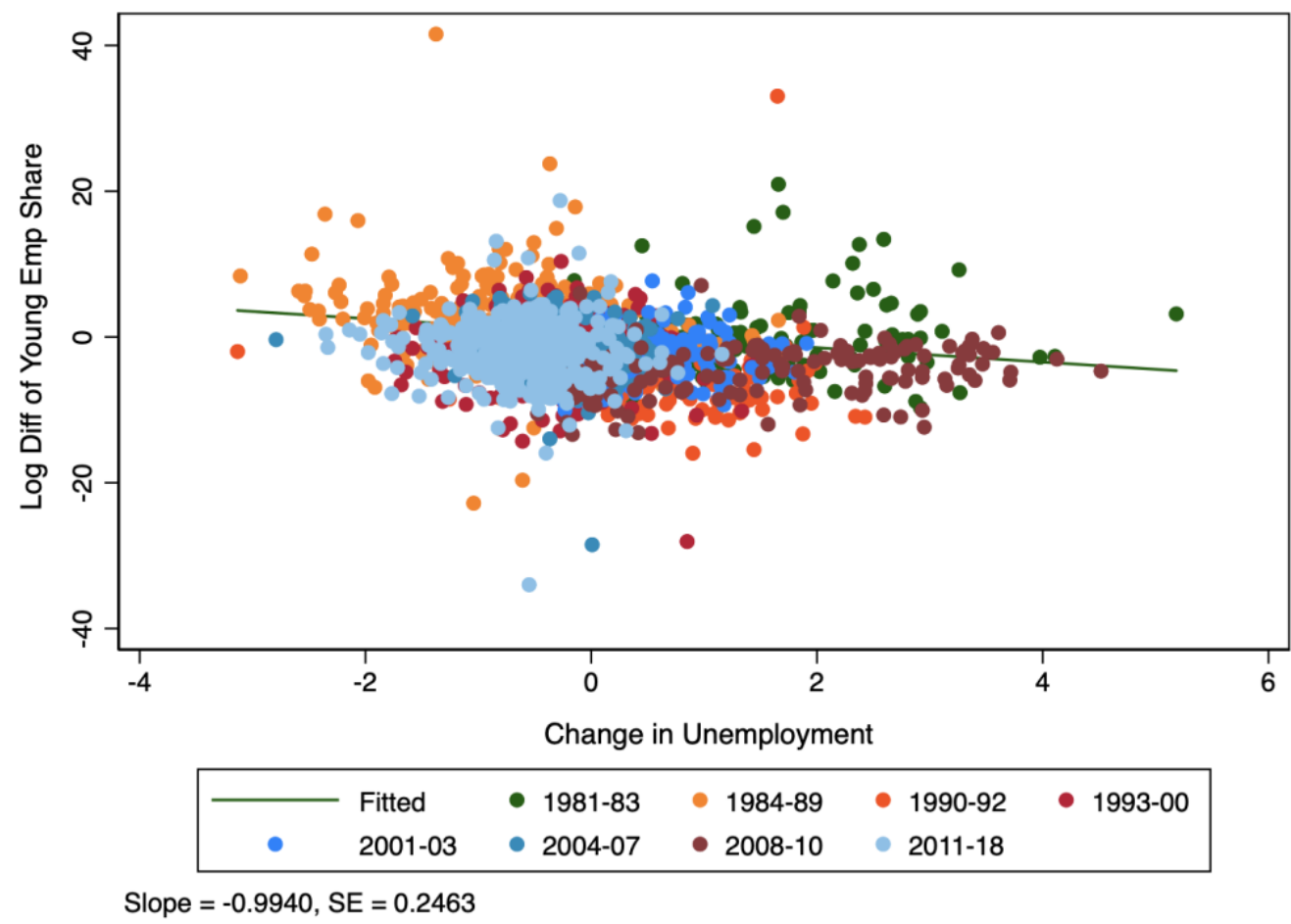

Figure B6B: Relationship Between Log Difference in Young Employment Share and Growth Rate of Real Housing Price, State by Year Cells, 1981-2018

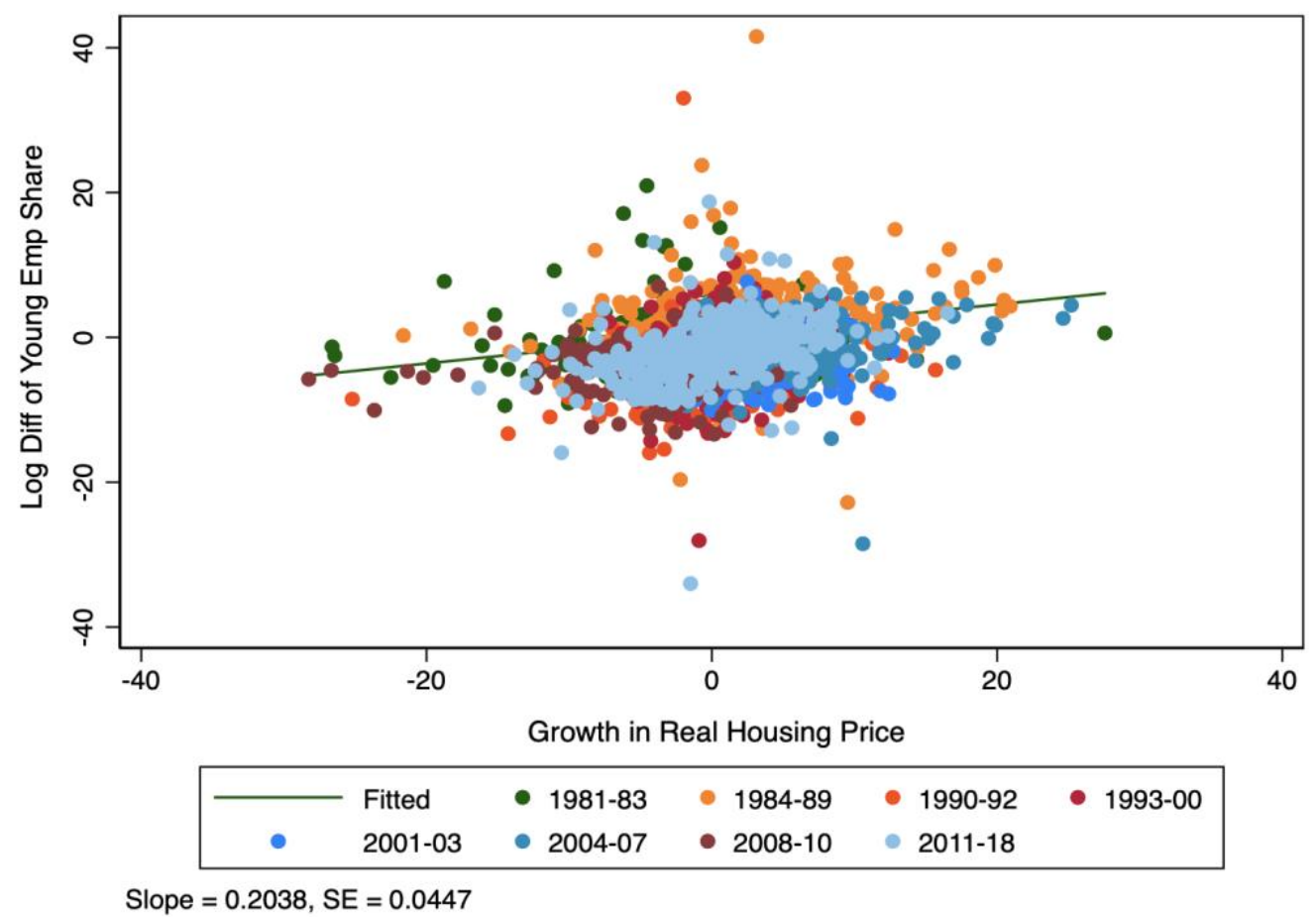

Notes: In Panel A, the scale is in log points on the vertical axis and percentage points on the horizontal axis. In Panel B, the scale is log points on both axis. See notes to Figure 2 for the timing convention of reported intervals. 
Figure B7. Relationship between Real Housing Price Growth in Boom (1998-2006) and Bust (2007-10) periods, MSA-Level Data

A. Boom

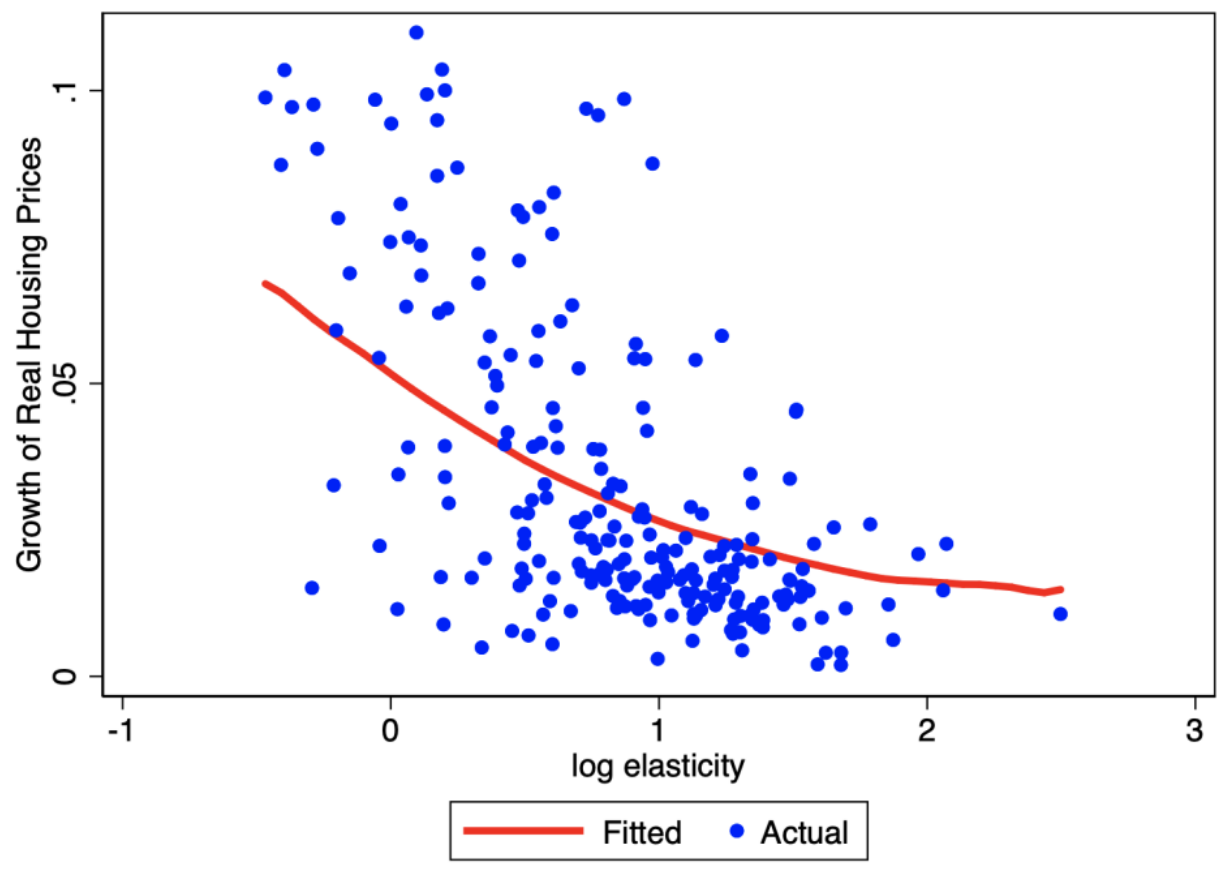

B. Bust

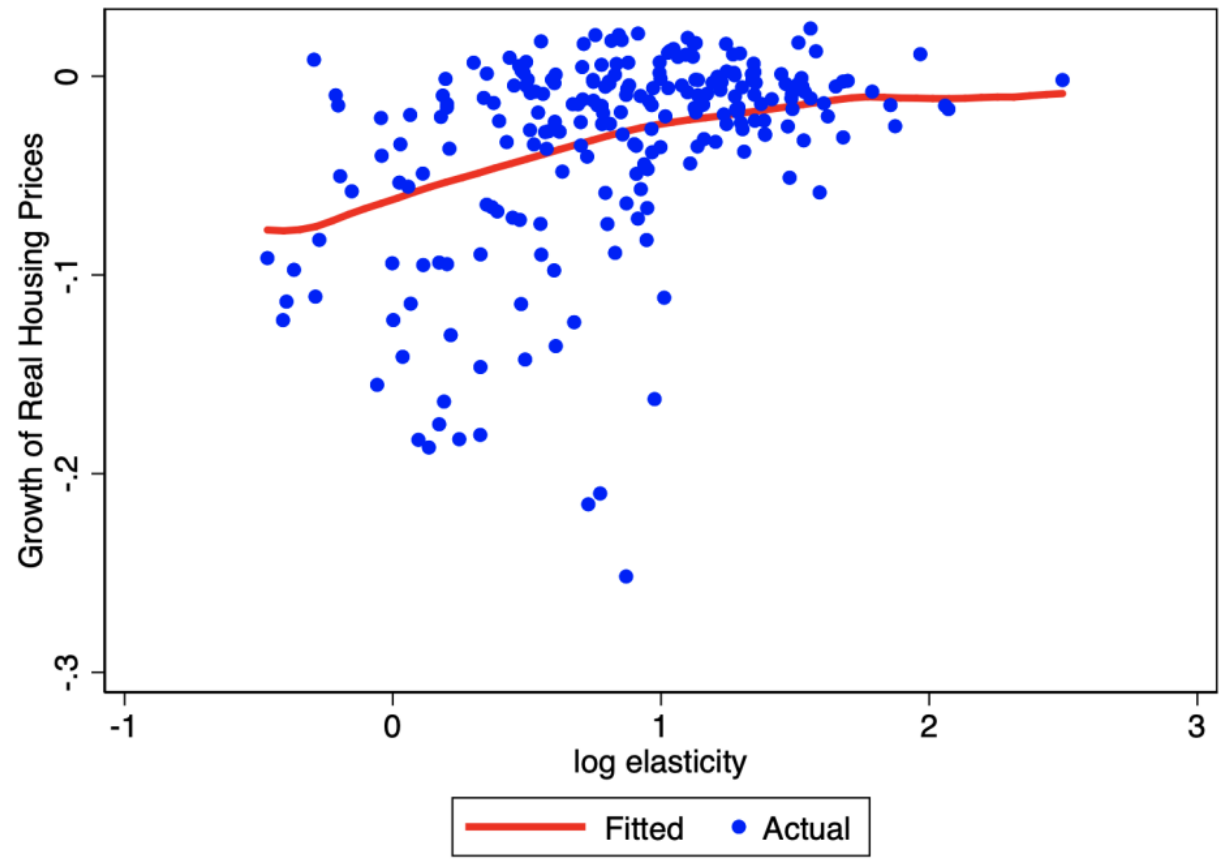

Notes: The vertical scale is the average annual MSA-level log change during the indicated period. The fitted line is a locally smoothed polynomial. 
Figure B8: Relationship Between Log Difference in Young-Firm Employment Share and Growth Rate of Real Housing Prices, MSA-level by Year (Bin Scatter)

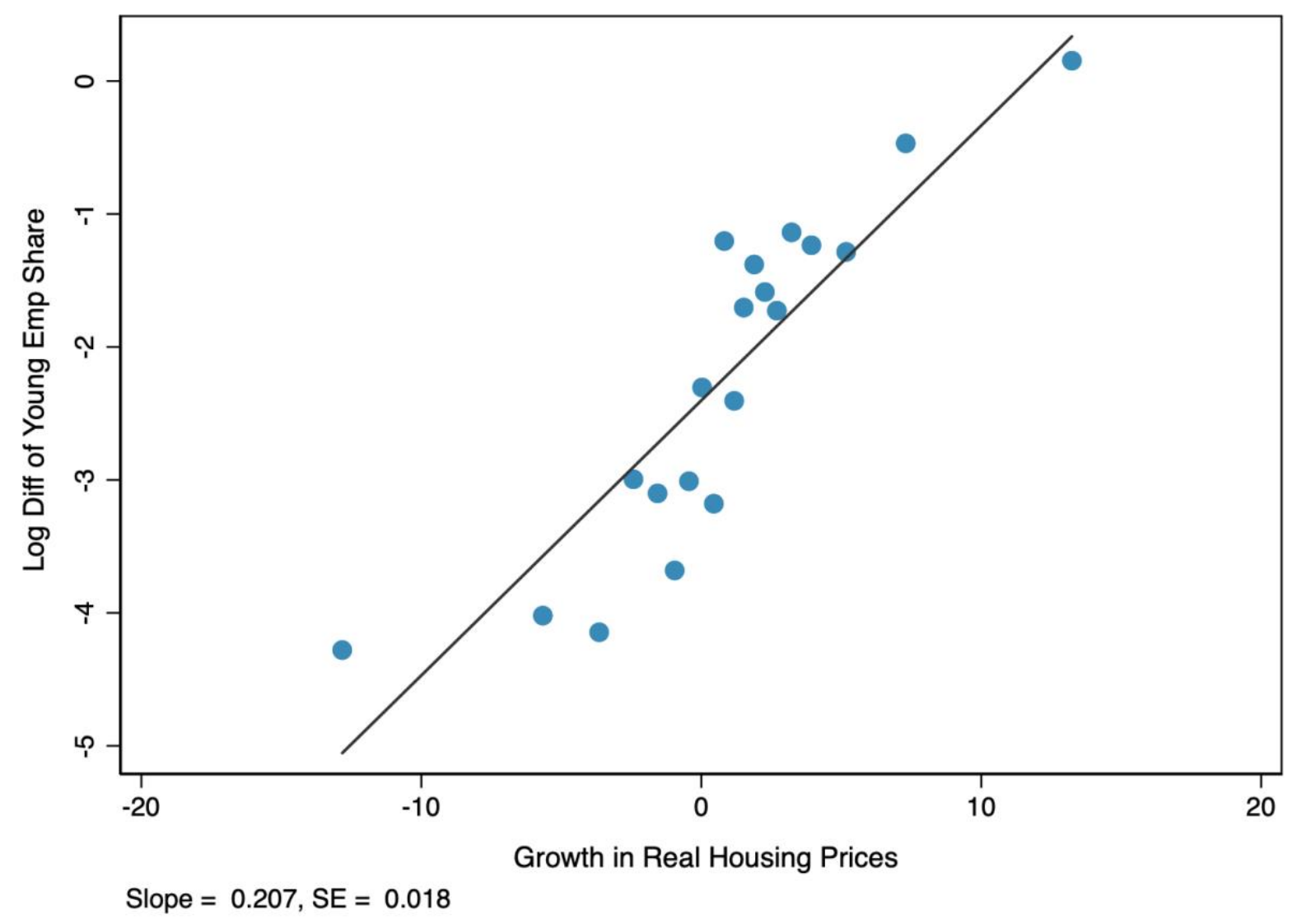

Notes: This chart shows a bin scatter of the raw data displayed in Figure 4. 
Figure B9 Relationship between Saiz and Price Sensitivity Housing Supply Elasticities

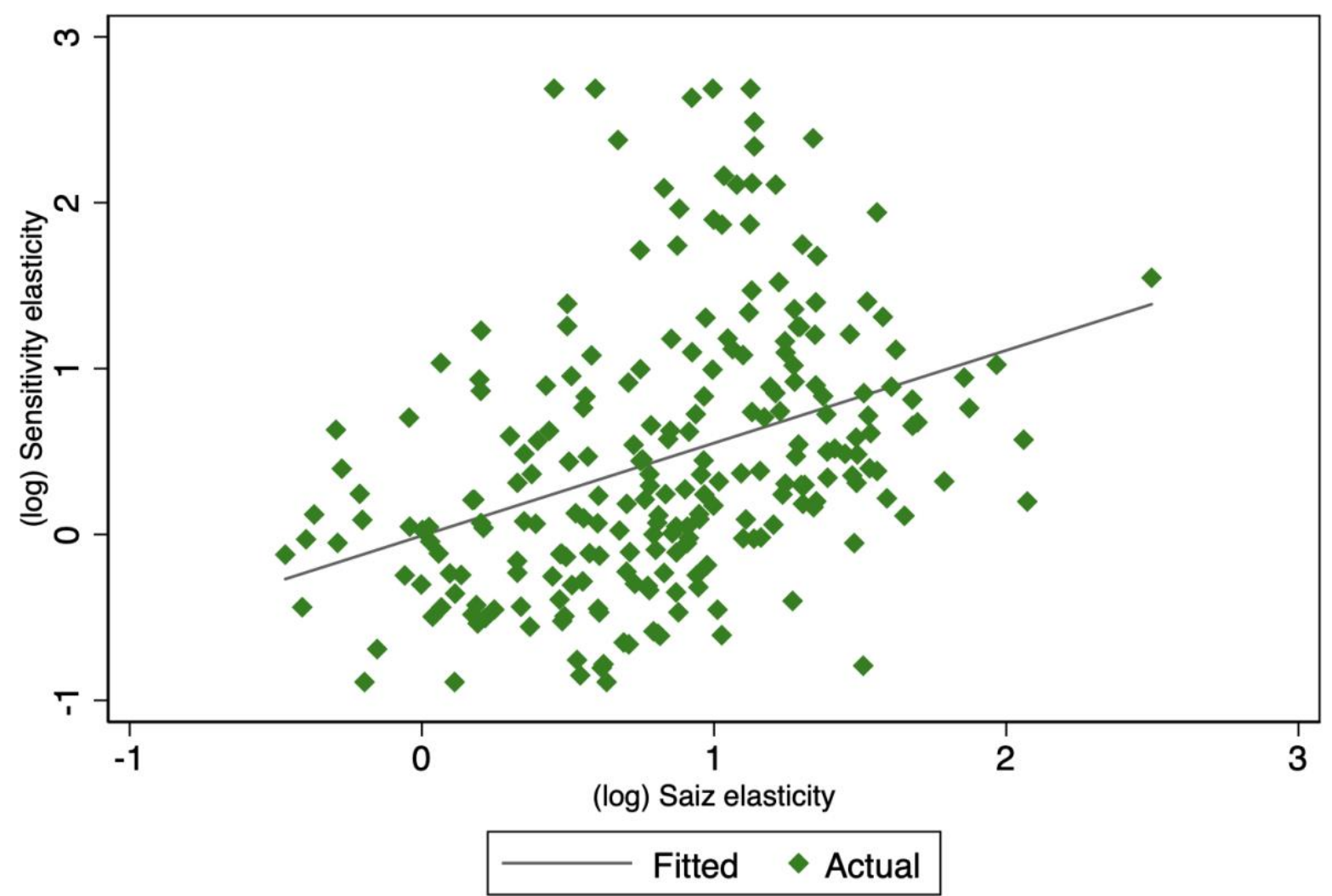

Slope $=0.5588$, SE $=0.092$ 
Figure B10: Relationship Between Log Difference in Young-Firm Employment Share and Growth Rate of Real Housing Prices, MSA-level data in Boom and Bust Periods

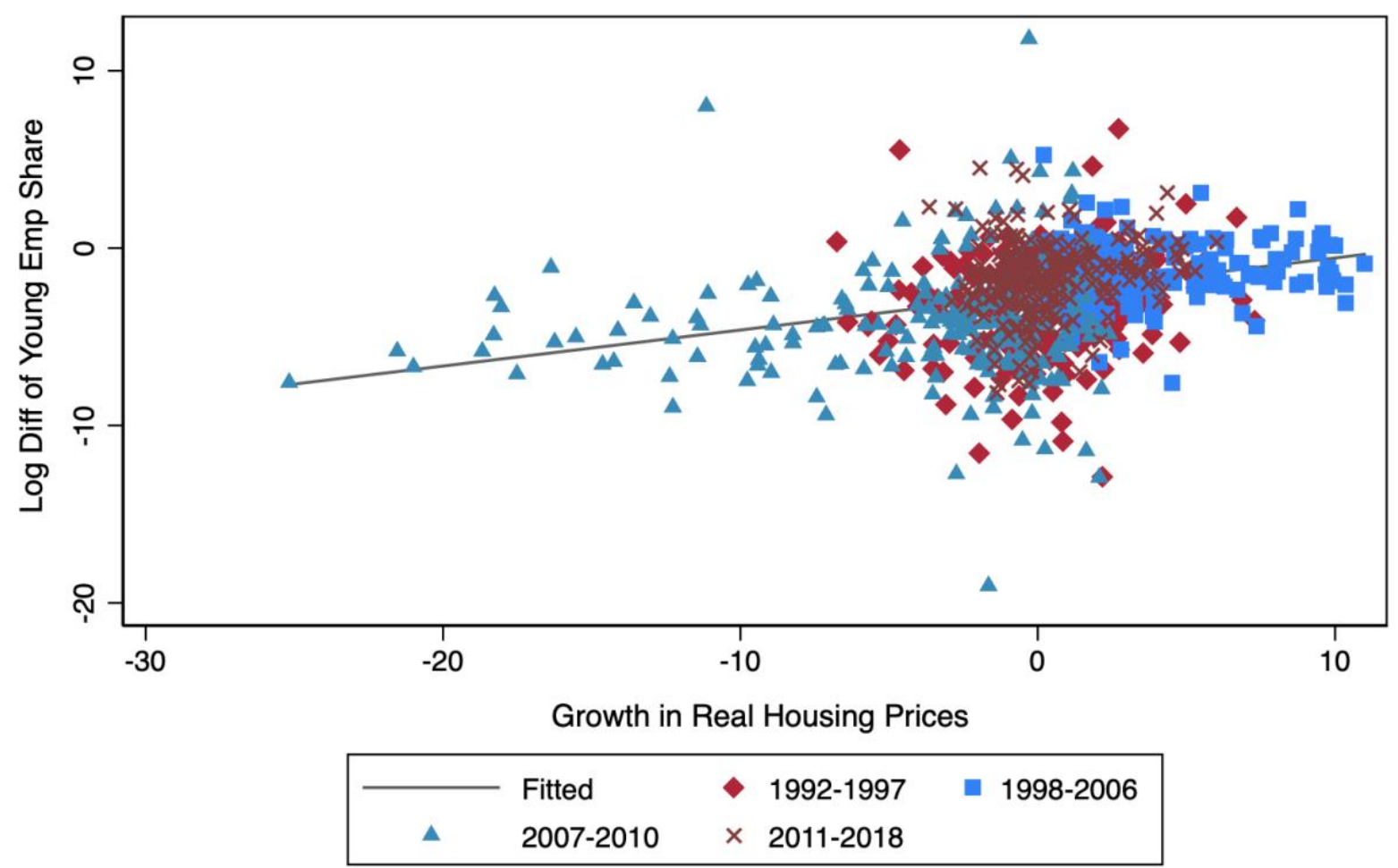

Slope $=0.203, \mathrm{SE}=0.021$

Mean Growth Rate of Housing Prices:

Full Sample $=0.192,1992-1997=0.4951998-2006=3.281,2007-2010=-3.349,2011-2018=0.344$ 
Figure B11: Second-Stage Relationship Between the Log Change in the Local Young-Firm Employment Share and the IV-Predicted Real Growth Rate of Local Housing Prices

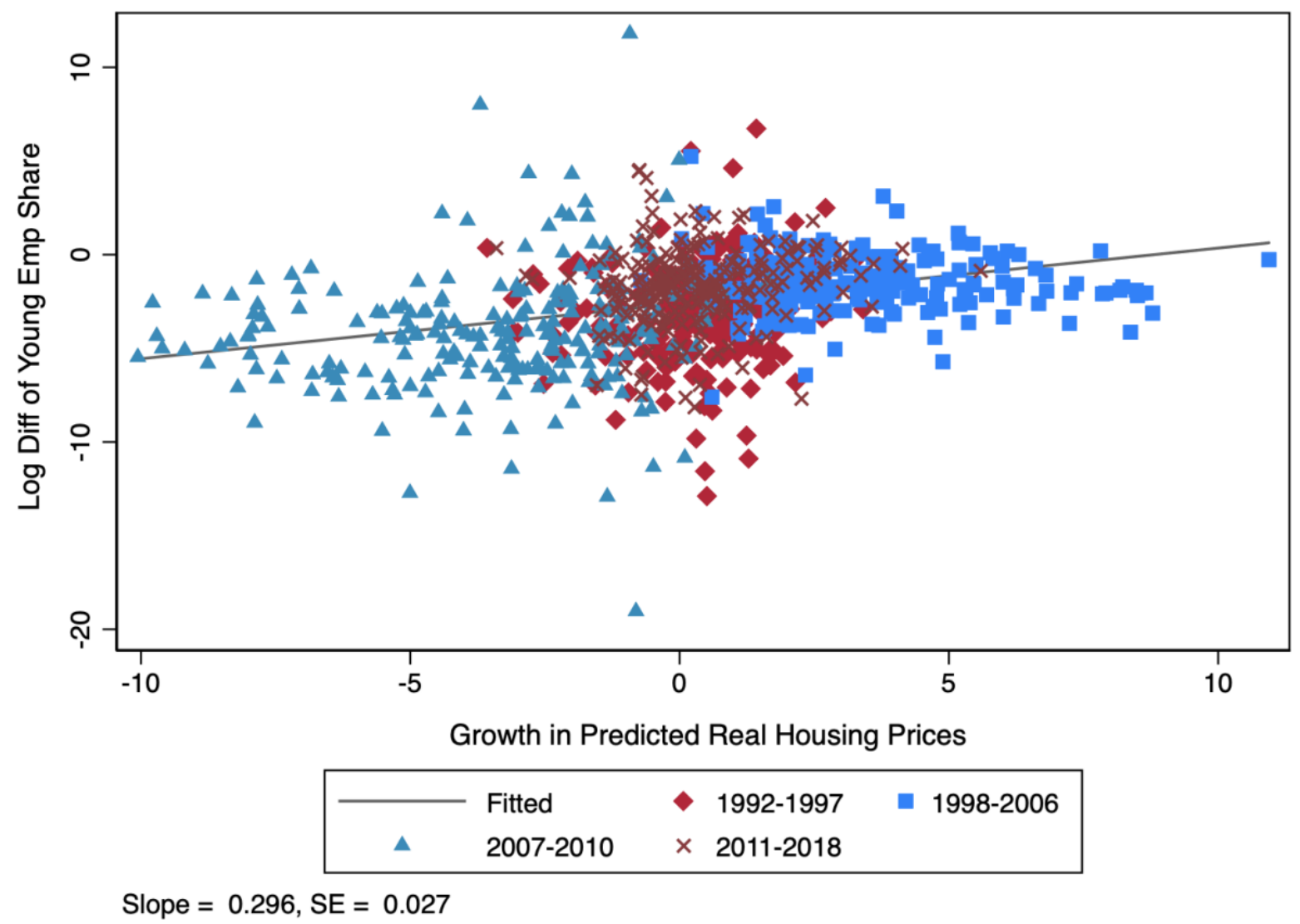

Notes: This figure reflects the estimated specification reported in Column (2) of Table 1. See Table 1 for the appropriately adjusted standard error. The analogous figure for Column (4) is very similar. 
Figure B12. Share of Employment at Small Firms, 1981-2018, U.S. Nonfarm Private Economy

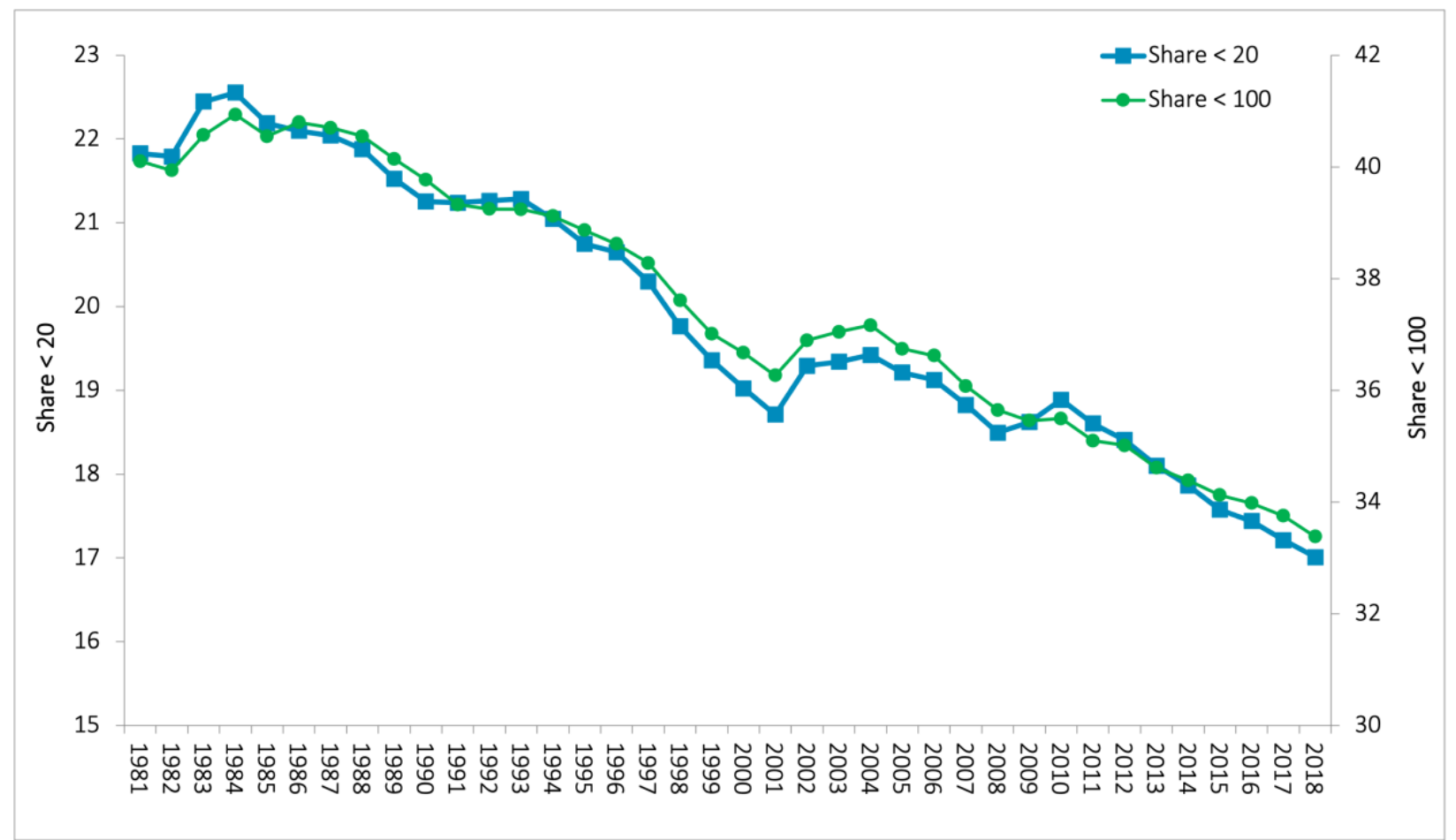


Figure B13. Log Differences in Employment Share of Small Firms by Cycle Episode

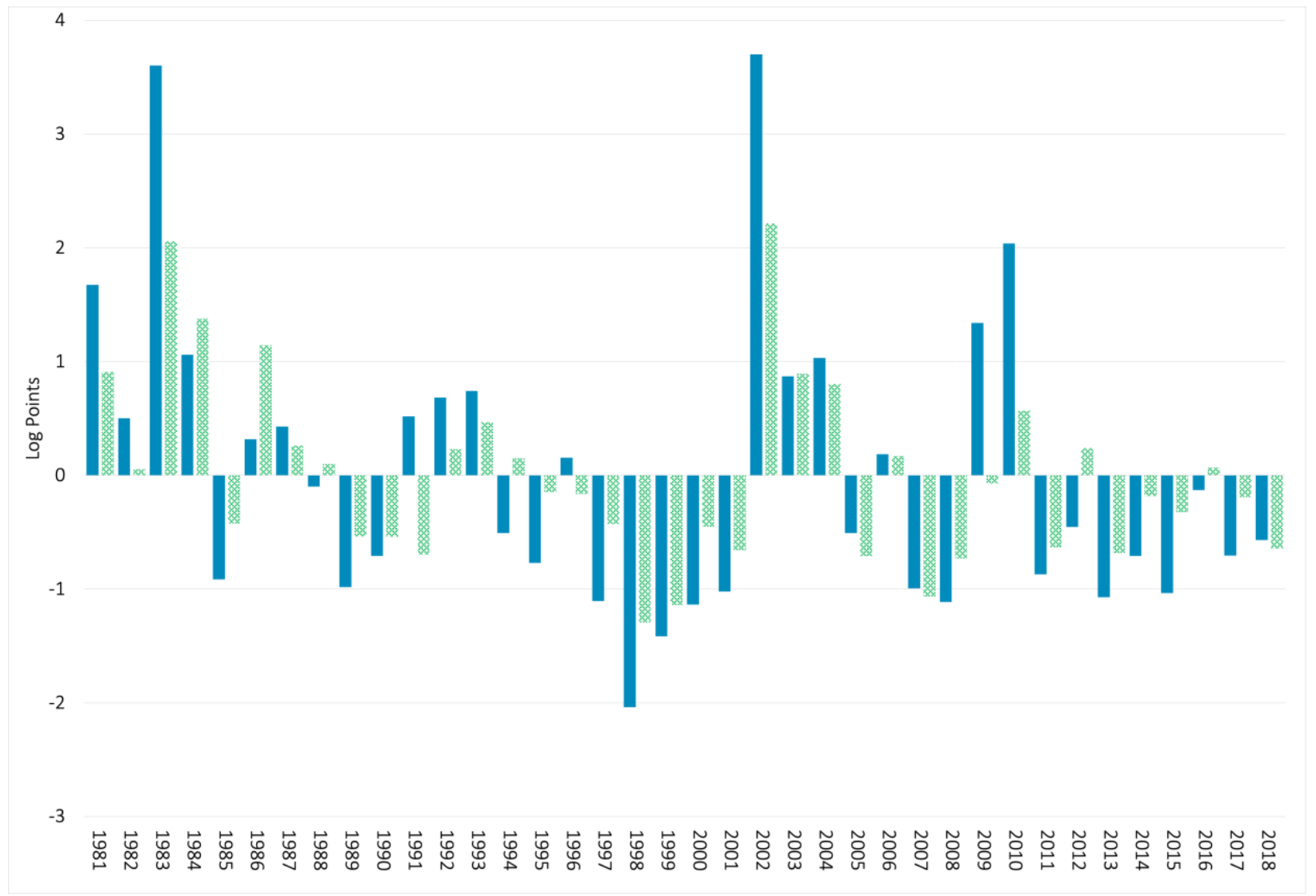

Notes: Sold (blue) Bar is Actual for small firms less than 20, Dotted (green) Bar is Actual for small firms less than 100. Annualized deviations from overall mean of minus 0.6 (less than 20) and 0.5 (less than 100) log change depicted. 
Figure B14. Log Differences in Employment Share of Small Firms (Less than 20), Actual and Predicted

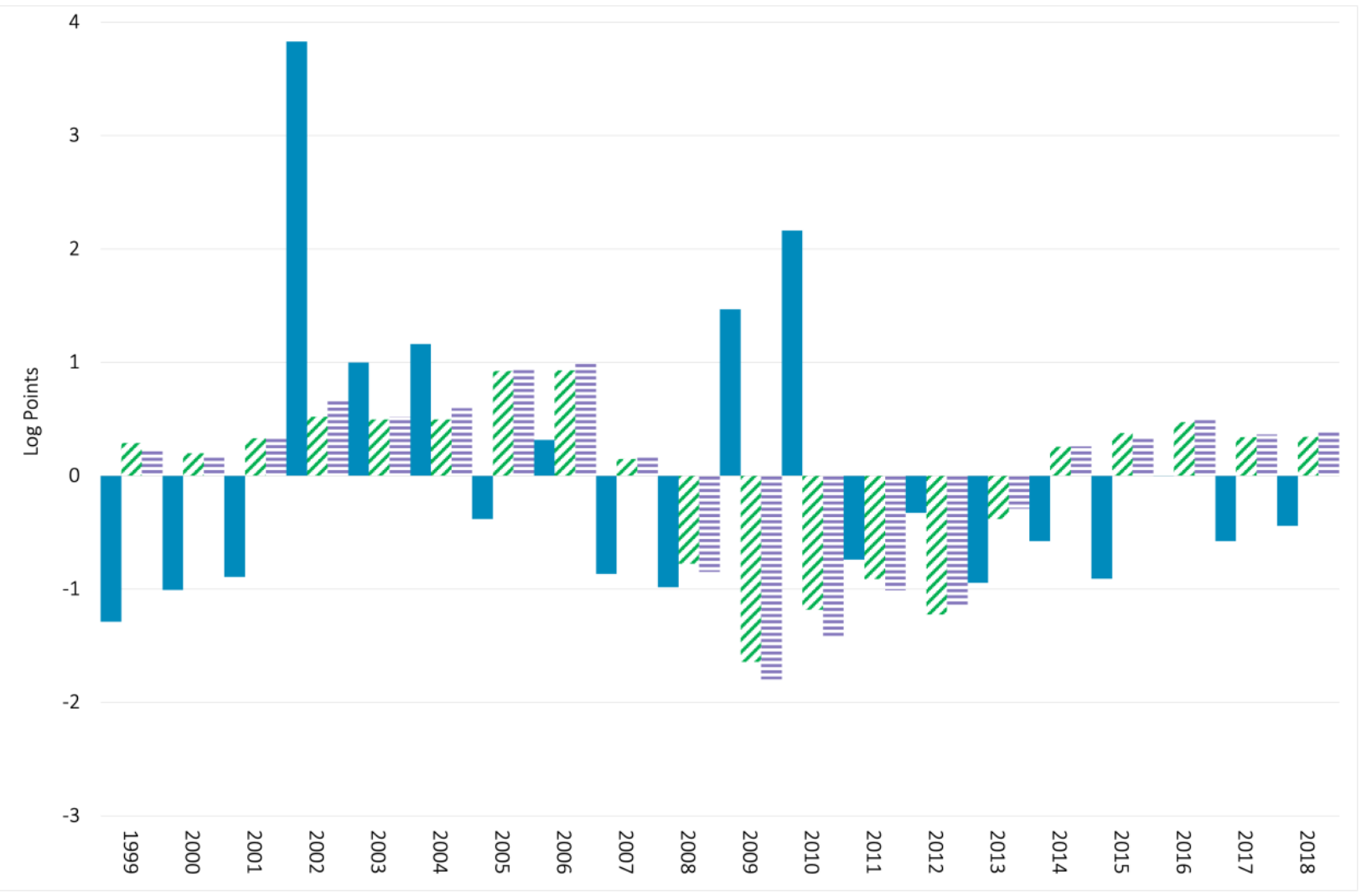

Notes: Sold (blue) Bar is Actual, Diagonal Striped (green) Bar is Counterfactual (Housing Prices only), Horizontal Striped (orange) Bar is (Housing Prices + Loan Supply). Using IV estimates from last column of Table B3. Annualized deviations from overall mean of minus $0.8 \mathrm{log}$ change depicted. 
Table B1. Coefficient Estimates on Cubic Polynomial of the Saiz Measure of Housing Supply Elasticities in the First Stage Specifications of the IV Regression Models

\begin{tabular}{lllll}
\multicolumn{1}{c}{ Coefficient on: } & \multicolumn{4}{c}{ Specification } \\
\cline { 2 - 5 } & $(2)$ & $(2)$ & $(6)$ & $(6)$ \\
\hline Log(Elasticity)*Chg_MSA_UR & 1.541 & 1.245 & 1.581 & 1.323 \\
& $(0.570)$ & $(0.650)$ & $(0.708)$ & $(0.798)$ \\
$\left(\log \left(\right.\right.$ Elasticity)) ${ }^{2 *}$ Chg_MSA_UR & 1.515 & 1.517 & 2.108 & 2.081 \\
& $(0.809)$ & $(0.856)$ & $(0.995)$ & $(1.063)$ \\
$\left(\log (\text { Elasticity) })^{3 *}\right.$ Chg_MSA_UR & -0.752 & -0.691 & -0.989 & -0.927 \\
& $(0.317)$ & $(0.313)$ & $(0.388)$ & $(0.390)$ \\
\hline MSA Bartik Demand Control & No & Yes & No & Yes \\
MSA Population Growth Rate & No & Yes & No & Yes \\
\hline
\end{tabular}

Notes: Table entries are estimated coefficients on $C Y C_{m t} Z_{m}^{\prime}$ in the first-stage regressions (2) and (6), as indicated. In addition to the controls indicated in the bottom two rows of the table, the first-stage specifications include MSA effects, year effects, and local cycle controls (the MSAlevel change in the unemployment rate). We cluster errors at the MSA level in computing standard errors. 
Table B2. Young-Firm Employment Share Response to Local Housing Price Growth, Adapting the IV Approach of Mian and Sufi by Collapsing the MSA-level Data Stacked within Four Periods and Stacking It Over the Periods

Dependent Variable: Average annual log change in MSA young-firm employment share during the period

\begin{tabular}{lllll}
\hline & $(1)$ & $(2)$ & $(3)$ & $(4)$ \\
& OLS & IV & OLS & IV \\
\hline $\begin{array}{l}\text { Coefficient on log real } \\
\text { housing price change }(\beta)\end{array}$ & 0.100 & 0.138 & 0.098 & 0.141 \\
F-Test for Excluded Instruments & & $(0.025)$ & & \\
& & 23.1 & & 20.4 \\
\hline Period Effects & Yes & Yes & Yes & Yes \\
\hline MSA Effects & No & No & Yes & Yes \\
\hline$R^{2}$ & 0.172 & 0.170 & 0.271 & 0.186 \\
Observations & 932 & 932 & 932 & 932 \\
\hline
\end{tabular}

Notes: We estimate specifications (D.2) and (D.3) from Appendix D using MSA-level data for four periods: 1992-97, 1998-06, 2007-10, and 2011-18. To construct instruments for MSA-level changes in housing prices, we interact period effects with a cubic polynomial in the log of the Saiz measure of the MSA housing supply elasticity. Robust standard errors in parentheses. 
Table B3. Young-Firm Employment Share Response to Local Housing Price Growth, Adapting the IV Approach of Mian and Sufi and Adding More Controls

Dependent Variable: Average annual log change in MSA young-firm employment share in the period

\begin{tabular}{lllll}
\hline & $(1)$ & $(2)$ & $(3)$ & $(4)$ \\
& IV & IV & IV & IV \\
\hline $\begin{array}{l}\text { Coefficient on log real } \\
\text { housing price change }(\beta)\end{array}$ & 0.141 & 0.147 & 0.147 & 0.131 \\
& $(0.048)$ & $(0.059)$ & $(0.058)$ & $(0.061)$ \\
F-Test for Excluded Instruments & 20.4 & 17.4 & 17.4 & 15.3 \\
& & & & \\
\hline Period \& MSA Effects & Yes & Yes & Yes & Yes \\
$\begin{array}{l}\text { MSA Unemployment Rate Change } \\
\text { MSA Bartik Demand Control }\end{array}$ & No & Yes & Yes & Yes \\
$\begin{array}{l}\text { MSA Population Growth Rate } \\
R^{2}\end{array}$ & No & No & Yes & Yes \\
\hline
\end{tabular}

Notes: See notes to Table B2. There are 932 observations in each column. 
Table B4. Testing the Age-Invariance Proposition: Industry-Level Log Employment Growth Response to Local House Price Growth, Annual Data from 1992 to 2018 (Omitting the Construction Sector)

Dependent Variable: Annual Log Employment Change at the MSA-Industry Level $\left(G R_{j m t}\right)$
(1) OLS
(2) OLS
(3) OLS
(4) IV

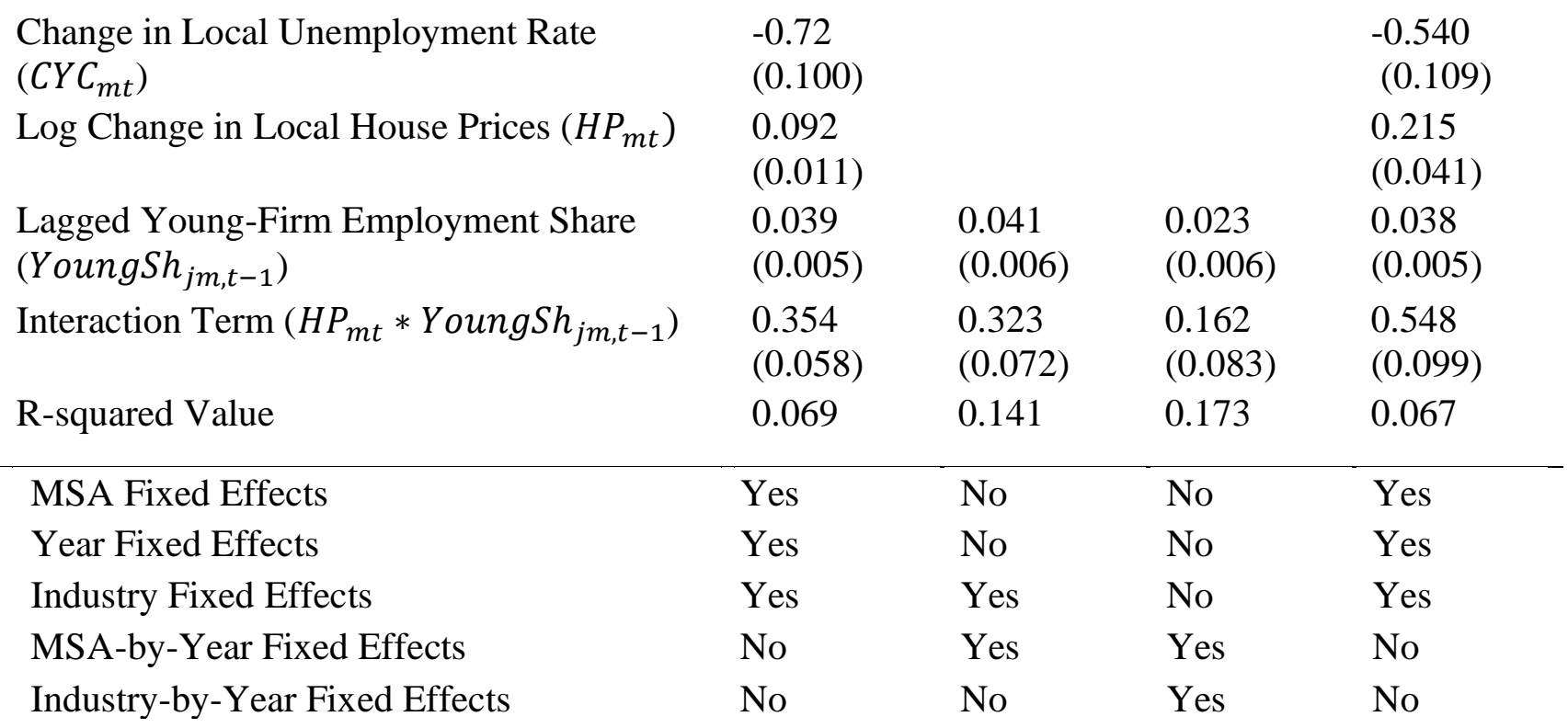

Notes: The sample, which covers 233 MSAs and 13 industries, contains 81,319 observations at the industry-MSA level from 1992 to 2018. It replicates Table 6 excluding the construction industry, 23. We drop cells with no employment. See text for list of industries. Column (4) instruments for $H P_{m t}$ and the interaction term using the IV approach used in Tables 1 and 2. Standard errors in parentheses, clustered at MSA level. 
Table B5. Quantifying the Departures from Age Invariance (Omitting the Construction Sector)

\section{A. Dispersion in Young-Firm Employment Shares Across Local Industries}

\begin{tabular}{llll}
\hline Industry-MSA Young-Firm Share & $1992-2018$ & Boom Period & Bust Period \\
90th Percentile & 1.442 & 1.441 & 1.378 \\
10th Percentile & 1.061 & 1.077 & 1.059 \\
Standard Deviation & 0.155 & 0.149 & 0.130 \\
90-10 Difference & 0.381 & 0.364 & 0.319
\end{tabular}

B. Dispersion in Annual MSA-Level Log House Price Changes

\begin{tabular}{llll}
\hline Log MSA House Price Change & $1992-2018$ & Boom Period & Bust Period \\
90th Percentile & 0.061 & 0.088 & 0.036 \\
10th Percentile & -0.044 & -0.002 & -0.123 \\
Standard Deviation & 0.054 & 0.043 & 0.077 \\
90-10 Difference & 0.105 & 0.090 & 0.159
\end{tabular}

C. Calculating the Departures from Age Invariance, Using $\hat{c}=\mathbf{0 . 5 4 8}$

\begin{tabular}{|c|c|c|c|c|}
\hline \multirow[b]{2}{*}{$H P(p)$ from Panel B } & \multicolumn{2}{|c|}{ Boom Period } & \multicolumn{2}{|c|}{ Bust Period } \\
\hline & P90 & P10 & P90 & $\mathrm{P} 10$ \\
\hline Average Annual Log Changes & 0.088 & -0.002 & 0.036 & -0.123 \\
\hline YoungSh ${ }^{90-10}$ from Panel A & \multicolumn{2}{|c|}{0.364} & \multicolumn{2}{|c|}{0.319} \\
\hline Response Differential Per Equation (8) & & & & \\
\hline Annual, Percentage Points & 1.7 & -0.0 & 0.6 & -2.2 \\
\hline Cumulative, Percentage Points & 7.2 & 0.3 & 1.9 & -6.3 \\
\hline
\end{tabular}

Notes: Panel $\mathrm{C}$ implements the calculation expressed in equation (8) in the main text. $\hat{\boldsymbol{c}}$ is the coefficient for the interaction term from column 4 of Table B4. Panels A and B report inputs to the calculation and related summary statistics. The Boom Period runs from 1998 to 2006, and the Bust Period runs from 2007 to 2010. 
Table B6. Testing the Age-Invariance Proposition with a Dynamic Specification: Industry-Level Log Employment Growth Responses to Local House Price Growth, Annual Data, 1992 to 2018

Reporting only the coefficients on the current and lagged interaction terms.

Dependent Variable: Annual Log Employment Change at the MSA-Industry Level $\left(G R_{j m t}\right)$
(1) OLS
(2) OLS
(3) OLS
(4) IV

\begin{tabular}{lllll} 
Interaction Term $\left(H P_{m t} *\right.$ YoungSh $\left._{j m, t-1}\right)$ & 0.892 & 0.872 & 0.603 & 1.379 \\
& $(0.075)$ & $(0.100)$ & $(0.112)$ & $(0.161)$ \\
Interaction Term $\left(H P_{m t-1} *\right.$ YoungSh $\left._{j m, t-1}\right)$ & -0.319 & -0.280 & -0.293 & -0.560 \\
& $(0.084)$ & $(0.101)$ & $(0.115)$ & $(0.159)$ \\
\hline MSA Fixed Effects & Yes & No & No & Yes \\
Year Fixed Effects & Yes & No & No & Yes \\
Industry Fixed Effects & Yes & Yes & No & Yes \\
MSA-by-Year Fixed Effects & No & Yes & Yes & No \\
Industry-by-Year Fixed Effects & No & No & Yes & No
\end{tabular}

Notes: See notes to Table 6. 


\section{Appendix C: Details Related to the CRA Data and How We Use Them}

CRA data provide bank-level information by local area and year on the volume of business loan originations to firms with less than $\$ 1$ million in revenue. We deflate nominal loan volumes by the same-year GDP implicit price deflator from the Bureau of Economic Analysis to obtain real small business loan volumes. As in GMN (2015), we roll up the bank level data to the bank holding company, using data sources from the FDIC and Federal Reserve call reports. We also use data from the Federal Reserve Bank of Chicago that tracks mergers and acquisitions, so that for any pair of years $t-1$ and $t$ we assign a bank to its owner in year $t$.

We measure the growth rate of small business loan volume for a given bank holding company in a particular MSA - what we call $g_{m j t}$ in equation (3) - using the symmetric growth rate measure in Davis, Haltiwanger and Schuh (1996). The DHS measure is equivalent to the log first difference up to a second-order Taylor Series approximation, but the DHS measure down weights outliers relative to log changes. As it turns out, DHS growth rates and log changes produce similar econometric results in Section IV.d.

One additional detail: We re-time the calendar-year $S B L_{i t}$ measure in equation (5) to align it with the March-to-March employment changes in the BDS. Specifically, in our regression analysis, the loan supply shock for MSA $m$ and year $t$ is $0.75 *$ Raw $S B L_{i t-1}+$ $0.25 *$ Raw $S B L_{i t}$. The correlation between this re-timed measure for year $t$ and the unadjusted measure for year $t-1$ is 0.95 for the MSA-level data used to produce Table 3. Replacing the retimed SBL measure for year $t$ with the corresponding lagged Raw SBL measure yields very similar results. 


\section{Appendix D: Alternative Approaches to IV Estimation of House Price Effects}

\section{D.1 Using Housing Price-Sensitivity Measures to Construct Instruments}

Recall that our main approach uses MSA-level housing supply elasticities from Saiz (2010) in constructing our instruments for MSA-level house price growth rates. As a robustness check, we follow Guren et al. (2021) and obtain housing supply elasticities as the inverse of MSA-level price-sensitivity estimates. Specifically, we fit the following regression specification by least squares to annual data from 1992 to 2018, pooled over MSAs and years:

$H P_{m t}=\sum_{m} \delta_{m} I_{m}+\sum_{s} \delta_{t r} I_{t r}+\psi_{m} H P_{d t}^{(m)}+\theta_{m} C Y C_{d t}+\chi_{m} C Y C_{m t}+X_{m t}^{\prime} \phi_{m}+\xi_{m t}$,

where $r$ indexes Census regions, $d$ indexes Census divisions, $H P_{m t}$ is the housing price growth

rate from year $t-l$ to year $t$ in MSA $m, H P_{d t}^{(m)}$ is the contemporaneous housing price growth rate in the Census division $d$ that contains MSA $m$, and the other variables and subscripts are defined as in the main text. We compute $H P_{d t}^{(m)}$ using the leave-out method, i.e., excluding MSA $m$.

The key coefficients of interest in (D.1) are the $\psi_{m}$ - the estimated sensitivity of housing prices in MSA $m$ to contemporaneous changes in housing prices in the rest of the same Census division. The idea is that a similar-size housing demand shift in the relevant Census division produces a larger price response in MSA $m$ when $m$ has a low housing supply elasticity. Thus, we interpret $\psi_{m}$ as inversely related to the local housing supply elasticity of MSA $m$. As Guren et al. stress, including controls in (D.1) helps address concerns about reverse causality and omitted variables. Thus, $X_{m t}$ includes the Bartik-type and population growth controls described in the main text. (D.1) also includes MSA fixed effects, time-varying cyclical controls for the MSA $m$ and Census division $d$, plus Census region-time fixed effects. There are four Census regions, indexed by $r$, each of which contains 2 or 3 Census divisions.

As Guren et al. (2021) discuss, $\psi_{m}$ is a proxy for the inverse of the housing supply elasticity. Figure B9 shows how the inverse of our estimated $\psi_{m}$ values correlate with the (log) Saiz elasticity measures. The two measures correlate strongly, but they also differ a good deal. The R-squared value for the regression line in Figure B9 is 0.13, the same as in Guren et al. We also find a similar pattern of discrepancies. For example, the inverse price-sensitivity estimates are lower than the Saiz elasticities in Detroit and Las Vegas.

\section{D.2 An Alternative Approach that Is Closer to Mian and Sufi (2011)}


Our main IV approach uses annual observations at the MSA level. We also implemented an alternative approach that more closely follows that of Mian and Sufi (2011). The alternative approach uses 932 observations on the average annual log changes in MSA-level data during four subperiods: a pre-boom period from 1992 to 1997, the housing market boom from 1998 to 2006, the bust from 2007 to 2010, and the post-bust period from 2011 to 2018. As seen in Figure B10, most MSAs experienced modest log price changes in the pre-boom and post-bust periods, strong price appreciation during the boom period, and sharp price declines during the bust.

We use these collapsed data to estimate the following statistical model:

$$
\begin{array}{ll}
Y_{m s}=\sum_{s} \lambda_{s} I_{s}+\sum_{m} \lambda_{m} I_{m}+\beta H P_{m s}+\varepsilon_{m s} & \text { (D.2) (Second stage) } \\
H P_{m s}=\sum_{m} \delta_{m} I_{m}+\sum_{s} \delta_{s} I_{s}+\sum_{s} I_{s} Z_{m}^{\prime} \gamma_{s}+\eta_{m s} & \text { (D.3) (First stage) }
\end{array}
$$

where $Y_{m s}$ is the annual average log change in the young-firm employment share for MSA $m$ during period $s, H P_{m s}$ is the contemporaneous annual average log change in the MSA's house price index, $I_{s}$ is a dummy for period $s, I_{m}$ is dummy for MSA $m, Z_{m}$ is a cubic polynomial in the Saiz housing supply elasticity, and $\lambda_{i}$ and $\delta_{i}$ are coefficients on dummy variables. The chief parameter of interest is $\beta$, the response of the change in the local young-firm employment share to the local house price change.

To identify $\beta$ we rely on the exclusion restrictions, $\mathrm{E}\left(I_{s} Z_{m}^{\prime}, \varepsilon_{m s}\right)=0$, which says that $I_{s} Z_{m}^{\prime}$ influences young-firm employment shares only through house price growth, conditional on period and MSA effects. In their papers, Mian and Sufi typically consider cross-sectional regressions in either the boom period or the bust period. Stacking the periods lets us control for MSA-specific trends, addressing concerns that these trends reflect other factors that happen to correlate with local housing supply elasticities, as argued by Davidoff (2016).

Table B2 reports regression results for specification (D.2) and (D.3) fit to the MSA-level data. We find a positive, statistically significant effect of local housing price growth on local young-firm activity shares. According to the IV estimates in column (3), which controls for common period effects and MSA fixed effects, an increase in local real housing prices of $10 \mathrm{log}$ points per year yields a gain of $1.4 \mathrm{log}$ points per year in the local young-firm employment share. IV estimates for $\beta$ are somewhat larger than the corresponding OLS estimates, in line with the view that measurement error in the local housing price indices produces some attenuation under OLS. F-tests show a very strong first stage, with test statistics well above 10. As seen in Figure 
B11, the IV-estimated relationship in Table B2 is similar in the boom and bust periods, and it is not driven by a few outliers.

Following the same logic as in the main text, we also consider specifications with additional local controls. See Table B3. We again find a strong positive impact of local housing price growth on young-firm activity shares for the IV results. Conditioning on all three additional controls in Column (4), an increase in local real housing prices of 10 log points per year raises the local young-firm employment share by 1.31 log points per year. ${ }^{20}$ This effect is statistically significant at the 5 percent level, and an F-test again provides strong evidence against the hypothesis of weak instruments.

\section{D.3 A Dynamic Extension to Specification (7)}

We now extend (7) to include the lagged main effect for local house price changes and its interaction with the young-firm employment share in the local industry. This dynamic specification allows the effects of interest to unfold over time, possibly attenuating or amplifying the contemporaneous effect captured by coefficient, $c$, in (7). Accordingly, Appendix Table B6 reports the coefficients on the contemporaneous and lagged interaction terms in the dynamic extension to (7). The other coefficients are similar to the ones reported in Table 6.

The dynamic extension yields two additional results: First, the contemporaneous localindustry response to an increase in local house prices now rises more steeply with the local industry's young-firm share. For example, the coefficient on the contemporaneous interaction term is 1.38 in column (4) of Table B6, as compared to 0.95 in Table 6. Second, the dynamic extension implies that this impact effect is amplified in the following year. To see this point, note first that local house price changes are highly persistent, with an AR1 coefficient of 0.73, conditional on MSA fixed effects. Combining this AR coefficient with the results in Column (4) of Table B6, the effect associated with the interaction terms one year after a local house price increase is $(1.38 * 0.73)-0.56=0.45$. That is, the effect of local house price gains in period $t$ on local industry employment growth in $t$ with the local industry's young-firm share, and it rises even further in period $t+1$. The average cumulative effect equals $1.38+0.45=1.83$, which is nearly twice as large as the $\hat{\boldsymbol{c}}=0.95$ value yielded by the static specification (7). Thus, the dynamic extension to (7) implies that local industry employment responses to local house price

\footnotetext{
${ }^{20}$ Because of the dotcom bust, San Francisco stands out as an MSA with a large drop in the young-firm employment share from 2002 to 2006, even as local housing prices appreciated. In unreported results that exclude data for San Francisco, the estimate of $\beta$ corresponding to Column (4) in Table B2 is .154, somewhat larger than the full-sample estimate.
} 
changes vary with the firm-age structure of employment in the local industry by nearly twice as much as indicated by the calculations in Panel C of Table 7. 